\title{
Design and Development of a Macrocyclic Series Targeting Phosphoinositide 3-Kinase $\delta$
}

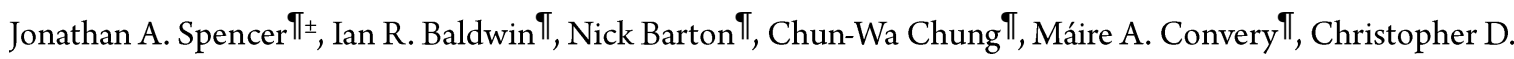

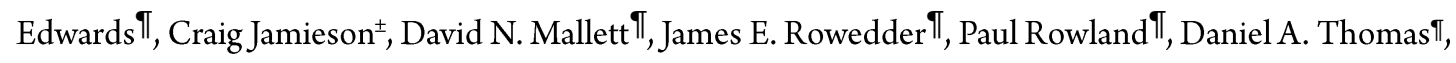 \\ Charlotte J. Hardy T* $^{*}$
}

TGSK Medicines Research Centre, Gunnels Wood Road, Stevenage, SG1 2NY, U.K.

${ }^{ \pm}$University of Strathclyde, Department of Pure and Applied Chemistry, 295 Cathedral Street, Glasgow G1 1XL, U.K.

\section{Contents}

General Experimental . .2

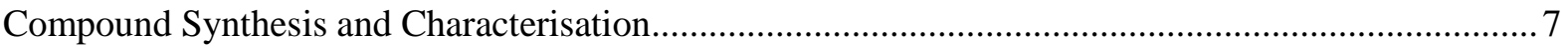

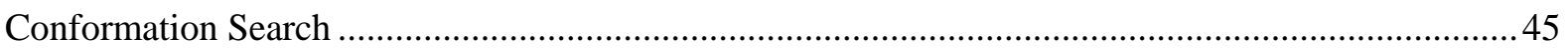

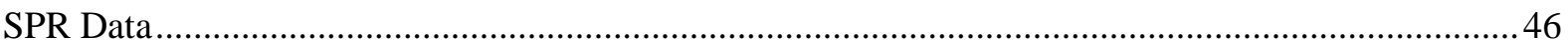

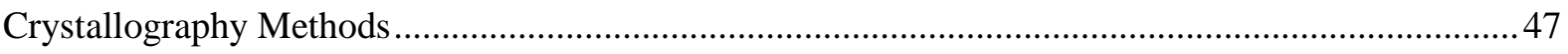




\section{General Experimental}

All solvents were of analytical grade, purchased from Sigma Aldrich in anhydrous form.

Unless otherwise stated reagents were purchased from regular suppliers, such as Sigma Aldrich or Fluorochem and used without further purification. Schwartz's Reagent was purchased from Strem Chemicals and used without further purification.

Thin layer chromatography (TLC) was carried out using plastic-backed precoated silica plates (particle size $0.2 \mathrm{~mm}$ ). Spots were visualized by ultraviolet (UV) light $\left(\lambda_{\max }=254 \mathrm{~nm}\right.$ or $365 \mathrm{~nm}$ ) and then stained with potassium permanganate solution followed by gentle heating.

Silica gel chromatography was carried out using the Teledyne ISCO CombiFlash ${ }^{\circledR} \mathrm{Rf}+$ apparatus with RediSep ${ }^{\circledR}$ silica cartridges or RediSep ${ }^{\circledR} \mathrm{C}_{18}$ reverse phase cartridges.

Infrared spectra were recorded on a Perkin Elmer Spectrum One Fourier Transform spectrometer, with samples used neat. Only selected absorptions are reported and quoted in reciprocal centimetres $\left(\mathrm{cm}^{-1}\right)$.

${ }^{1}$ H NMR were recorded on a Bruker AVI (400 MHz) or Bruker Nano (400 MHz) spectrometer. Chemical shifts $(\delta)$ are quoted in ppm relative to the residual solvent peak. Coupling constants $(J)$ are given in $\mathrm{Hz}$ to the nearest $0.1 \mathrm{~Hz}$ (although are only accurate to $+/-0.5 \mathrm{~Hz}$ ). The following abbreviations are used: s, singlet; d, doublet; t, triplet; q, quartet; dd, doublet doublet; m, multiplet; br., broad. Diastereoisomers were assigned by analysis of ${ }^{3} \mathrm{~J}_{\mathrm{H}-\mathrm{H}}$ coupling of cyclopropyl ring protons by comparison with literature where possible, other peaks were then assigned by comparison of integrals. Peaks assigned to common solvents such as cyclohexane and water are not reported in the experimental.

${ }^{13} \mathbf{C}$ NMR were recorded on a Bruker AVI (acquired at $101 \mathrm{MHz}$ ) spectrometer. Chemical shifts $(\delta)$ are quoted in ppm relative to the residual solvent peak. Peaks assigned to common solvents such as cyclohexane are not reported in the experimental.

High resolution mass spectra were recorded using a Micromass Q-Tof Ultima hybrid quadrupole time-of-flight mass spectrometer equipped with a Z-spray (ESI) interface, over a mass range of 100$1100 \mathrm{Da}$, with a scan time of $0.9 \mathrm{~s}$ and an interscan delay of $0.1 \mathrm{~s}$. Reserpine was used as the external mass calibrant $\left([\mathrm{M}+\mathrm{H}]^{+}=609.2812 \mathrm{Da}\right)$. The Q-Tof Ultima mass spectrometer was operated in $\mathrm{W}$ reflection mode to give a resolution (FWHM) of 16000-20000. Ionisation was achieved with a spray voltage of $3.2 \mathrm{kV}$, a cone voltage of $100 \mathrm{~V}$, with cone and desolvation gas flows of $10-20$ and $600 \mathrm{~L} \mathrm{~h}^{-}$

${ }^{1}$ respectively. The elemental composition was calculated using MassLynx v4.1 for the $[\mathrm{M}+\mathrm{H}]^{+}$.

LCMS Method A: The HPLC analysis was conducted on an Acquity UPLC BEH $\mathrm{C}_{18}$ column $(1.7 \mu \mathrm{m}$, $2.1 \mathrm{~mm}$ x $50 \mathrm{~mm}$ ) at $40{ }^{\circ} \mathrm{C}$. 
Solvent $\mathrm{A}=0.1 \% \mathrm{v} / \mathrm{v}$ Formic Acid in water

Solvent $\mathrm{B}=0.1 \% \mathrm{v} / \mathrm{v}$ Formic acid in acetonitrile

The gradient employed was:

\begin{tabular}{|l|l|l|l|}
\hline Time (min) & Flow Rate (mL/min) & $\%$ A & $\%$ B \\
\hline \hline 0 & 1 & 97 & 3 \\
\hline 1.5 & 1 & 0 & 100 \\
\hline 1.9 & 1 & 0 & 100 \\
\hline 2 & 1 & 97 & 3 \\
\hline
\end{tabular}

The UV detection was based on an averaged signal from wavelength of $210 \mathrm{~nm}$ to $350 \mathrm{~nm}$ and mass spectra were recorded on a mass spectrometer using alternate-scan positive and negative mode electrospray ionization.

LCMS Method B: The HPLC analysis was conducted on an Acquity UPLC BEH $\mathrm{C}_{18}$ column $(1.7 \mu \mathrm{m}$, $2.1 \mathrm{~mm} \times 50 \mathrm{~mm})$ at $40{ }^{\circ} \mathrm{C}$.

Solvent $\mathrm{A}=10 \mathrm{mM}$ Ammonium Bicarbonate in water adjusted to $\mathrm{pH} 10$ with ammonia solution

Solvent $\mathrm{B}=$ Acetonitrile

The gradient employed was:

\begin{tabular}{|l|l|l|l|}
\hline Time (min) & Flow Rate (mL/min) & $\%$ A & $\%$ B \\
\hline \hline 0 & 1 & 93 & 7 \\
\hline 1.5 & 1 & 3 & 97 \\
\hline 1.9 & 1 & 3 & 97 \\
\hline 2 & 1 & 0 & 100 \\
\hline
\end{tabular}

The UV detection was based on an averaged signal from wavelength of $210 \mathrm{~nm}$ to $350 \mathrm{~nm}$ and mass spectra were recorded on a mass spectrometer using alternate-scan positive and negative mode electrospray ionization. 
LCMS Method C: The HPLC analysis was conducted on an Xbridge C18 $(2.5 \mu \mathrm{m}, 4.6 \mathrm{~mm}$ x $50 \mathrm{~mm})$ at $35^{\circ} \mathrm{C}$.

Solvent $\mathrm{A}=5 \mathrm{mM}$ Ammonium Acetate in water

Solvent $\mathrm{B}=$ Acetonitrile

The gradient employed was:

\begin{tabular}{|l|l|l|l|}
\hline Time (min) & Flow Rate (mL/min) & \% A & $\%$ B \\
\hline \hline 0 & 1.3 & 95 & 5 \\
\hline 0.5 & 1.3 & 95 & 5 \\
\hline 1.0 & 1.3 & 85 & 15 \\
\hline 3.3 & 1.3 & 2 & 98 \\
\hline 5.2 & 1.3 & 2 & 98 \\
\hline 5.5 & 1.3 & 95 & 5 \\
\hline 6.0 & 1.3 & 95 & 5 \\
\hline
\end{tabular}

LCMS Method D: The HPLC analysis was conducted on an Acquity BEH-C18 column $(1.7 \mu \mathrm{m}, 2.1$ $\mathrm{mm} \times 50 \mathrm{~mm})$ at $35^{\circ} \mathrm{C}$.

Solvent $\mathrm{A}=5 \mathrm{mM}$ Ammonium Acetate in water

Solvent $\mathrm{B}=$ Acetonitrile

The gradient employed was:

\begin{tabular}{|l|l|l|l|}
\hline Time (min) & Flow Rate (mL/min) & \% A & $\%$ B \\
\hline \hline 0.01 & 0.6 & 97 & 3 \\
\hline 0.4 & 0.6 & 97 & 3 \\
\hline 3.2 & 0.6 & 2 & 98 \\
\hline 4.8 & 0.6 & 2 & 98 \\
\hline 4.9 & 0.6 & 97 & 3 \\
\hline
\end{tabular}




\begin{tabular}{|l|l|l|l|}
\hline 5.0 & 0.6 & 97 & 3 \\
\hline
\end{tabular}

LCMS Method E: The HPLC analysis was conducted on an Acquity BEH-C18 column $(1.7 \mu \mathrm{m}, 2.1$ $\mathrm{mm} \times 50 \mathrm{~mm})$ at $35^{\circ} \mathrm{C}$.

Solvent $\mathrm{A}=0.1 \%$ Formic acid in water

Solvent $\mathrm{B}=0.1 \%$ Formic acid in acetonitrile

The gradient employed was:

\begin{tabular}{|l|l|l|l|}
\hline Time (min) & Flow Rate (mL/min) & \% A & $\%$ B \\
\hline \hline 0 & 0.6 & 97 & 3 \\
\hline 0.4 & 0.6 & 97 & 3 \\
\hline 3.2 & 0.6 & 2 & 98 \\
\hline 3.8 & 0.6 & 2 & 98 \\
\hline 4.2 & 0.6 & 97 & 3 \\
\hline 4.5 & 0.6 & 97 & 3 \\
\hline
\end{tabular}

LCMS Method F: The HPLC analysis was conducted on an Phenomenex $(3.0 \mu \mathrm{m}, 4.6 \mathrm{~mm}$ x $50 \mathrm{~mm})$ at $35^{\circ} \mathrm{C}$.

Solvent $\mathrm{A}=5 \mathrm{mM}$ Ammonium bicarbonate in water at $\mathrm{pH} 10$

Solvent $\mathrm{B}=$ Acetonitrile

The gradient employed was:

\begin{tabular}{|l|l|l|l|}
\hline Time (min) & Flow Rate (mL/min) & \% A & $\%$ B \\
\hline \hline 0 & 1.3 & 95 & 5 \\
\hline 0.5 & 1.3 & 95 & 5 \\
\hline 1.5 & 1.3 & 85 & 15 \\
\hline 4.5 & 1.3 & 2 & 98 \\
\hline 6.5 & 1.3 & 2 & 98 \\
\hline
\end{tabular}




\begin{tabular}{|l|l|l|l|}
\hline 7.0 & 1.3 & 95 & 5 \\
\hline 7.5 & 1.3 & 95 & 5 \\
\hline
\end{tabular}

Mass directed auto preparation (MDAP). Mass-directed automated purification was carried out using an $\mathrm{H}_{2} \mathrm{Os} \mathrm{ZQ}$ MS using alternate-scan positive and negative electrospray and a summed UV wavelength of 210-350 nm. Two liquid phase methods were used:

Formic - Sunfire C18 column (100 mm x $19 \mathrm{~mm}, 5 \mu \mathrm{m}$ packing diameter, $20 \mathrm{~mL} / \mathrm{min}$ flow rate) or Sunfire C18 column ( $150 \mathrm{~mm}$ x $30 \mathrm{~mm}, 5 \mu \mathrm{m}$ packing diameter, $40 \mathrm{~mL} / \mathrm{min}$ flow rate). Gradient elution at ambient temperature with the mobile phases as $(\mathrm{A}) \mathrm{H}_{2} \mathrm{O}$ containing $0.1 \%$ volume/volume (v/v) formic acid and (B) acetonitrile containing $0.1 \%(\mathrm{v} / \mathrm{v})$ formic acid.

High pH - Xbridge C18 column (100 mm x $19 \mathrm{~mm}, 5 \mu \mathrm{m}$ packing diameter, $20 \mathrm{~mL} / \mathrm{min}$ flow rate) or Xbridge C18 column ( $150 \mathrm{~mm}$ x $30 \mathrm{~mm}, 5 \mu \mathrm{m}$ packing diameter, $40 \mathrm{~mL} / \mathrm{min}$ flow rate). Gradient elution at ambient temperature with the mobile phases as (A) $10 \mathrm{mM}$ aqueous ammonium bicarbonate solution, adjusted to $\mathrm{pH} 10$ with $0.88 \mathrm{M}$ aqueous ammonia and (B) acetonitrile. 


\section{Compound Synthesis and Characterisation}

methyl 3,4-dihydro-2H-benzo[b][1,4]oxazine-6-carboxylate, 27<smiles>COC(=O)c1ccc2c(c1)NCCO2</smiles>

To a solution of methyl 3-amino-4-hydroxybenzoate $(5.0 \mathrm{~g}, 29.9 \mathrm{mmol})$ and potassium carbonate (16.5 $\mathrm{g}, 120 \mathrm{mmol})$ in DMF (100 mL), was added 1,2-dibromoethane (10.3 mL, $120 \mathrm{mmol})$. the mixture was then heated at $70{ }^{\circ} \mathrm{C}$ for $18 \mathrm{~h}$. The reaction mixture was then allowed to cool to room temperature and was diluted with $5 \%$ aqueous lithium chloride solution $(200 \mathrm{~mL})$ and extracted with dichloromethane $(3 \times 100 \mathrm{~mL}$ ). The organic portions were combined, dried over a hydrophobic frit and the solvent removed in vacuo. The residue was loaded in minimal dichloromethane and purified by column chromatography on silica using a $0-100 \%$ ethyl acetate/cyclohexane gradient. The appropriate fractions were combined and evaporated in vacuo to give the title compound $(4.9 \mathrm{~g}, 85 \%)$ as a yellow solid. ${ }^{1} \mathrm{H}$ NMR (400 MHz, $\left.\mathrm{CDCl}_{3}\right) \delta$ ppm 3.43-3.49 (m, 2 H), 3.88 (s, $\left.3 \mathrm{H}\right), 4.25-4.42$ (m, $2 \mathrm{H}$ ), 6.81 (d, $J=8.3$ $\mathrm{Hz}, 1 \mathrm{H}), 7.32(\mathrm{~d}, J=2.1 \mathrm{~Hz}, 1 \mathrm{H}), 7.39(\mathrm{dd}, J=8.4,2.1 \mathrm{~Hz}, 1 \mathrm{H}) ; \mathrm{LCMS}$ (Method A): $\mathrm{MH}^{+}$ $\left(\mathrm{C}_{10} \mathrm{H}_{12} \mathrm{NO}_{3}\right)$ mass required: 194 mass found: 194, Rt 0.83 min, $100 \%$ by UV.

\section{3-(benzylthio)-5-bromo-2-methoxypyridine, 34}<smiles>COc1ncc(Br)cc1SCc1ccccc1</smiles>

To a suspension of sodium hydride $(0.49 \mathrm{~g}, 20.6 \mathrm{mmol})$, in dry DMF $(25 \mathrm{~mL})$ stirred under nitrogen at $0{ }^{\circ} \mathrm{C}$, was added a solution of 3,5-dibromo-2-methoxypyridine $(5 \mathrm{~g}, 18.7 \mathrm{mmol})$, in dry DMF $(25 \mathrm{~mL})$ drop wise over $5 \mathrm{~min}$. Then, phenylmethanethiol $(2.327 \mathrm{~g}, 18.73 \mathrm{mmol})$ was added to the reaction mixture drop wise over $15 \mathrm{~min}$ at $0{ }^{\circ} \mathrm{C}$. Then reaction mixture was allowed to warm to room temperature and was stirred for $5 \mathrm{~h}$. The reaction mixture was then diluted with water $(150 \mathrm{~mL})$ and ethyl acetate $(50 \mathrm{~mL})$, the organic layer was seperated and the aqueous layer was extracted with further ethyl acetate $(2 \times 50 \mathrm{~mL})$. The combined organic layers were washed with brine $(50 \mathrm{~mL})$, dried over anhydrous sodium sulfate and concentrated under reduced pressure to give crude product. The residue was then purified by column chromatography on silica using $2 \%$ ethyl acetate in hexane. The appropriate fractions were combined and concentrated under reduced pressure. The residue was then triturated with $n$-pentane to afford the title compound (2.6 g, $44 \%$ yield) as a white solid. ${ }^{1} \mathrm{H}$ NMR (400 MHz, DMSO$\left.d_{6}\right) \delta \mathrm{ppm} 3.89(\mathrm{~s}, 3 \mathrm{H}), 4.28$ (s, $\left.2 \mathrm{H}\right)$, 7.23-7.29 (m, $\left.1 \mathrm{H}\right)$, 7.30-7.36 (m, $\left.2 \mathrm{H}\right), 7.37-7.42$ (m, $\left.2 \mathrm{H}\right), 7.76$ 
$(\mathrm{d}, J=2.3 \mathrm{~Hz}, 1 \mathrm{H}), 8.03(\mathrm{~d}, J=2.3 \mathrm{~Hz}, 1 \mathrm{H}) ; \mathrm{LCMS}$ (Method D): $\mathrm{MH}^{+}\left(\mathrm{C}_{13} \mathrm{H}_{13}{ }^{79} \mathrm{BrNOS}\right.$ ) mass required: 310 mass found: 310 , Rt $2.94 \mathrm{~min}, 98 \%$ by UV.

\section{5-bromo-2-methoxy- $N$-methylpyridine-3-sulfonamide, 35}<smiles>CNS(=O)(=O)c1cc(Br)cnc1OC</smiles>

To a stirred solution of 3-(benzylthio)-5-bromo-2-methoxypyridine ( $23 \mathrm{~g}, 74.1 \mathrm{mmol}$ ) in acetic acid $(230 \mathrm{~mL})$ and Water $(77 \mathrm{~mL})$, was added solid $\mathrm{N}$-chlorosuccinamide $(38.6 \mathrm{~g}, 289 \mathrm{mmol})$ portionwise. The reaction mixture was stirred at $\mathrm{rt}$ for $3 \mathrm{hrs}$. The reaction mixture was evaporated under reduced pressure to give pale brown liquid $(35 \mathrm{~g})$. The organic phase was diluted with water $(500 \mathrm{~mL})$ and extracted into EtOAc ( $3 \mathrm{x} 400 \mathrm{~mL})$ and the combined organics were washed with water $250 \mathrm{~mL}$, saturated brine $250 \mathrm{~mL}$, dried over sodium sulphate and evaporated in vacuo to afford 5-bromo-2methoxypyridine-3-sulfonylchloride (20 g, $69.8 \mathrm{mmol}, 94 \%$ yield) as a yellow liquid.

To a suspension of 5-bromo-2-chloropyridine-3-sulfonyl chloride ( $6.0 \mathrm{~g}, 20.9 \mathrm{mmol})$ in tetrahydrofuran $(30 \mathrm{~mL})$, stirred at $0{ }^{\circ} \mathrm{C}$ was added methanamine $(31.4 \mathrm{~mL}, 62.8 \mathrm{mmol}, 2 \mathrm{M}$ solution). The reaction was then stirred at r.t for $16 \mathrm{hrs}$. The reaction mixture was concentrated under reduced pressure and the residue was purified by column chromatography on silica using $0-20 \%$ ethyl acetate in hexane. The appropriate fractions were combined and concentrated under reduced pressure to give the title compound (3.0 g, 38\%) as a yellow solid. ${ }^{1} \mathrm{H}$ NMR (400 MHz, DMSO- $\left.d_{6}\right) \delta \mathrm{ppm} 2.49(\mathrm{~d}, J=4.4 \mathrm{~Hz}, 3$ H), 3.99 (s, $3 \mathrm{H}), 7.53$ (d, $J=4.4 \mathrm{~Hz}, 1 \mathrm{H}), 8.16$ (d, $J=2.6 \mathrm{~Hz}, 1 \mathrm{H}), 8.56$ (d, $J=2.6 \mathrm{~Hz}, 1 \mathrm{H})$; LCMS (Method D): $\mathrm{MH}^{+}\left(\mathrm{C}_{7} \mathrm{H}_{10}{ }^{81} \mathrm{BrN}_{2} \mathrm{O}_{3} \mathrm{~S}\right)$ mass required: 283 mass found: 283, Rt $1.90 \mathrm{~min}, 99 \%$ by $\mathrm{UV}$.

methyl 4-(6-methoxy-5-( $N$-methylsulfamoyl)pyridin-3-yl)-3,4-dihydro-2H-benzo $[b][1,4]$ oxazine6-carboxylate, 36<smiles>CNS(=O)(=O)c1cc(N2CCOc3ccc(C(=O)OC)cc32)cnc1OC</smiles>

To a degassed solution of 5-bromo-2-methoxy- $N$-methylpyridine-3-sulfonamide (1.2 g, $4.4 \mathrm{mmol}$ ), methyl 3,4-dihydro-2H-benzo[b][1,4]oxazine-6-carboxylate $(0.7 \mathrm{~g}, 3.6 \mathrm{mmol})$ and dicyclohexyl $(2 ', 6$ diisopropoxy-[1,1'-biphenyl]-2-yl)phosphine $(0.68 \mathrm{~g}, 1.4 \mathrm{mmol})$ in 1,4-dioxane $(30 \mathrm{~mL})$ stirred under argon at room temperature was added cesium carbonate $(3.54 \mathrm{~g}, 10.87 \mathrm{mmol})$ and $\operatorname{Pd}_{2}(\mathrm{dba})_{3}(0.66 \mathrm{~g}$, 
$0.73 \mathrm{mmol}$ ). The reaction vessel was sealed and mixture was stirred at $100{ }^{\circ} \mathrm{C}$ for $48 \mathrm{~h}$. The reaction mixture was then diluted with water $(500 \mathrm{~mL})$ and extracted with ethyl acetate $(2 \times 50 \mathrm{~mL})$. The organic portions were combined, dried over anhydrous sodium sulfate and concentrated under reduced pressure to yield a brown gum $(3.0 \mathrm{~g})$. This was then purified by column chromatography on silica using a 0 $100 \%$ ethyl acetate/hexane gradient. The appropriate fractions were combined and concentrated under reduced pressure to yield the title compound $(200 \mathrm{mg}, 13 \%)$ as a yellow solid. ${ }^{1} \mathrm{H}$ NMR (400 MHz, $\left.\mathrm{CDCl}_{3}\right) \delta \mathrm{ppm} 2.71(\mathrm{~d}, J=5.3 \mathrm{~Hz}, 3 \mathrm{H}), 3.66-3.71(\mathrm{~m}, 2 \mathrm{H}), 3.80(\mathrm{~s}, 3 \mathrm{H}), 4.13$ (s, $\left.3 \mathrm{H}\right), 4.37-4.41$ (m, $2 \mathrm{H}), 4.86(\mathrm{q}, J=5.3 \mathrm{~Hz}, 1 \mathrm{H}), 6.91(\mathrm{~d}, J=8.3 \mathrm{~Hz}, 1 \mathrm{H}), 7.34(\mathrm{~d}, J=2.0 \mathrm{~Hz}, 1 \mathrm{H}), 7.50$ (dd, $J=8.6$, $2.0 \mathrm{~Hz}, 1 \mathrm{H}), 8.08(\mathrm{~d}, J=2.8 \mathrm{~Hz}, 1 \mathrm{H}), 8.28(\mathrm{~d}, J=2.6 \mathrm{~Hz}, 1 \mathrm{H}) ; \mathrm{LCMS}$ (Method E): $\mathrm{MH}^{+}\left(\mathrm{C}_{17} \mathrm{H}_{20} \mathrm{~N}_{3} \mathrm{O}_{6} \mathrm{~S}\right.$ ) mass required: 394 mass found: 394, Rt $2.20 \mathrm{~min}, 92 \%$ by UV.

\section{4-(6-methoxy-5-( $N$-methylsulfamoyl)pyridin-3-yl)- $N, N$-dimethyl-3,4-dihydro-2H-} benzo $[b][1,4]$ oxazine-6-carboxamide, 12<smiles>CNS(=O)(=O)c1cc(N2CCOc3ccc(C(=O)N(C)C)cc32)cnc1OC</smiles>

To a solution of methyl 4-(6-methoxy-5-(N-methylsulfamoyl)pyridin-3-yl)-3,4-dihydro-2 $\mathrm{H}$ benzo[b][1,4] oxazine-6-carboxylate $(200 \mathrm{mg}, 0.51 \mathrm{mmol})$ in THF $(7.0 \mathrm{~mL})$, was added a solution of lithium hydroxide $(49 \mathrm{mg}, 2.0 \mathrm{mmol})$ dissovled in water $(3.5 \mathrm{~mL})$. The reaction mixture was stirred at room temperature for $5 \mathrm{~h}$. The reaction mixture was diluted with water $(10 \mathrm{~mL})$ and washed with EtOAc $(2 \times 10 \mathrm{~mL})$. The aqueous layer was seperated, acidified with $1 \mathrm{M} \mathrm{HCl}$ to $\mathrm{pH} 4$ and extracted with ethyl acetate $(2 \times 10 \mathrm{~mL})$. The organic layers were combined, dried over anhydrous sodium sulfate and concentrated under vacuum to yield 4-(6-methoxy-5-( $N$-methylsulfamoyl)pyridin-3-yl)-3,4-dihydro$2 H$-benzo[b][1,4]oxazine-6-carboxylic acid $(150 \mathrm{mg}, 0.31 \mathrm{mmol}, 61 \%$ yield) as a yellow solid. To a solution of yellow solid (150 mg, $0.31 \mathrm{mmol})$, dimethylaminehydrochloride (30 mg, $0.38 \mathrm{mmol})$ and HATU (143 mg, $0.375 \mathrm{mmol})$ in DCM (10 mL) stirred under nitrogen at room temperature, was added DIPEA $(0.14 \mathrm{~mL}, 0.78 \mathrm{mmol})$. The reaction mixture was stirred at $\mathrm{rt}$ for $16 \mathrm{~h}$ and was then concentrated under reduced pressure. The residue obtained was dissolved in ethyl acetate $(15 \mathrm{~mL})$ and washed with water $(10 \mathrm{~mL})$, saturated sodium bicarbonate solution $(10 \mathrm{~mL})$ and brine solution $(10 \mathrm{~mL})$. The organic layer was seperated, dried over anhydrous sodium sulfate and concentrated under reduced pressure to afford a yellow gum (180 mg). This was purified by preparative TLC on GF 254 silica coated glass plates and $70 \%$ ethyl acetate in hexane to yield an off-white solid $(110 \mathrm{mg})$. This was recrystalised from ethanol ( $2 \mathrm{~mL})$, filtered and dried under vacuum to yield the title compound ( $85 \mathrm{mg}, 64 \%$ yield) 
as white solid. ${ }^{1} \mathrm{H} \mathrm{NMR}\left(400 \mathrm{MHz}, \mathrm{CDCl}_{3}\right) \delta \mathrm{ppm} 2.69(\mathrm{~d}, J=5.3 \mathrm{~Hz}, 3 \mathrm{H}), 3.00(\mathrm{~s}, 6 \mathrm{H}), 3.66-3.70$ $(\mathrm{m}, 2 \mathrm{H}), 4.11(\mathrm{~s}, 3 \mathrm{H}), 4.33-4.37(\mathrm{~m}, 2 \mathrm{H}), 4.87(\mathrm{q}, J=5.2 \mathrm{~Hz}, 1 \mathrm{H}), 6.76(\mathrm{~d}, J=1.5 \mathrm{~Hz}, 1 \mathrm{H}), 6.85$ $(\mathrm{dd}, J=8.3,1.6 \mathrm{~Hz}, 1 \mathrm{H}), 6.89(\mathrm{~d}, J=8.3 \mathrm{~Hz}, 1 \mathrm{H}), 8.07(\mathrm{~d}, J=2.6 \mathrm{~Hz}, 1 \mathrm{H}), 8.28(\mathrm{~d}, J=2.6 \mathrm{~Hz}, 1$ $\mathrm{H})$; LCMS (Method A): $\mathrm{MH}^{+}\left(\mathrm{C}_{18} \mathrm{H}_{23} \mathrm{~N}_{4} \mathrm{O}_{5} \mathrm{~S}\right)$ mass required: 407 mass found: 407, Rt 0.79 min, $100 \%$ by UV.

\section{5-(6-((dimethylamino)methyl)-2H-benzo $[b][1,4]$ oxazin-4(3H)-yl)-2-methoxy- $N$-methylpyridine-}

\section{3-sulfonamide, 2}<smiles>CNS(=O)(=O)c1cc(N2CCOc3ccc(CN(C)C)cc32)cnc1OC</smiles>

To a solution of 4-(6-methoxy-5-(N-methylsulfamoyl)pyridin-3-yl)- $\mathrm{N}, \mathrm{N}$-dimethyl-3,4-dihydro- $2 \mathrm{H}$ benzo[b][1,4] oxazine-6-carboxamide $(60 \mathrm{mg}, 0.148 \mathrm{mmol})$ in THF $(10 \mathrm{~mL})$ stirred under nitrogen at $65^{\circ} \mathrm{C}$ was added borane dimethyl sulfide complex (1M in THF, $0.44 \mathrm{~mL}, 0.44 \mathrm{mmol}$ ) dropwise over 2 min. The reaction mixture was stirred at $65{ }^{\circ} \mathrm{C}$ for $3 \mathrm{~h}$. Methanol $(5 \mathrm{~mL})$ was added and the mixture refluxed for $12 \mathrm{~h}$. The reaction mixture was then concentrated under reduced pressure, the residue dissolved in ethyl acetate $(10 \mathrm{~mL})$ and washed with water $(2 \times 10 \mathrm{~mL})$. The organic layer was then separated, dried over anhydrous sodium sulfate and concentrated under reduced pressure to afford a yellow gum. The compound was then purified using a preparative TLC on GF 254 silica coated glass plates using $70 \%$ ethyl acetate in hexane to yield the title compound $(18 \mathrm{mg}, 31 \%)$ as an off-white solid. ${ }^{1} \mathrm{H}$ NMR (400 MHz, CDCl3) $\delta$ ppm 2.21 (br. s., 6 H), 2.71 (d, $J=5.3$ Hz, 3 H), 3.29 (br. s., 2 H), 3.65 3.69 (m, 2 H), 4.11 (s, 3 H), 4.27-4.32 (m, 2 H), 6.69-6.75 (m, 2 H), 6.85 (d, J = 8.1 Hz, 1 H), 8.09 (d, $J=2.6 \mathrm{~Hz}, 1 \mathrm{H}), 8.25$ (d, $J=2.6 \mathrm{~Hz}, 1 \mathrm{H})$; LCMS (Method A): $\mathrm{MH}^{+}\left(\mathrm{C}_{18} \mathrm{H}_{25} \mathrm{~N}_{4} \mathrm{O}_{4} \mathrm{~S}\right.$ ) mass required: 393 mass found: 393, Rt $0.56 \mathrm{~min}, 95 \%$ by UV.

4-(6-methoxy-5-( $N$-methylsulfamoyl)pyridin-3-yl)- $N$-methyl-3,4-dihydro-2Hbenzo $[b][1,4]$ oxazine-6-carboxamide, 9<smiles>CNC(=O)c1ccc2c(c1)N(c1cnc(OC)c(S(=O)(=O)NC)c1)CCO2</smiles> 
To a solution of methyl 4-(6-methoxy-5-( $N$-methylsulfamoyl)pyridin-3-yl)-3,4-dihydro-2Hbenzo[b][1,4] oxazine-6-carboxylate $(1.2 \mathrm{~g}, 3.1 \mathrm{mmol})$ in THF $(26 \mathrm{~mL})$ and water $(13 \mathrm{~mL})$ stirred under nitrogen at room temperature was added lithium hydroxide $(0.22 \mathrm{~g}, 9.2 \mathrm{mmol})$ in in one charge. The reaction was stirred for $16 \mathrm{hr}$. The mixture was then diluted with water $(10 \mathrm{~mL})$ and washed with ethyl acetate $(2 \times 20 \mathrm{~mL})$. The aqueous layer was seperated, acidified with $1 \mathrm{M} \mathrm{HCl}$ to $\mathrm{pH} 4$ and then extracted with ethyl acetate $(2 \times 25 \mathrm{~mL})$. The combined organic layers were seperated, dried over anhydrous sodium sulfate and concentrated under reduced pressure to yield an off-white solid (700 mg). To a solution of off-white solid (200 mg, $0.53 \mathrm{mmol})$, HATU (301 mg, $0.79 \mathrm{mmol}$ )and DIPEA (0.28 mL, $1.58 \mathrm{mmol})$ in $\mathrm{DCM}(10 \mathrm{~mL})$ stirred under nitrogen at $0^{\circ} \mathrm{C}$, was added methylamine hydrochloride (33 $\mathrm{mg}, 0.79 \mathrm{mmol})$. The reaction was then stirred at room temperature for $16 \mathrm{~h}$. The mixture was diluted with DCM $(10 \mathrm{ml})$ and washed with saturated brine $(10 \mathrm{~mL})$ and water $(10 \mathrm{~mL})$. The organic phase was dried over sodium sulfate and concentrated under reduced pressure to give the crude product as a yellow gum. The crude product was purified by preparative TLC on GF-254 silica using 5\% MeOH in DCM to yield a crude pale yellow gum $(250 \mathrm{mg})$. This was then purified by preparative HPLC on a kromasil C18 column using a 60:40 ratio $10 \mathrm{mM}$ ammonium bicarbonate:acetonitrile mixture. The appropriate fractions were combined, concentrated under reduced pressure and freeze dried to yield the title compound (130 mg, $62 \%) .{ }^{1} \mathrm{H}$ NMR (400 MHz, $\left.\mathrm{CDCl}_{3}\right) \delta \mathrm{ppm} 2.74(\mathrm{~d}, J=5.1 \mathrm{~Hz}, 3 \mathrm{H}), 2.94(\mathrm{~d}, J=$ $4.6 \mathrm{~Hz}, 3 \mathrm{H}), 3.66-3.74$ (m, 2 H), 4.13 (s, $3 \mathrm{H}), 4.36-4.42$ (m, 2 H), 4.93 (q, J = 5.2 Hz, 1 H), 5.97 (br. s., $1 \mathrm{H}), 6.91(\mathrm{~d}, J=8.3 \mathrm{~Hz}, 1 \mathrm{H}), 7.10(\mathrm{dd}, J=8.3,2.1 \mathrm{~Hz}, 1 \mathrm{H}), 7.18(\mathrm{~d}, J=2.1 \mathrm{~Hz}, 1 \mathrm{H}), 8.09(\mathrm{~d}, J=$ $2.7 \mathrm{~Hz}, 1 \mathrm{H}$ ), $8.31(\mathrm{~d}, J=2.7 \mathrm{~Hz}, 1 \mathrm{H})$; LCMS (Method A): $\mathrm{MH}^{+}\left(\mathrm{C}_{17} \mathrm{H}_{21} \mathrm{~N}_{4} \mathrm{O}_{5} \mathrm{~S}\right.$ ) mass required: 393 mass found: 393, Rt $0.73 \mathrm{~min}, 100 \%$ by UV.

\section{2-methoxy- $N$-methyl-5-(6-((methylamino)methyl)-2H-benzo[b][1,4]oxazin-4(3H)-yl)pyridine-3- sulfonamide, 3}

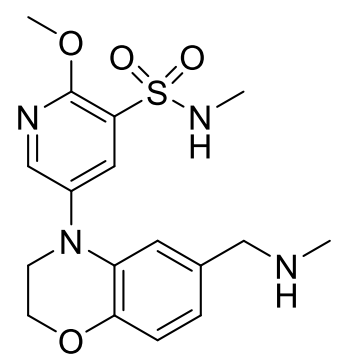

To a solution of 4-(6-methoxy-5-(N-methylsulfamoyl)pyridin-3-yl)- $N$-methyl-3,4-dihydro- $2 \mathrm{H}$ benzo[b][1,4] oxazine-6-carboxamide $(90 \mathrm{mg}, 0.23 \mathrm{mmol})$ in THF $(10 \mathrm{~mL})$ stirred under nitrogen at room temperature was added borane dimethyl sulfide complex (1M in THF, $0.69 \mathrm{~mL}, 0.69 \mathrm{mmol}$ ) dropwise. The reaction mixture was then stirred at $65{ }^{\circ} \mathrm{C}$ for $6 \mathrm{~h}$. The reaction was quenched with methanol $(5 \mathrm{~mL})$ and heated to reflux for $16 \mathrm{~h}$. The mixture was then concentrated under reduced pressure, water was added to the residue and extracted with $10 \% \mathrm{MeOH} / \mathrm{DCM}(2 \times 10 \mathrm{~mL})$. The organic 
layers were combined, dried over sodium sulfate and concentrated under reduced pressure to yield crude compound. The crude product was purified using a preparative TLC on GF-254 silica gel using 7\% $\mathrm{MeOH}$ in DCM to yield the title compound (38 mg, $42.3 \%$ yield) as pale yellow solid. ${ }^{1} \mathrm{H}$ NMR (400 MHz, DMSO- $\left.d_{6}\right) \delta$ ppm 2.39 (s, $\left.3 \mathrm{H}\right), 2.70$ (s, $\left.3 \mathrm{H}\right), 3.56$ (s, $\left.2 \mathrm{H}\right), 3.63-3.69$ (m, $\left.2 \mathrm{H}\right), 4.11(\mathrm{~s}, 3 \mathrm{H})$, 4.28-4.33 (m, $2 \mathrm{H}), 6.66(\mathrm{~d}, J=2.2 \mathrm{~Hz}, 1 \mathrm{H}), 6.74(\mathrm{dd}, J=8.2,2.2 \mathrm{~Hz}, 1 \mathrm{H}), 6.85(\mathrm{~d}, J=8.1 \mathrm{~Hz}, 1 \mathrm{H})$, $8.08(\mathrm{~d}, J=2.8 \mathrm{~Hz}, 1 \mathrm{H}), 8.26(\mathrm{~d}, J=2.8 \mathrm{~Hz}, 1 \mathrm{H})$; LCMS (Method A): $\mathrm{MH}^{+}\left(\mathrm{C}_{17} \mathrm{H}_{23} \mathrm{~N}_{4} \mathrm{O}_{4} \mathrm{~S}\right)$ mass required: 379 mass found: 379 , Rt $0.55 \mathrm{~min}, 100 \%$ by UV.

\section{9-Methoxy-15-methyl-2-oxa-11-thia-5,8,12,15-tetraazatetracyclo[15.2.2.16,(10),0(20,5)]docosa-}

\section{6,8,10(22),17,19,20-hexaen-16-one 11.11-dioxide, 13}<smiles>COc1ccc(N2CCOc3ccc(C(=O)N(C)CCNS(=O)(=O)c4ccccc4)cc32)cn1</smiles>

To a solution of 3-(benzylthio)-5-bromo-2-methoxypyridine (18.0 g, $58 \mathrm{mmol})$ in acetic acid (200 mL) and water $(67 \mathrm{~mL})$ was added $N$-chlorosuccinimide $(30.2 \mathrm{mg}, 226 \mathrm{mmol})$ and the reaction mixture was stirred at $\mathrm{rt}$ for $3 \mathrm{~h}$. The reaction was then concentrated under reduced pressure, diluted with water (500 $\mathrm{mL})$ and extracted with ethyl acetate $(3 \times 400 \mathrm{~mL})$. The combined organic layers were washed with water $(250 \mathrm{~mL})$ and brine $(250 \mathrm{~mL})$, dried over anhydrous sodium sulfate and concentrated under reduced pressure to yield sulfonyl chloride product $(15.0 \mathrm{~g})$. To a solution of tert-butyl (2aminoethyl)(methyl)carbamate $(2.8 \mathrm{~g}, 16.1 \mathrm{mmol})$, in DCM $(30 \mathrm{~mL})$ stirred under nitrogen at $0^{\circ} \mathrm{C}$ was added a solution of sulfonyl chloride product $(4.6 \mathrm{~g}, 16.1 \mathrm{mmol})$ in DCM $(30 \mathrm{~mL})$ dropwise over $1 \mathrm{~min}$. The reaction mixture was then stirred at $0{ }^{\circ} \mathrm{C}$ for $12 \mathrm{~h}$. The mixture was then washed with $10 \%$ aqueous citric acid solution $(5 \mathrm{~mL})$, saturated sodium bicarbonate solution $(5 \mathrm{~mL})$ and saturated brine $(10 \mathrm{~mL})$. The organic phase was dried over anhydrous sodium sulfate and the solvent removed under reduced pressure to yield a yellow gum. The yellow gun was purified using preparative TLC on GF-254 silica gel using $20 \%$ ethyl acetate in hexane to yield sulfonamide product $(2.3 \mathrm{~g})$. To a solution of methyl 3,4dihydro-2 $H$-benzo[b][1,4] oxazine-6-carboxylate $(301 \mathrm{mg}, 1.56 \mathrm{mmol})$, sulfonamide product (600 $\mathrm{mg}$, $1.41 \mathrm{mmol})$, and cesium carbonate $(1382 \mathrm{mg}, 4.24 \mathrm{mmol})$ in 1,4-dioxane $(3 \mathrm{~mL})$ stirred under nitrogen at $25{ }^{\circ} \mathrm{C}$, was added RuPhos $(264 \mathrm{mg}, 0.57 \mathrm{mmol})$ and $\mathrm{Pd}_{2}(\mathrm{dba})_{3}(259 \mathrm{mg}, 0.28 \mathrm{mmol})$. The reaction mixture was stirred at $100{ }^{\circ} \mathrm{C}$ for $12 \mathrm{~h}$. The mixture was washed with ethyl acetate $(50 \mathrm{~mL})$, the aqueous layer acidified with $3 \mathrm{M}$ aqueous hydrochloric acid to $\mathrm{pH} 2$ and extracted with ethyl acetate $(2 \times 50 \mathrm{~mL})$. The organic portions were combined, and concentrated under reducted pressure to yield a brown gum. This was purified by column chromatography on silica using a $50 \%$ ethyl acetate in hexane. The 
appropriate fractions were combined and evaporated in vacuo to give the coupled product $(350 \mathrm{mg})$. A solution of coupled product ( $260 \mathrm{mg}, 0.58 \mathrm{mmol}$ ), lithium hydroxide (14 mg, $0.58 \mathrm{mmol}$ ) in THF (5 $\mathrm{mL})$ and water $(2 \mathrm{~mL})$ was stirred under nitrogen at $25^{\circ} \mathrm{C}$ for $24 \mathrm{~h}$. Ethyl acetate $(15 \mathrm{~mL})$ and water $(8$ $\mathrm{mL}$ ) were added. The aqueous layer was separated and acidified to $\mathrm{pH} 2$ with $2 \mathrm{M}$ aqueous hydrochloric acid. The product was then extracted with ethyl acetate $(15 \mathrm{~mL})$ and the solvent removed under reduced pressure to yield the intermediate $(170 \mathrm{mg})$. To intermediate $(170 \mathrm{mg})$, was added $20 \%$ trifluoroacetic acid in DCM ( $3 \mathrm{~mL}, 0.33 \mathrm{mmol})$ and the mixture was stirred at $25^{\circ} \mathrm{C}$ for $1 \mathrm{~h}$. The reaction mixture was then concentrated under reduced pressure to yield a pale yellow gum $(105 \mathrm{mg})$. A solution of pale yellow gum (105 mg, $0.25 \mathrm{mmol})$, HATU (95 mg, $0.25 \mathrm{mmol})$ and triethylamine $(0.04 \mathrm{~mL}, 0.25 \mathrm{mmol})$ in DCM (3 mL) was stirred at $25{ }^{\circ} \mathrm{C}$ for $12 \mathrm{~h}$. Further DCM $(8 \mathrm{~mL})$ was added to the reaction and the mixture washed with $1 \mathrm{M}$ aqueous hydrochloric acid solution $(8 \mathrm{~mL})$ followed by saturated aqueous sodium bicarbonate solution $(8 \mathrm{~mL})$. The organic layer was separared, dried over anhydrous sodium sulphate and concentrated under reduced pressure. The crude product was purified using a preparative TLC on GF-254 silica gel using 3\% MeOH in DCM. The compound was extracted from the silica with ethanol, filtered and the solvent removed under reduced pressure to yield the title compound (21 mg, $1 \%$ yield over six steps) as an off white solid. ${ }^{1} \mathrm{H}$ NMR (400 MHz, DMSO- $\left.d_{6}\right) \delta$ ppm $2.85(\mathrm{~s}, 3 \mathrm{H})$, 3.03-3.09 (m, 2 H), 3.36 (t, $J=6.4$ Hz, 2 H), 3.71-3.76 (m, 2 H), 4.00 (s, 3 H), 4.32-4.37 (m, 2 H), 6.58 $(\mathrm{d}, J=1.7 \mathrm{~Hz}, 1 \mathrm{H}), 6.80(\mathrm{dd}, J=8.3,1.8 \mathrm{~Hz}, 1 \mathrm{H}), 6.88$ (d, $J=8.3 \mathrm{~Hz}, 1 \mathrm{H}), 7.24$ (br. s, 1H) 7.98 (d, $J=2.8 \mathrm{~Hz}, 1 \mathrm{H}), 8.31$ (d, $J=2.8 \mathrm{~Hz}, 1 \mathrm{H}) ; \mathrm{LCMS}$ (Method A): $\mathrm{MH}^{+}\left(\mathrm{C}_{18} \mathrm{H}_{21} \mathrm{~N}_{4} \mathrm{O}_{5} \mathrm{~S}\right.$ ) mass required: 405 mass found: 405, Rt $0.88 \mathrm{~min}, 100 \%$ by UV.

\section{9-Methoxy-15-methyl-2-oxa-11-thia-5,8,12,15-tetraazatetracyclo[15.2.2.16,(10),0(20,5)]docosa- 6,8,10(22),17,19,20-hexaene 11.11-dioxide, 6}<smiles>COc1ccc(N2CCOc3ccc(CN(C)CCNS(=O)(=O)c4ccccc4)cc32)cn1</smiles>

To a solution of 4-(6-methoxy-5-( $N$-(2-(methylamino)ethyl)sulfamoyl)pyridin-3-yl)-3,4-dihydro- $2 \mathrm{H}$ benzo[b][1,4] oxazine-6-carboxylic acid $(54 \mathrm{mg}, 0.13 \mathrm{mmol})$ in THF $(3 \mathrm{~mL})$ stirred under nitrogen at $65^{\circ} \mathrm{C}$ was added borane-dimethyl sulfide complex ( $1 \mathrm{M}$ in THF, $\left.0.40 \mathrm{~mL}, 0.40 \mathrm{mmol}\right)$ dropwise over 2 min. The reaction mixture was stirred at $65{ }^{\circ} \mathrm{C}$ for $3 \mathrm{hr}$. Methanol $(5 \mathrm{~mL})$ was then added and the reaction heated at reflux for $12 \mathrm{~h}$. The mixture was then concentrated under reduced pressure, the residue dissolved in ethyl acetate $(10 \mathrm{~mL})$ and washed with water $(2 \times 10 \mathrm{~mL})$. The organic layer was separated, dried over anhydrous sodium sulfate, and concentrated under reduced pressure. The residue 
was then purified by preparative HPLC on an Xbridge C18 column using a 0-50\% gradient of acetonitrile in $10 \mathrm{mM}$ ammonium bicarbonate. The appropriate fractions were combined, concentrated under reduced pressure and freeze dried to yield the title compound (3.5 $\mathrm{mg}, 7 \%)$ as an off-white solid.; ${ }^{1} \mathrm{H}$ NMR (400 MHz, DMSO- $d_{6}$ ) $\delta$ ppm 1.91 (s, $3 \mathrm{H}$ ), 2.21 (t, $\left.J=6.8 \mathrm{~Hz}, 2 \mathrm{H}\right), 2.88(\mathrm{q}, J=5.9 \mathrm{~Hz}, 2 \mathrm{H}$ ), 3.13 (s, 2 H), 3.64-3.71 (m, 2 H), 3.95 (s, 3 H), 4.20-4.26 (m, 2 H), 6.47 (d, J = 1.5 Hz, 1 H), 6.59 (dd, $J=8.2,1.6 \mathrm{~Hz}, 1 \mathrm{H}), 6.77(\mathrm{~d}, J=8.1 \mathrm{~Hz}, 1 \mathrm{H}), 7.39(\mathrm{t}, J=5.5 \mathrm{~Hz}, 1 \mathrm{H}), 7.93(\mathrm{~d}, J=2.7 \mathrm{~Hz}, 1 \mathrm{H}), 8.30$ $(\mathrm{d}, J=2.6 \mathrm{~Hz}, 1 \mathrm{H})$; LCMS (Method A): $\mathrm{MH}^{+}\left(\mathrm{C}_{18} \mathrm{H}_{23} \mathrm{~N}_{4} \mathrm{O}_{4} \mathrm{~S}\right)$ mass required: 391 mass found: 391, $\mathrm{Rt}$ $0.58 \mathrm{~min}, 99 \%$ by UV.

\section{Tert-butyl (3-(5-bromo-2-chloropyridine-3-sulfonamido)propyl)carbamate, 37}<smiles>CC(C)(C)OC(=O)NCCCNS(=O)(=O)c1cc(Br)cnc1Cl</smiles>

To a solution of 5-bromo-2-chloropyridine-3-sulfonyl chloride (2.5 g, $8.6 \mathrm{mmol})$ in 1,4-dioxane (20 $\mathrm{mL})$, was added neat pyridine $(1 \mathrm{~mL}, 12.9 \mathrm{mmol})$. The reaction mixture was stirred at room temperature for 20 mins. To the reaction mixture, was then added a solution of tert-butyl (3-aminopropyl)carbamate $(1.95 \mathrm{~g}, 11.2 \mathrm{mmol})$ in 1,4-dioxane $(15 \mathrm{~mL})$ in four aliquots over a one hour period. The reaction was then stirred at room temperature for 16 hours. The solvent was removed in vacuo and the residue dissolved in water $(30 \mathrm{~mL})$ and extracted with ethyl acetate $(30 \mathrm{~mL})$. The aqueous layer was washed with further ethyl acetate $(30 \mathrm{~mL})$ and the organic layers were combined and dried through a hydrophobic frit. The solvent was then removed in vacuo to yield the title compound $(3.22 \mathrm{~g}, 87 \%)$ as an off white solid; ${ }^{1} \mathrm{H}$ NMR (400 MHz, DMSO- $\left.d_{6}\right) \delta 1.36$ (s, 9H), 1.44-1.66 (m, 2H), 2.89 (t, $J=5.9$ Hz, 2H), 2.91 (t, $J=5.9 \mathrm{~Hz}, 2 \mathrm{H}$ ), 6.73 (br. s., 1H), 8.24 (br. s., $1 \mathrm{H}$ ), 8.44 (d, $J=2.3 \mathrm{~Hz}, 1 \mathrm{H}$ ), 8.83 (d, $J=2.3 \mathrm{~Hz}, 1 \mathrm{H}$ ); LCMS (Method A): $[\mathrm{M}-\mathrm{H}]^{-}\left(\mathrm{C}_{13} \mathrm{H}_{18} \mathrm{BrClN}_{3} \mathrm{O}_{4} \mathrm{~S}\right.$ ) mass required: 426, 428 mass found:426, 428, Rt $1.13 \mathrm{~min}, 92 \%$ by UV.

\section{Tert-butyl (3-(5-bromo-2-methoxypyridine-3-sulfonamido)propyl)carbamate, 38}

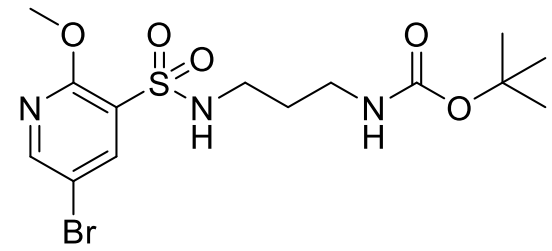

To sodium methoxide ( $3 \times 0.94 \mathrm{~g}, 17.4 \mathrm{mmol}$ ) and tert-butyl (3-(5-bromo-2-chloropyridine-3sulfonamido)propyl)carbamate ( 3 x $1.0 \mathrm{~g}, 2.3 \mathrm{mmol}$ ), was added methanol ( 3 x $16 \mathrm{~mL})$. Each reaction vial was sealed and heated under microwave irradiation to $120^{\circ} \mathrm{C}$ for 1 hour. After cooling the reaction vials were combined and quenched with water $(50 \mathrm{~mL})$. The mixture was then extracted with ethyl 
acetate $(20 \mathrm{~mL})$, however partitioning was not observed, so brine $(20 \mathrm{~mL})$ was added, and partitioning was still not observed. The mixture was then extracted with DCM $(2 \times 25 \mathrm{~mL})$ and the organic layers combined. These layers were then dried on a hydrophobic frit and the solvent removed in vacuo yielding the title compound (2.79 g, 94\%) as an off white solid. ${ }^{1} \mathrm{H}$ NMR (400 MHz, DMSO- $\left.d 6\right) \delta 1.36(\mathrm{~s}, 9 \mathrm{H})$, 1.43-1.56 (m, 2H), 2.81-2.92 (m, 4H), 4.00 (s, 3H), 6.73 (br. s., 1H), 7.69 (s, 1H), 8.16 (d, $J=2.4$ Hz, $1 \mathrm{H}), 8.55(\mathrm{~d}, J=2.4 \mathrm{~Hz}, 1 \mathrm{H})$; LCMS (Method A): [M-H] ${ }^{-}\left(\mathrm{C}_{14} \mathrm{H}_{21} \mathrm{BrN}_{3} \mathrm{O}_{5} \mathrm{~S}\right)$ mass required: 422, 424 mass found:422, 424, Rt $1.12 \mathrm{~min}, 95 \%$ by UV.

Methyl 4-(5-(N-(3-((tert-butoxycarbonyl)amino)propyl)sulfamoyl)-6-methoxypyridin-3-yl)-3,4dihydro-2H-benzo $[b][1,4]$ oxazine-6-carboxylate, 39<smiles>COC(=O)c1ccc2c(c1)N(c1cnc(OC)c(S(=O)(=O)NCCCNC(=O)OC(C)(C)C)c1)CCO2</smiles>

To tert-butyl (3-(5-bromo-2-methoxypyridine-3-sulfonamido)propyl)carbamate ( 2 x $1.25 \mathrm{~g}, 3.0 \mathrm{mmol})$, methyl 3,4-dihydro-2 $H$-benzo[b][1,4]oxazine-6-carboxylate $(2 \times 0.57 \mathrm{~g}, 3.0 \mathrm{mmol})$, dicyclohexyl(2',6'diisopropoxy-[1,1'-biphenyl]-2-yl)phosphine $\quad(2 \quad \mathrm{x} \quad 0.14 \quad \mathrm{~g}, \quad 0.30 \quad \mathrm{mmol}), \quad$ chloro(2dicyclohexylphosphino-2',6'-diisopropoxy-1,1'-biphenyl)[2-(2'-amino-1,1'-biphenyl)]palladium(II), (2 x $0.23 \mathrm{~g}, 0.30 \mathrm{mmol})$ and caesium carbonate $(2 \times 2.88 \mathrm{~g}, 8.8 \mathrm{mmol})$ was added 1,4-dioxane $(2 \mathrm{x} 14 \mathrm{~mL})$. Each reaction vial was sealed and heated under microwave irradiation to $120{ }^{\circ} \mathrm{C}$ for 2 hours. After cooling the reaction vials were combined, filtered through celite, washed with DCM (10 mL) and the solvent removed in vacuo. The residue was then dissolved in water $(20 \mathrm{~mL})$, extracted with ethyl acetate $(20 \mathrm{~mL})$ and washed with further ethyl acetate $(20 \mathrm{~mL})$. The organic layers were then combined, dried over a hydrophobic frit and the solvent removed in vacuo. The residue was then loaded, preabsorbed on florisil, and purified by column chromatography on ethyl acetate/cyclohexane gradient. The appropriate fractions were combined and concentrated in vacuo to give the title compound $(2.66 \mathrm{~g}$, $84 \%$ ) as a brown oil which solidified on standing. ${ }^{1} \mathrm{H}$ NMR (400 MHz, DMSO- $\left.d_{6}\right) \delta 1.38$ (s, 9H), 1.50 (quin, $J=6.7 \mathrm{~Hz}, 2 \mathrm{H}), 2.79-2.95(\mathrm{~m}, 4 \mathrm{H}), 3.73(\mathrm{~s}, 3 \mathrm{H}), 3.74(\mathrm{t}, J=4.4 \mathrm{~Hz}, 2 \mathrm{H}), 4.04(\mathrm{~s}, 3 \mathrm{H}), 4.39(\mathrm{t}$, $J=4.3 \mathrm{~Hz}, 2 \mathrm{H}), 6.72$ (br. s., $1 \mathrm{H}), 6.95(\mathrm{~d}, J=8.3 \mathrm{~Hz}, 1 \mathrm{H}), 7.14(\mathrm{~d}, J=2.0 \mathrm{~Hz}, 1 \mathrm{H}), 7.36(\mathrm{dd}, J=$ 8.3, $2.0 \mathrm{~Hz}, 1 \mathrm{H}$ ), 7.61 (br. s., $1 \mathrm{H}), 8.02$ (d, $J=2.8 \mathrm{~Hz}, 1 \mathrm{H}$ ), 8.41 (d, $J=2.8 \mathrm{~Hz}, 1 \mathrm{H}$ ); LCMS (Method A): $\mathrm{MH}^{+}\left(\mathrm{C}_{24} \mathrm{H}_{33} \mathrm{~N}_{4} \mathrm{O}_{8} \mathrm{~S}\right)$ mass required: 537 mass found: 537, Rt 1.20 min, $83 \%$ by UV. 
<smiles>COc1ncc(N2CCOc3ccc(C(=O)O)cc32)cc1S(=O)(=O)NCCCNC(=O)OC(C)(C)C</smiles>

To a solution of methyl 4-(5-(N-(3-((tert-butoxycarbonyl)amino)propyl)sulfamoyl)-6-methoxypyridin3-yl)-3,4-dihydro-2 $H$-benzo[b][1,4]oxazine-6-carboxylate $(2.60 \mathrm{~g}, 4.85 \mathrm{mmol})$ in THF $(12 \mathrm{~mL})$ and water $(12 \mathrm{~mL})$, stirred at room temperature, was added lithium hydroxide $(0.70 \mathrm{~g}, 29.1 \mathrm{mmol})$. The reaction mixture was stirred at room temperature for 48 hours. The reaction mixture was then acidified with $2 \mathrm{M}$ hydrochloric acid to $\mathrm{pH} 4$. The mixture was extracted with DCM (20 mL), dried over a hydrophobic frit, and the solvent removed in vacuo. This yielded the title compound (1.63 g, 64\%) as an off white solid. ${ }^{1} \mathrm{H}$ NMR (400 MHz, DMSO- $\left.d_{6}\right) \delta 1.36$ (s, 9H), 1.50 (quin, $J=6.9 \mathrm{~Hz}, 2 \mathrm{H}$ ), 2.78 $2.95(\mathrm{~m}, 4 \mathrm{H}), 3.73$ (t, $J=4.3 \mathrm{~Hz}, 2 \mathrm{H}), 4.03$ (s, 3H), 4.38 (t, $J=4.2 \mathrm{~Hz}, 2 \mathrm{H}), 6.72$ (br. s., $1 \mathrm{H}), 6.92$ $(\mathrm{d}, J=8.3 \mathrm{~Hz}, 1 \mathrm{H}), 7.14(\mathrm{~d}, J=2.0 \mathrm{~Hz}, 1 \mathrm{H}), 7.34(\mathrm{dd}, J=8.3,2.0 \mathrm{~Hz}, 1 \mathrm{H}), 7.60(\mathrm{t}, J=5.8 \mathrm{~Hz}$, $1 \mathrm{H}), 8.01(\mathrm{~d}, J=2.8 \mathrm{~Hz}, 1 \mathrm{H}), 8.40(\mathrm{~d}, J=2.5 \mathrm{~Hz}, 1 \mathrm{H}), 12.50$ (br. s., $1 \mathrm{H}$ ); LCMS (Method A): $\mathrm{MH}^{-}$ $\left(\mathrm{C}_{23} \mathrm{H}_{29} \mathrm{~N}_{4} \mathrm{O}_{8} \mathrm{~S}\right)$ mass required: 521 mass found: 521, Rt 1.06 min, $96 \%$ by UV.

9-Methoxy-2-oxa-11-thia-5,8,12,16-tetraazatetracyclo[16.2.2.16,(10),0(20,5)]tricosa1(20),6(23),7,9,18,21-hexaen-17-one 11,11-dioxide, 10<smiles>COc1ncc(N2CCOc3ccc(C(=O)NCCCNS(=O)(=O)O)cc32)cc1S(=O)(=O)O</smiles>

To a solution of 4-(5-(N-(3-((tert-butoxycarbonyl)amino)propyl)sulfamoyl)-6-methoxypyridin-3-yl)3,4-dihydro-2 $H$-benzo[b][1,4]oxazine-6-carboxylic acid (100 mg, $0.19 \mathrm{mmol})$ in DCM (2 mL), was added trifluoroacetic acid $(0.1 \mathrm{~mL}, 1.3 \mathrm{mmol})$. The reaction mixture was then stirred at room temperature for 18 hours. Further trifluoroacetic acid $(0.14 \mathrm{~mL}, 1.8 \mathrm{mmol})$ was then added and the reaction mixture stirred at room temperature for a further 5 hours. The solvent was removed in vacuo. The residue was dissolved in THF (20 mL) and HATU (90 $\mathrm{mg}, 0.24 \mathrm{mmol})$ and $\mathrm{N}, \mathrm{N}$ diisopropylethylamine $(0.061 \mathrm{~mL}, 0.47 \mathrm{mmol})$ was added. The reaction was then stirred at room temperature for 16 hours. The solvent was then removed in vacuo, the residue dissolved in water (5 
$\mathrm{mL})$, extracted with ethyl acetate $(2 \times 5 \mathrm{~mL})$. The organic layers were combined, dried over a hydrophobic frit and the solvent removed in vacuo. The sample was dissolved in DMSO and purified by mass directed HPLC using formic acid modifier. The appropriate fractions were concentrated in vacuo to give the title compound (24 mg, 25\%) as an off white solid. ${ }^{1} \mathrm{H}$ NMR (400 MHz, DMSO-d6) $\delta 1.60$ (br. s., 2H), 2.76 (br. s., 2H), 3.13 (br. s, 2H), 3.84 (t, $J=4.0 \mathrm{~Hz}, 2 \mathrm{H}$ ), 4.02 (s, 3H), 4.42 (t, $J=$ $4.0 \mathrm{~Hz}, 2 \mathrm{H}), 6.86(\mathrm{~d}, J=8.1 \mathrm{~Hz}, 1 \mathrm{H}), 7.01(\mathrm{~d}, J=7.8 \mathrm{~Hz}, 1 \mathrm{H}), 7.25$ (br. s., $1 \mathrm{H}), 7.71-7.86(\mathrm{~m}, 2 \mathrm{H})$, $8.17(\mathrm{~d}, J=2.8 \mathrm{~Hz}, 1 \mathrm{H}), 8.39(\mathrm{~d}, J=2.8 \mathrm{~Hz}, 1 \mathrm{H})$; LCMS (Method A): $\mathrm{MH}^{+}\left(\mathrm{C}_{18} \mathrm{H}_{21} \mathrm{~N}_{4} \mathrm{O}_{5} \mathrm{~S}\right.$ ) mass required: 405 mass found: 405 , Rt $0.74 \mathrm{~min}, 100 \%$ by UV.

9-Methoxy-2-oxa-11-thia-5,8,12,16-tetraazatetracyclo[16.2.2.16,(10),0(20,5)]tricosa1(20),6(23),7,9,18,21-hexaene- 11,11-dioxide, 4<smiles>COc1ccc(N2CCOc3ccc(CNCCCNS(=O)(=O)c4ccccc4)cc32)cn1</smiles>

To a solution of 9-methoxy-2-oxa-11-thia-5,8,12,16-tetraazatetracyclo [16.2.2.16,(10),0(20,5)]tricosa1(20),6(23),7,9,18,21-hexaen-17-one 11,11-dioxide (100 mg, $0.25 \mathrm{mmol})$ in 2-methyltetrahydrofuran $(1 \mathrm{~mL})$, was added $1 \mathrm{M}$ borane tetrahydrofuran complex $(0.50 \mathrm{~mL}, 0.50 \mathrm{mmol})$. The mixture was then stirred at $60{ }^{\circ} \mathrm{C}$ for 18 hours. The reaction mixture was then diluted with water $(2 \mathrm{~mL})$ and extracted with DCM ( $3 \times 2 \mathrm{~mL})$. The organic portions were combined, dried over a hydrophobic frit and the solvent was then removed in vacuo. The sample was dissolved in DMSO $(1 \mathrm{~mL})$ and purified by mass directed HPLC using an ammonium carbonate modifier. The solvent was removed in vacuo to give the title compound (17 mg, $18 \%$ ) as a white solid. ${ }^{1} \mathrm{H} \mathrm{NMR}\left(400 \mathrm{MHz}, \mathrm{CDCl}_{3}\right) \delta 1.65$ (quin, $J=6.6 \mathrm{~Hz}$, 2H), $2.58(\mathrm{t}, J=6.4 \mathrm{~Hz}, 2 \mathrm{H}), 3.24(\mathrm{t}, J=6.6 \mathrm{~Hz}, 2 \mathrm{H}), 3.74(\mathrm{~s}, 2 \mathrm{H}), 3.75-3.80(\mathrm{~m}, 2 \mathrm{H}), 4.12(\mathrm{~s}, 3 \mathrm{H})$, 4.29-4.36 (m, 2H), $6.62(\mathrm{dd}, J=8.1,1.9 \mathrm{~Hz}, 1 \mathrm{H}), 6.83(\mathrm{~d}, J=8.1 \mathrm{~Hz}, 1 \mathrm{H}), 6.97(\mathrm{~d}, J=1.8 \mathrm{~Hz}$, $1 \mathrm{H}), 8.17(\mathrm{~d}, J=2.8 \mathrm{~Hz}, 1 \mathrm{H}), 8.22(\mathrm{~d}, J=2.8 \mathrm{~Hz}, 1 \mathrm{H})$; LCMS (Method B): $\mathrm{MH}^{+}\left(\mathrm{C}_{18} \mathrm{H}_{23} \mathrm{~N}_{4} \mathrm{O}_{4} \mathrm{~S}\right)$ mass required: 391 mass found: 391 , Rt $0.87 \mathrm{~min}, 100 \%$ by UV.

Tert-butyl (4-(5-bromo-2-chloropyridine-3-sulfonamido)butyl)carbamate, 41<smiles>CC(C)(C)OC(=O)NCCCCNS(=O)(=O)c1cc(Br)cnc1Cl</smiles>

To a solution of 5-bromo-2-chloropyridine-3-sulfonyl chloride (3.0 g, $10.3 \mathrm{mmol})$ and tert-butyl (4aminobutyl)carbamate $(2.56 \mathrm{~mL}, 13.4 \mathrm{mmol})$ in 1,4-dioxane $(50 \mathrm{~mL})$, was added pyridine $(1.25 \mathrm{~mL}$, 
$15.5 \mathrm{mmol})$. The mixture was stirred at room temperature for 18 hours. The solvent was then removed in vacuo and the residue dissolved in ethyl acetate $(50 \mathrm{~mL})$. The organic layer was washed with water $(50 \mathrm{~mL})$ and the aqueous layer extracted with further ethyl acetate $(50 \mathrm{~mL})$. The organic portions were then combined, dried over a hydrophobic frit and the solvent removed in vacuo. The sample was loaded in DCM and purified by column chromatography on silica using a 0-100\% ethyl acetate:cyclohexane gradient. The appropriate fractions were combined and concentrated in vacuo to give the title compound $(2.67 \mathrm{~g}, 59 \%)$ as a colourless oil which solidified on standing. ${ }^{1} \mathrm{H}$ NMR (400 MHz, DMSO- $\left.d_{6}\right) \delta 1.31$ $1.40(\mathrm{~m}, 13 \mathrm{H}), 2.82-2.93(\mathrm{~m}, 2 \mathrm{H}), 6.73(\mathrm{t}, J=5.3 \mathrm{~Hz}, 1 \mathrm{H}), 8.27(\mathrm{~s}, 1 \mathrm{H}), 8.44(\mathrm{~d}, J=2.5 \mathrm{~Hz}, 1 \mathrm{H})$, $8.82(\mathrm{~d}, J=2.5 \mathrm{~Hz}, 1 \mathrm{H})$; LCMS (Method A): $[\mathrm{M}-\mathrm{H}]^{-}\left(\mathrm{C}_{14} \mathrm{H}_{20} \mathrm{BrClN}_{3} \mathrm{O}_{4} \mathrm{~S}\right)$ mass required: 440,442 mass found:440, 442, Rt 1.12 min, $100 \%$ by UV.

\section{Tert-butyl (4-(5-bromo-2-methoxypyridine-3-sulfonamido)butyl)carbamate, 42}<smiles>COc1ncc(Br)cc1S(=O)(=O)NCCCCNC(=O)OC(C)(C)C</smiles>

To solid sodium methoxide ( $2 \times 0.94 \mathrm{~g}, 17.4 \mathrm{mmol}$ ) and tert-butyl (4-(5-bromo-2-chloropyridine-3sulfonamido)butyl)carbamate $(2 \times 1.0 \mathrm{~g}, 2.3 \mathrm{mmol})$ was added methanol $(2 \times 16 \mathrm{~mL})$ The vials were then sealed and heated in under microwave irradiation to $120{ }^{\circ} \mathrm{C}$ for 2 hours. The reaction mixtures were combined and quenched with water $(30 \mathrm{~mL})$. The mixture was then extracted with ethyl acetate $(2 \times 30 \mathrm{~mL})$ and the organic portions combined, dried over a hydrophobic frit and the solvent removed in vacuo. The sample was loaded in DCM and purified by column chromatography on silica using a 0$100 \%$ ethyl acetate/cyclohexane gradient. The appropriate fractions were combined and concentrated in vacuo to give the title compound $(1.67 \mathrm{~g}, 84 \%)$ as a colourless oil. ${ }^{1} \mathrm{H}$ NMR (400 MHz, DMSO- $\left.d_{6}\right) \delta$ 1.30-1.35 (m, 4H), 1.37 (s, 9H), 2.81-2.88 (m, 4H), 4.00 (s, 3H), $6.72(\mathrm{t}, J=5.1 \mathrm{~Hz}, 1 \mathrm{H}), 7.72(\mathrm{~s}, 1 \mathrm{H})$, $8.16(\mathrm{~d}, J=2.5 \mathrm{~Hz}, 1 \mathrm{H}), 8.55(\mathrm{~d}, J=2.5 \mathrm{~Hz}, 1 \mathrm{H})$; LCMS (Method A): $\mathrm{MH}^{-}\left(\mathrm{C}_{15} \mathrm{H}_{23} \mathrm{BrN}_{3} \mathrm{O}_{5} \mathrm{~S}\right)$ mass required: 436, 438 mass found:436, 438, Rt 1.14 min, 100\% by UV. 
<smiles>COC(=O)c1ccc2c(c1)N(c1cnc(OC)c(S(=O)(=O)NCCCCNC(=O)OC(C)(C)C)c1)CCO2</smiles>

To solid tert-butyl (4-(5-bromo-2-methoxypyridine-3-sulfonamido)butyl)carbamate ( 2 x $0.80 \mathrm{~g}, 1.83$ mmol), methyl 3,4-dihydro- $2 H$-benzo[b][1,4]oxazine-6-carboxylate $(2 \times 0.35 \mathrm{~g}, 1.83 \mathrm{mmol})$, caesium carbonate ( 2 x $0.89 \mathrm{~g}, 2.74 \mathrm{mmol})$ and RuPhos Pd G2 ( 2 x $0.142 \mathrm{~g}, 0.183 \mathrm{mmol})$, was added 1,4-dioxane $(2 \times 12 \mathrm{~mL})$. The reaction vessels were sealed and heated in under microwave irradiation to $130{ }^{\circ} \mathrm{C}$ for 3 hours. The reaction mixtures were then combined, filtered through celite and washed with DCM (30 $\mathrm{mL}$ ). The solvent was then removed in vacuo. The sample was loaded in DCM and purified by column chromatography on silica using a $0-100 \%$ ethyl acetate/cyclohexane gradient. The appropriate fractions were combined and concentrated in vacuo to give the title compound $(1.75 \mathrm{~g}, 87 \%)$ as a yellow oil. ${ }^{1} \mathrm{H}$ NMR (400 MHz, DMSO- $\left.d_{6}\right) \delta 1.32-1.39(\mathrm{~m}, 13 \mathrm{H}), 2.78-2.94(\mathrm{~m}, 4 \mathrm{H}), 3.72(\mathrm{~s}, 3 \mathrm{H}), 3.74(\mathrm{t}, J=4.3$ $\mathrm{Hz}, 2 \mathrm{H}), 4.03(\mathrm{~s}, 3 \mathrm{H}), 4.39(\mathrm{t}, J=4.3 \mathrm{~Hz}, 2 \mathrm{H}), 6.71(\mathrm{t}, J=5.6 \mathrm{~Hz}, 1 \mathrm{H}), 6.95(\mathrm{~d}, J=8.3 \mathrm{~Hz}, 1 \mathrm{H})$, $7.13(\mathrm{~d}, J=2.0 \mathrm{~Hz}, 1 \mathrm{H}), 7.36(\mathrm{dd}, J=8.3,2.0 \mathrm{~Hz}, 1 \mathrm{H}), 7.66$ (br. s., $1 \mathrm{H}), 8.02(\mathrm{~d}, J=2.7 \mathrm{~Hz}, 1 \mathrm{H})$, $8.40(\mathrm{~d}, J=2.8 \mathrm{~Hz}, 1 \mathrm{H})$; LCMS (Method A): $\mathrm{MH}^{-}\left(\mathrm{C}_{25} \mathrm{H}_{33} \mathrm{~N}_{4} \mathrm{O}_{8} \mathrm{~S}\right)$ mass required: 549 mass found: 549, Rt 1.23 min, $92 \%$ by UV.

\section{4-(5-(N-(4-((tert-butoxycarbonyl)amino)butyl)sulfamoyl)-6-methoxypyridin-3-yl)-3,4-dihydro-}

\section{$2 H$-benzo[b][1,4]oxazine-6-carboxylic acid, 44}<smiles>COc1ncc(N2CCOc3ccc(C(=O)O)cc32)cc1S(=O)(=O)NCCCCNC(=O)OC(C)(C)C</smiles>

To a solution of methyl 4-(5-(N-(4-((tert-butoxycarbonyl)amino)butyl)sulfamoyl)-6-methoxypyridin3-yl)-3,4-dihydro-2 $H$-benzo[b][1,4]oxazine-6-carboxylate $(1.65 \mathrm{~g}, 3.0 \mathrm{mmol})$ in THF $(10 \mathrm{~mL})$ and water $(10 \mathrm{~mL})$, was added lithium hydroxide $(0.43 \mathrm{~g}, 18.0 \mathrm{mmol})$. The reaction mixture was then stirred at room temperature for 3 days. The reaction mixture was then acidified to $\mathrm{pH} 4$ using aqueous $2 \mathrm{M}$ hydrochloric acid. The mixture was extracted with DCM $(30 \mathrm{~mL})$ and dried over a hydrophobic frit. The solvent was then removed in vacuo to yield the title compound $(1.43 \mathrm{~g}, 89 \%)$ as a clear oil. ${ }^{1} \mathrm{H}$ 
NMR (400 MHz, DMSO- $\left.d_{6}\right) \delta$ 1.30-1.40 (m, 13H), 2.78-2.93 (m, 4H), $3.72(\mathrm{t}, J=4.3 \mathrm{~Hz}, 2 \mathrm{H}), 4.02$ (s, 3H), 4.32-4.40 (m, 2H), $6.75(\mathrm{t}, J=5.3 \mathrm{~Hz}, 1 \mathrm{H}), 6.87(\mathrm{~d}, J=8.3 \mathrm{~Hz}, 1 \mathrm{H}), 7.14(\mathrm{~d}, J=2.0 \mathrm{~Hz}$, $1 \mathrm{H}), 7.32(\mathrm{dd}, J=8.3,2.0 \mathrm{~Hz}, 1 \mathrm{H}), 7.63(\mathrm{t}, J=5.8 \mathrm{~Hz}, 1 \mathrm{H}), 8.00(\mathrm{~d}, J=2.8 \mathrm{~Hz}, 1 \mathrm{H}), 8.38(\mathrm{~d}, J=$ $2.8 \mathrm{~Hz}, 1 \mathrm{H}$ ); LCMS (Method A): $\mathrm{MH}^{-}\left(\mathrm{C}_{24} \mathrm{H}_{31} \mathrm{~N}_{4} \mathrm{O}_{8} \mathrm{~S}\right)$ mass required: 535 mass found: 535, Rt 1.08 min, $92 \%$ by UV.

\section{9-Methoxy-2-oxa-11-thia-5,8,12,17-tetraazatetracyclo[17.2.2.16,10,0(20,5)]tetracosa-} 1(21),6(24),7,9,19,22-hexaen-18-one 11,11-dioxide, 11<smiles>COc1ccc(N2CCOc3ccc(C(=O)NCCCCNS(=O)(=O)c4cccc(N)c4)cc32)cn1</smiles>

To a solution of 4-(5-(N-(4-((tert-butoxycarbonyl)amino)butyl)sulfamoyl)-6-methoxypyridin-3-yl)3,4-dihydro-2 $H$-benzo[b][1,4]oxazine-6-carboxylic acid $(1.0 \mathrm{~g}, 1.9 \mathrm{mmol})$ in DCM (20 mL), was added trifluoroacetic acid $(2.30 \mathrm{~mL}, 29.8 \mathrm{mmol})$ and the reaction mixture was stirred at room temperature for 18 hours. The solvent was then removed in vacuo. The residue was then dissolved in $N, N$ dimethylformamide $(50 \mathrm{~mL})$ to this was added HATU $(700 \mathrm{mg}, 1.8 \mathrm{mmol})$ and DIPEA $(0.64 \mathrm{~mL}, 3.7$ mmol) The reaction mixture was then stirred at room temperature for 48 hours. The reaction mixture was then diluted with saturated aqueous sodium hydrogen carbonate $(50 \mathrm{~mL})$ and extracted with ethyl acetate $(3 \times 30 \mathrm{~mL})$. The organic portions were then combined, dried over a hydrophobic frit and the solvent removed in vacuo to yield crude product $(680 \mathrm{mg})$. Two samples $(2 \times 90 \mathrm{mg})$ were dissolved in DMSO (2 x $1 \mathrm{~mL})$ and purified by mass directed HPLC on Xbridge column using acetonitrile/water with an ammonium carbonate modifier. The solvent was removed in vacuo to give the title compound (13 $\mathrm{mg}, 2 \%)$ as an off white solid. The remaining crude product was loaded in DMSO and purified by column chromatography on $\mathrm{C}_{18}$ reverse phase using a 0-100 water:acetonitrile gradient. The appropriate fractions from reverse phase purification were combined and concentrated in vacuo to give the title compound (200 mg, 26\%) as an off-white solid. ${ }^{1} \mathrm{H}$ NMR (400 MHz, DMSO- $\left.d_{6}\right) \delta 1.33-1.47$ (m, 4H), 2.87 (br. s., $2 \mathrm{H}$ ), 3.06-3.15 (m, 2H), 3.80 (t, $J=4.3 \mathrm{~Hz}, 2 \mathrm{H}), 4.03(\mathrm{~s}, 3 \mathrm{H}), 4.42(\mathrm{t}, J=4.3 \mathrm{~Hz}, 2 \mathrm{H})$, $6.85(\mathrm{~d}, J=8.2 \mathrm{~Hz}, 1 \mathrm{H}), 7.03(\mathrm{~d}, J=1.9 \mathrm{~Hz}, 1 \mathrm{H}), 7.07(\mathrm{dd}, J=8.2,1.9 \mathrm{~Hz}, 1 \mathrm{H}), 7.69$ (br. s., $1 \mathrm{H})$, $7.95(\mathrm{t}, J=5.6 \mathrm{~Hz}, 1 \mathrm{H}), 8.04(\mathrm{~d}, J=2.8 \mathrm{~Hz}, 1 \mathrm{H}), 8.38(\mathrm{~d}, J=2.7 \mathrm{~Hz}, 1 \mathrm{H})$; LCMS (Method A): $\mathrm{MH}^{+}\left(\mathrm{C}_{19} \mathrm{H}_{23} \mathrm{~N}_{4} \mathrm{O}_{5} \mathrm{~S}\right)$ mass required: 418 mass found: 418 , Rt 0.80 min, $87 \%$ by UV. 


\section{9-Methoxy-2-oxa-11-thia-5,8,12,17-tetraazatetracyclo[17.2.2.16,10,0(20,5)]tetracosa-}

\section{1(21),6(24),7,9,19,22-hexaen-18-one 11,11-dioxide, 5}<smiles></smiles>

To a solution of 9-methoxy-2-oxa-11-thia-5,8,12,17-tetraazatetracyclo [17.2.2.16,10,0(20,5)]tetracosa1(21),6(24),7,9,19,22-hexaen-18-one 11,11-dioxide (40 mg, $0.09 \mathrm{mmol}$ ) in THF (1.5 mL), stirred at 0 ${ }^{\circ} \mathrm{C}$, was added diisobutylaluminum hydride (1 M in THF, $0.35 \mathrm{~mL}, 0.35 \mathrm{mmol}$ ) The reaction mixture was then allowed to warm to room temperature and was stirred for a further 18 hours. The reaction was cooled to $0{ }^{\circ} \mathrm{C}$ and quenched with water $(1.5 \mathrm{~mL})$. The reaction mixture was then extracted with ethyl acetate $(3 \times 5 \mathrm{~mL})$, the organic portions combined, dried over a hydrophobic frit and the solvent removed in vacuo. The sample was dissolved in DMSO $(1 \mathrm{~mL})$ and purified by mass directed HPLC on Xbridge column using acetonitrile/water with an ammonium carbonate modifier.The solvent was removed in vacuo to give the title compound $(6 \mathrm{mg}, 16 \%) .{ }^{1} \mathrm{H} \mathrm{NMR}\left(400 \mathrm{MHz}, \mathrm{CDCl}_{3}\right) \delta 1.32-1.41(\mathrm{~m}$, $2 \mathrm{H}), 1.46-1.55(\mathrm{~m}, 2 \mathrm{H}), 2.54(\mathrm{t}, J=5.8 \mathrm{~Hz}, 2 \mathrm{H}), 3.09-3.19(\mathrm{~m}, 2 \mathrm{H}), 3.61(\mathrm{~s}, 2 \mathrm{H}), 3.71(\mathrm{t}, J=4.3 \mathrm{~Hz}$, 2H), 4.16 (s, 3H), 4.43 (t, $J=4.5 \mathrm{~Hz}, 2 \mathrm{H}), 4.99$ (br. s., $1 \mathrm{H}), 6.54$ (dd, $J=7.8,1.8 \mathrm{~Hz}, 1 \mathrm{H}), 6.57$ (d, $J=1.8 \mathrm{~Hz}, 1 \mathrm{H}), 6.78(\mathrm{~d}, J=7.8 \mathrm{~Hz}, 1 \mathrm{H}), 8.10-8.29(\mathrm{~m}, 2 \mathrm{H}) ; \mathrm{LCMS}\left(\right.$ Method A): $\mathrm{MH}^{-}\left(\mathrm{C}_{19} \mathrm{H}_{23} \mathrm{~N}_{4} \mathrm{O}_{4} \mathrm{~S}\right)$ mass required: 405 mass found: 405, Rt 0.99 min, $99 \%$ by UV.

tert-butyl (3-(5-bromo-2-methoxypyridine-3-sulfonamido)propyl)(methyl)carbamate, 45<smiles>COc1ncc(Br)cc1S(=O)(=O)NCCCN(C)C(=O)OC(C)(C)C</smiles>

To a solution of 3-(benzylthio)-5-bromo-2-methoxypyridine (18.0 g, $58 \mathrm{mmol})$ in acetic acid $(200 \mathrm{~mL})$ and water $(67 \mathrm{~mL})$ was added $N$-chlorosuccinimide $(30.2 \mathrm{~g}, 226 \mathrm{mmol})$ and the reaction mixture was stirred at $\mathrm{rt}$ for $3 \mathrm{~h}$. The reaction was then concentrated under reduced pressure, diluted with water (500 $\mathrm{mL})$ and extracted with ethyl acetate $(3 \times 400 \mathrm{~mL})$. The combined organic layers were washed with water $(250 \mathrm{~mL})$ and brine $(250 \mathrm{~mL})$, dried over anhydrous sodium sulfate and concentrated under reduced pressure to yield sulfonyl chloride product $(15.0 \mathrm{~g})$. To a solution of sulfonyl chloride $(4 \mathrm{~g}$, $13.96 \mathrm{mmol})$, and tert-butyl (3-aminopropyl)(methyl)carbamate (3.94 g, $20.9 \mathrm{mmol})$ in DCM (50 mL), was added pyridine $(50 \mathrm{~mL})$. The reaction was then stirred under nitrogen at room temp for $12 \mathrm{~h}$. The 
mixture was concentrated under reduced puressure, to give crude product. This was then purified by column chromatography on silica using $25 \%$ ethyl acetate in hexane to give the title compound $(4.1 \mathrm{~g}$, $68 \%$ yield) as pale yellow gum. ${ }^{1} \mathrm{H}$ NMR $\left(400 \mathrm{MHz}, \mathrm{CDCl}_{3}\right) \delta$ ppm $1.44(\mathrm{~s}, 9 \mathrm{H}), 1.62$ (br. s., $2 \mathrm{H}$ ), 2.79 (s, $3 \mathrm{H}), 2.98$ (q, $J=6.4 \mathrm{~Hz}, 2 \mathrm{H}), 3.27$ (t, $J=6.1 \mathrm{~Hz}, 2 \mathrm{H}), 4.09$ (s, $3 \mathrm{H}), 6.31$ (br. s, $1 \mathrm{H}), 8.25$ (br. s, $1 \mathrm{H}$ ), 8.34 (br. s., $1 \mathrm{H}$ ); LCMS (Method C): [M-H] $]^{-}\left(\mathrm{C}_{15} \mathrm{H}_{23}{ }^{79} \mathrm{BrN}_{3} \mathrm{O}_{5} \mathrm{~S}\right.$ ) mass required: 436 mass found: 436, Rt $3.71 \mathrm{~min}, 97 \%$ by UV.

\section{4-(6-methoxy-5-(N-(3-(methylamino)propyl)sulfamoyl)pyridin-3-yl)-3,4-dihydro-2H- benzo $[b][1,4]$ oxazine-6-carboxylic acid, 46}<smiles>COc1ncc(N2CCOc3ccc(C(=O)O)cc32)cc1S(=O)(=O)NCCCN(C)C(=O)OC(C)(C)C</smiles>

To a degassed solution of tert-butyl (3-(5-bromo-2-methoxypyridine-3sulfonamido)propyl)(methyl)carbamate $(1.00 \mathrm{~g}, \quad 2.28 \mathrm{mmol})$, methyl 3,4-dihydro- $\mathrm{H}$ benzo[b][1,4]oxazine-6-carboxylate $(0.49 \mathrm{~g}, 2.51 \mathrm{mmol})$, dicyclohexyl(2',6'-diisopropoxy-[1,1'biphenyl]-2-yl)phosphine $(0.43 \mathrm{~g}, 0.91 \mathrm{mmol})$ and cesium carbonate $(2.23 \mathrm{~g}, 6.84 \mathrm{mmol})$ in 1,4-dioxane $(20 \mathrm{~mL})$ stirred under argon, was added $\mathrm{Pd}_{2}(\mathrm{dba})_{3}(0.42 \mathrm{~g}, 0.46 \mathrm{mmol})$. The reaction mixture was stirred at $105^{\circ} \mathrm{C}$ for $72 \mathrm{~h}$. The mixture was filtered through celite, the filtrate was diluted with water $(20 \mathrm{~mL})$ and extracted with ethyl acetate $(3 \times 20 \mathrm{~mL})$. The combined organic portions were dried over anhydrous sodium sulfate and concentrated under reduced pressure to give the crude product. This was purified on by column chromatography on silica using $20 \%$ ethyl acetate in hexane to give coupled product ( 800 $\mathrm{mg}, 0.944 \mathrm{mmol}, 41.4 \%$ yield $)$ as pale yellow solid. To a solution of methyl 4-(5-( $N$-(3-((tertbutoxycarbonyl)(methyl)amino)propyl)sulfamoyl)-6-methoxypyridin-3-yl)-3,4-dihydro-2 $H$ benzo[b][1,4] oxazine-6-carboxylate $(470 \mathrm{mg}, 0.85 \mathrm{mmol})$, in THF $(7.5 \mathrm{~mL})$ and water $(7.5 \mathrm{~mL})$, was added lithium hydroxide $(123 \mathrm{mg}, 5.12 \mathrm{mmol})$. The reaction mixture was stirred at room temperature for $72 \mathrm{~h}$. Ethyl acetate $(7.5 \mathrm{~mL})$ and water $(7.5 \mathrm{~mL})$ were added and the aqueous layer separated. The aqueous layer was then washed with ethyl acetate $(2 \times 20 \mathrm{~mL})$, acidified with $1 \mathrm{M}$ aqueous hydrochloric acid and the product extracted with ethyl acetate $(3 \times 20 \mathrm{~mL})$. The combined organic portions were dried over anhydrous sodium sulfate and concentrated under reduced pressure to yield the title compound (300 mg, 56\%) as a red gum. ${ }^{1} \mathrm{H}$ NMR (400 MHz, $\left.\mathrm{CDCl}_{3}\right) \delta$ ppm 1.34 (s, $\left.9 \mathrm{H}\right), 1.58$ (br. s., 2 H), 2.67-2.71 (m, 2 H), 2.80-2.89 (m, 2 H), 3.07-3.16 (m, 2 H), 3.72 (s, 3 H), 4.03 (s, 3 H), 4.33-4.42 $(\mathrm{m}, 2 \mathrm{H}), 6.94(\mathrm{~d}, J=8.3 \mathrm{~Hz}, 1 \mathrm{H}), 7.13(\mathrm{~d}, J=2.01 \mathrm{H}), 7.36(\mathrm{dd}, J=8.3,2.0 \mathrm{~Hz}, 1 \mathrm{H}), 8.02(\mathrm{~d}, J=2.6$ 
$\mathrm{Hz}, 1 \mathrm{H}), 8.41(\mathrm{~d}, J=2.6 \mathrm{~Hz}, 1 \mathrm{H})$; LCMS (Method C): $(\mathrm{M}-\mathrm{H})^{-}\left(\mathrm{C}_{24} \mathrm{H}_{31} \mathrm{~N}_{4} \mathrm{O}_{8} \mathrm{~S}\right)$ mass required: 535 mass found: 535, Rt $2.30 \mathrm{~min}, 85 \%$ by UV.

9-Methoxy-16-methyl-2-oxa-11-thia-5,8,12,16-tetraazatetracyclo[16.2.2.16,(10),0(20,5)]tricosa1(20),6(23),7,9,18,21-hexaen-17-one 11,11-dioxide, 14<smiles>CNCCCN(C)C(=O)c1ccc2c(c1)N(c1cnc(OC)c(S(=O)(=O)NC)c1)CCO2</smiles>

To a solution of methyl 4-(5-(N-(3-((tert-butoxycarbonyl)(methyl)amino)propyl)sulfamoyl)-6methoxypyridin-3-yl)-3,4-dihydro-2 $H$-benzo[b][1,4]oxazine-6-carboxylate (300 mg, $0.55 \mathrm{mmol}$ ), in DCM $(5 \mathrm{~mL})$ stirred under nitrogen at room temp was added $20 \%$ trifluoroacetic acid in DCM (5 mL, $13.0 \mathrm{mmol})$. The reaction was then stirred at room temperature for $4 \mathrm{~h}$. The solvent was then removed under reduced pressure to yield a brown gum $(290 \mathrm{mg})$. To a solution of brown gum $(290 \mathrm{mg}, 0.66$ $\mathrm{mmol})$, in DCM $(10 \mathrm{~mL})$ stirred under nitrogen at room temperature, was added triethylamine $(0.37$ $\mathrm{mL}, 2.7 \mathrm{mmol})$, followed by HATU $(505 \mathrm{mg}, 1.33 \mathrm{mmol})$. The reaction was then stirred for $24 \mathrm{~h}$. The mixture was diluted with $\mathrm{DCM}(10 \mathrm{~mL})$ and washed with $1 \mathrm{M}$ aqueous $\mathrm{HCl}(10 \mathrm{~mL})$, followed by saturated sodium bicarbonate solution $(10 \mathrm{~mL})$ and water $(10 \mathrm{~mL})$. The organic portion was dried over anhydrous sodium sulfate and concentrated under reduced pressure to give crude product. This was then purified by preparative TLC using $2 \%$ methanol in DCM to yield an off white solid. The white solid was co-distilled with water under reduced pressure to afford a white solid and this was freeze dried to yield the title compound (22 mg, $8 \%$ yield) as white solid. ${ }^{1} \mathrm{H}$ NMR (400 MHz, DMSO- $\left.d_{6}\right) \delta$ ppm 1.41 (br. s., 2 H), 2.79 (s, 3 H), 3.03-3.17 (m, 4 H), 3.72-3.77 (m, 2 H), 3.98 (s, 3 H), 4.30 (t, J = 3.9 Hz, 2 H), 6.41 (br. s., 1 H), 6.82 (dd, $J=8.3,2.0 \mathrm{~Hz}, 1 \mathrm{H}$ ), 6.92 (d, $J=8.3 \mathrm{~Hz}, 1 \mathrm{H}$ ), 7.97 (br. s., $1 \mathrm{H}$ ), 8.18 $(\mathrm{d}, J=2.6 \mathrm{~Hz}, 1 \mathrm{H}), 8.35(\mathrm{~d}, J=2.6 \mathrm{~Hz}, 1 \mathrm{H})$; LCMS (Method A): $\mathrm{MH}^{+}\left(\mathrm{C}_{19} \mathrm{H}_{23} \mathrm{~N}_{4} \mathrm{O}_{5} \mathrm{~S}\right.$ ) mass required: 419 mass found: 419 , Rt $0.72 \mathrm{~min}, 99 \%$ by UV.

9-Methoxy-16-methyl-2-oxa-11-thia-5,8,12,16-tetraazatetracyclo[16.2.2.16,(10),0(20,5)]tricosa1(20),6(23),7,9,18,21-hexaene- 11,11-dioxide, 7<smiles>COc1ncc(N2CCOc3ccc(CN4CCCN(C)CC4)cc32)cc1S(=O)(=O)O</smiles> 
To

a solution

of

9-methoxy-16-methyl-2-oxa-11-thia-5,8,12,16-

tetraazatetracyclo[16.2.2.16,(10),0(20,5)]tricosa-1(20),6(23),7,9,18,21-hexaen-17-one 11,11-dioxide $(65 \mathrm{mg}, 0.10 \mathrm{mmol})$ in THF $(5 \mathrm{~mL})$ stirred under nitrogen at room temperature, was added borane dimethylsulfide complex ( $1 \mathrm{M}$ in THF, $0.30 \mathrm{~mL}, 0.30 \mathrm{mmol}$ ). The reaction mixture was then stirred at $65^{\circ} \mathrm{C}$ for $6 \mathrm{~h}$. The reaction was then cooled to room temperature, excess methanol was added and the mixture heated at $65{ }^{\circ} \mathrm{C}$ for $12 \mathrm{~h}$. The mixture was then concentrated under reduced pressure, and purified by preparative TLC on GF 254 silica coated glass plates using $2 \%$ methanol in DCM. The product was then freeze dried to yield the title compound (12 mg, 27\%) as an off-white solid. ${ }^{1} \mathrm{H}$ NMR $\left(600 \mathrm{MHz}, \mathrm{DMSO}-d_{6}\right) \delta$ ppm 1.40-1.53 (m, 2H), 2.16 (br. s, 3H), 2.22 (br. s, 2H), 2.90-3.01 (m, 2H), 3.32-3.37 (m, 2H), 3.76 (br. s, 2H), 3.96 (s, 3H), 4.21 (br. s, 2H), 6.59 (br. d, $J=7.5 \mathrm{~Hz}$, 1H), 6.77 (br. d, $J=7.9 \mathrm{~Hz}, 1 \mathrm{H}$ ), 6.90 (br. s, 1H), 7.69 (br. s, 1H), 8.02 (br s, 1H), 8.31 (br. s, $1 \mathrm{H})$; LCMS (Method A): $\mathrm{MH}^{+}\left(\mathrm{C}_{19} \mathrm{H}_{25} \mathrm{~N}_{4} \mathrm{O}_{4} \mathrm{~S}\right)$ mass required: 405 mass found: 405, Rt $0.55 \mathrm{~min}, 98 \%$ by UV.

\section{$N$-allyl-5-bromo-2-methoxypyridine-3-sulfonamide, 47}<smiles>C=CCNS(=O)(=O)c1cc(Br)cnc1OC</smiles>

To a solution of 3-(benzylthio)-5-bromo-2-methoxypyridine $(23.0 \mathrm{~g}, 74 \mathrm{mmol})$ in acetic acid $(230 \mathrm{~mL})$ and water $(67 \mathrm{~mL})$ was added $N$-chlorosuccinimide $(38.6 \mathrm{~g}, 226 \mathrm{mmol})$ and the reaction mixture was stirred at room temperature for $3 \mathrm{~h}$. The reaction was then concentrated under reduced pressure, diluted with water $(500 \mathrm{~mL})$ and extracted with ethyl acetate $(3 \times 400 \mathrm{~mL})$. The combined organic layers were washed with water $(250 \mathrm{~mL})$ and brine $(250 \mathrm{~mL})$, dried over anhydrous sodium sulfate and concentrated under reduced pressure to yield sulfonyl chloride product ( $20.0 \mathrm{~g}$ ) as a yellow liquid. To a solution of yellow liquid $(18.0 \mathrm{~g}, 63 \mathrm{mmol})$ and allylamine $(5.7 \mathrm{~mL}, 75 \mathrm{mmol})$ in DCM $(100 \mathrm{~mL})$ stirred under nitrogen, was added pyridine $(100 \mathrm{~mL})$. The reaction mixture was then stirred at room temperature for $16 \mathrm{~h}$. The mixture was diluted with water $(200 \mathrm{~mL})$ and extracted with DCM (3 x $200 \mathrm{~mL})$. The combined organic layers were washed with water $(500 \mathrm{~mL}), 1 \mathrm{M}$ hydrochloric acid $(400 \mathrm{~mL})$ and saturated brine $(200 \mathrm{~mL})$, dried over sodium sulphate and concentrated under reduced pressure to yield a brown liquid. This was triturated with $n$-pentane $(3 \times 50 \mathrm{~mL})$, decanted and dried under high vacuum to yield the title compound $(10.0 \mathrm{~g}, 44 \%)$ as a brown solid. ${ }^{1} \mathrm{H} \mathrm{NMR}\left(400 \mathrm{MHz}, \mathrm{CDCl}_{3}\right) \delta \mathrm{ppm} 3.61$ (tt, $J=6.1,1.3 \mathrm{~Hz}, 2 \mathrm{H}), 4.09$ (s, $3 \mathrm{H}), 4.98(\mathrm{t}, J=5.7 \mathrm{~Hz}, 1 \mathrm{H}), 5.12(\mathrm{dd}, J=10.5,1.1 \mathrm{~Hz}, 1 \mathrm{H}), 5.18$ (dd, $J=16.8,1.1 \mathrm{~Hz}, 1 \mathrm{H}), 5.70(\mathrm{ddt}, J=16.8,10.5,5.9,5.9 \mathrm{~Hz}, 1 \mathrm{H}), 8.27(\mathrm{~d}, J=2.4 \mathrm{~Hz}, 1 \mathrm{H}), 8.38(\mathrm{~d}, J$ $=2.4 \mathrm{~Hz}, 1 \mathrm{H}$ ); LCMS (Method D): $\mathrm{MH}^{+}\left(\mathrm{C}_{9} \mathrm{H}_{12} \mathrm{BrN}_{2} \mathrm{O}_{3} \mathrm{~S}\right.$ ) mass required: 307, 309 mass found: 307, 309 , Rt 2.55 min, $94 \%$ by UV. 


\section{4-(5-( $N$-allylsulfamoyl)-6-methoxypyridin-3-yl)-3,4-dihydro-2H-benzo[b][1,4]oxazine-6- carboxylic acid, 48}<smiles>C=CCNS(=O)(=O)c1cc(N2CCOc3ccc(C(=O)O)cc32)cnc1OC</smiles>

To a solution of methyl 3,4-dihydro-2 $H$-benzo[b][1,4]oxazine-6-carboxylate $(3.14 \mathrm{~g}, 16.3 \mathrm{mmol}), \mathrm{N}$ allyl-5-bromo-2-methoxypyridine-3-sulfonamide $(5.00 \mathrm{~g}, 16.3 \mathrm{mmol})$ and cesium carbonate $(15.9 \mathrm{~g}$, $48.8 \mathrm{mmol})$ in 1,4-dioxane $(100 \mathrm{~mL})$ stirred under nitrogen at room temperature and degassed for 20 min, was added $\mathrm{Pd}_{2}(\mathrm{dba})_{3}(2.98 \mathrm{~g}, 3.3 \mathrm{mmol})$ followed by RuPhos $(3.03 \mathrm{~g}, 6.5 \mathrm{mmol})$. The reaction mixture was stirred at $105^{\circ} \mathrm{C}$ for $16 \mathrm{~h}$. The reaction mixture was filtered through celite, washed with ethyl acetate $(50 \mathrm{~mL})$ and the filterate concentrated under reduced pressure to yield a crude brown gum $(4.0 \mathrm{~g})$. The crude product was purified column chromatography on silica using $20 \%$ ethyl acetate in hexane. The appropriate fractions were combined, and concentrated under reduced pressure to yield the coupled product $(1.70 \mathrm{~g})$ as a pale yellow gum. To a solution of pale yellow gum $(1.7 \mathrm{~g}, 4.1 \mathrm{mmol})$ in THF $(20 \mathrm{~mL})$ at $0{ }^{\circ} \mathrm{C}$, was added a solution of lithium hydroxide monohydrate $(0.680 \mathrm{~g}, 16.2 \mathrm{mmol})$ in water $(5 \mathrm{~mL})$. The reaction mixture was stirred at room temperature for $24 \mathrm{~h}$. The mixture was then concentrated under reduced pressure, diluted with water $(10 \mathrm{~mL})$ and washed with diethyl ether $(3 \mathrm{x} 20$ $\mathrm{mL}$ ). The aqueous portion was acidified to $\mathrm{pH} 4$ with $1 \mathrm{M}$ aqueous hydrochloric acid, the precipitate collected by filtration and dried in vacuo to yield the title compound (750 mg, 7\%) as an off-white solid. ${ }^{1} \mathrm{H}$ NMR (400 MHz, DMSO- $\left.d_{6}\right) \delta$ ppm $3.55(\mathrm{t}, J=5.7 \mathrm{~Hz}, 2 \mathrm{H}), 3.64-3.76(\mathrm{~m}, 2 \mathrm{H}), 4.02$ (s, $\left.3 \mathrm{H}\right), 4.30-$ $4.42(\mathrm{~m}, 2 \mathrm{H}), 4.97$ (dd, $J=10.3,1.4 \mathrm{~Hz}, 1 \mathrm{H}), 5.08$ (dd, $J=17.3,1.4 \mathrm{~Hz}, 1 \mathrm{H}), 5.64$ (ddt, $J=17.3$, 10.3, 5.7, $5.7 \mathrm{~Hz}, 1 \mathrm{H}), 6.91(\mathrm{~d}, J=8.3 \mathrm{~Hz}, 1 \mathrm{H}), 7.10(\mathrm{~d}, J=2.0 \mathrm{~Hz}, 1 \mathrm{H}), 7.33(\mathrm{dd}, J=8.3,2.0 \mathrm{~Hz}, 1$ H), $7.88(\mathrm{t}, J=5.5 \mathrm{~Hz}, 1 \mathrm{H}), 8.00(\mathrm{~d}, J=2.6 \mathrm{~Hz}, 1 \mathrm{H}), 8.39$ (d, $J=2.6 \mathrm{~Hz}, 1 \mathrm{H}), 12.49$ (br. s., $1 \mathrm{H})$; LCMS (Method C): $\mathrm{MH}^{+}\left(\mathrm{C}_{18} \mathrm{H}_{20} \mathrm{~N}_{3} \mathrm{O}_{6} \mathrm{~S}\right)$ mass required: 406 mass found: 406, Rt $2.62 \mathrm{~min}, 86 \%$ by UV. 
<smiles>COc1ccc(N2CCOc3ccc(C(=O)N(C)CCCCNS(=O)(=O)c4cccc(N)c4)cc32)cn1</smiles>

To a solution of 4-(5-( $N$-allylsulfamoyl)-6-methoxypyridin-3-yl)-3,4-dihydro- $2 \mathrm{H}$ benzo[ $b][1,4]$ oxazine-6-carboxylic acid $\quad(750 \quad \mathrm{mg}, \quad 1.9 \quad \mathrm{mmol}), \quad$ 1-ethyl-3-(3dimethylaminopropyl)carbodiimide (530 mg, $2.8 \mathrm{mmol}$ ) and 1-hydroxybenzotriazole $(425 \mathrm{mg}, 2.8$ mmol) in DCM $(30 \mathrm{~mL})$ stirred under nitrogen at $0^{\circ} \mathrm{C}$, was added di-iso-propylethyl amine $(0.97 \mathrm{~mL}$, $5.6 \mathrm{mmol})$ and the mixture was stirred for $15 \mathrm{~min}$. $N$-methylprop-2-en-1-amine $(0.27 \mathrm{~mL}, 2.8 \mathrm{mmol})$ dropwise. The reaction was then stirred at room temperature for $16 \mathrm{~h}$. The mixture was diluted with water $(50 \mathrm{~mL})$ and extracted with DCM $(3 \mathrm{x} 40 \mathrm{~mL})$. The combined organic portions were washed with water $(50 \mathrm{~mL})$ and saturated brine $(50 \mathrm{~mL})$, dried over sodium sulfate and concentrated under reduced proessure to yield a pale brown gum $(850 \mathrm{mg})$. To a solution of pale brown gum $(750 \mathrm{mg}, 1.6 \mathrm{mmol})$ in DCM $(150 \mathrm{~mL})$ stirred and degassed for $30 \mathrm{~min}$ at room temperature, was added Grubbs $2^{\text {nd }}$ Generation Catalyst $(278 \mathrm{mg}, 0.33 \mathrm{mmol})$. The reaction mixture was stirred at $40{ }^{\circ} \mathrm{C}$ for $24 \mathrm{~h}$. The mixture was then filtered through celite and washed with DCM $(100 \mathrm{~mL})$. The filtrate was concentrated under reduced pressure to yield a black solid $(800 \mathrm{mg})$. This was purified by column chromatography on silica using $60 \%$ ethyl acetate in hexane. The appropriate fractions were combined and concentrated under reduced pressure to yield a pale brown solid $(450 \mathrm{mg})$. To a solution of pale brown solid (450 $\mathrm{mg}, 1.0 \mathrm{mmol})$ in methanol $(15 \mathrm{~mL})$, was added palladium on carbon $(111 \mathrm{mg}, 0.1 \mathrm{mmol})$. The reaction mixture was then stirred under an atmosphere of hydrogen at room temperature for $12 \mathrm{~h}$. The reaction mixture was then filtered through celite, washed with methanol $(30 \mathrm{~mL})$ and concentrated under reduced pressure to yield a pale brown solid (400 mg). This was then purified by preparative HPLC on a YMCPack reverse phase column using a 20-90\% acetonitrile in $10 \mathrm{mM}$ ammonium bicarbonate gradient. The appropriate fraction were combined and concentrated under reduced pressure to yield the title compound (280 mg, 28\%) as a pale yellow solid. ${ }^{1} \mathrm{H}$ NMR (400 MHz, DMSO- $\left.d_{6}\right) \delta$ ppm 1.12-1.25 (m, 2 H), 1.27-1.37 (m, 2 H), 2.77 (s, 3 H), 3.02 (br. s., 2 H), 3.15 (br. s., 2 H), 3.70-3.78 (m, 2 H), 4.02 (s, $3 \mathrm{H}), 4.36-4.43$ (m, $2 \mathrm{H}), 6.06$ (br. s., $1 \mathrm{H}), 6.66$ (dd, $J=8.1,1.5 \mathrm{~Hz}, 1 \mathrm{H}), 6.85$ (d, $J=8.1 \mathrm{~Hz}, 1 \mathrm{H})$, 7.77 (br. s., $1 \mathrm{H}$ ), 8.04 (d, $J=2.6 \mathrm{~Hz}, 1 \mathrm{H}$ ), 8.36 (d, $J=2.7 \mathrm{~Hz}, 1 \mathrm{H}$ ); LCMS (Method A): $\mathrm{MH}^{+}$ $\left(\mathrm{C}_{20} \mathrm{H}_{25} \mathrm{~N}_{4} \mathrm{O}_{5} \mathrm{~S}\right)$ mass required: 433 mass found: 433 , Rt 0.77 min, $100 \%$ by UV. 
<smiles>COc1ccc(N2CCOc3ccc(CN(C)CCCCNS(=O)(=O)c4ccccc4)cc32)cn1</smiles>

To

a solution

of

9-Methoxy-17-methyl-2-oxa-11-thia-5,8,12,17tetraazatetracyclo[17.2.2.16,10,0(20,5)]tetracosa-1(21),6(24),7,9,19,22-hexaen-18-one 11,11-dioxide (140 mg, $0.32 \mathrm{mmol})$ in THF (10 mL), was added borane dimethylsulfide complex (1 M in THF, 0.32 $\mathrm{mL}, 0.32 \mathrm{mmol}$ ). The reaction was then stirred at $70^{\circ} \mathrm{C}$ for $16 \mathrm{~h}$. The reaction was quenched with $4 \mathrm{M}$ hydrochloric acid in dioxane $(3 \mathrm{~mL})$ and stirred for $20 \mathrm{mins}$ at room temperature. The mixture was then concentrated under reduced pressure, diluted with water $(6 \mathrm{~mL})$ and washed with ethyl acetate $(3 \times 7$ $\mathrm{mL}$ ). The aqueous layer was then adjusted to $\mathrm{pH} 9$ using saturated sodium bicarbonate solution and extracted with ethyl acetate $(3 \times 10 \mathrm{~mL})$. The combined organic layers were washed with saturated brine $(10 \mathrm{~mL})$, dried over anhydrous sodium sulfate and concentrated under reduced pressure to yield and off-white gum. This was then purified by preparative TLC using 4\% methanol in DCM to yield the title compound (22 mg, 16\%) as a pale yellow solid. ${ }^{1} \mathrm{H}$ NMR (400 MHz, DMSO- $\left.d_{6}\right) \delta$ ppm 1.22-1.31 (m, 4 H), 1.98 (s, 3 H), 2.17 (br. s., 2 H), 2.97 (br. s., 2 H), 3.13 (s, 2 H), 3.68-3.74 (m, 2 H), 4.02 (s, 3 H), 4.30-4.36 (m, $2 \mathrm{H}), 6.46(\mathrm{~d}, J=8.0 \mathrm{~Hz}, 1 \mathrm{H}), 6.50(\mathrm{~s}, 1 \mathrm{H}), 6.68(\mathrm{~d}, J=8.0 \mathrm{~Hz}, 1 \mathrm{H}), 7.72(\mathrm{t}, J=4.9$ $\mathrm{Hz}, 1 \mathrm{H}), 8.00(\mathrm{~d}, J=2.6 \mathrm{~Hz}, 1 \mathrm{H}), 8.32(\mathrm{~d}, J=1.8 \mathrm{~Hz}, 1 \mathrm{H}) ; \mathrm{LCMS}\left(\right.$ Method A): $\mathrm{MH}^{+}\left(\mathrm{C}_{20} \mathrm{H}_{27} \mathrm{~N}_{4} \mathrm{O}_{4} \mathrm{~S}\right)$ mass required: 419 mass found: 419 , Rt $0.58 \mathrm{~min}, 100 \%$ by UV.

\section{$N$-(5-bromo-2-methoxypyridin-3-yl)methanesulfonamide, 49}<smiles>COc1ncc(Br)cc1NS(C)(=O)=O</smiles>

To a solution of 5-bromo-2-methoxypyridin-3-amine (10.0 g, $49.3 \mathrm{mmol})$ and pyridine $(4.78 \mathrm{~mL}, 59.1$ mmol) in acetonitrile $(200 \mathrm{~mL})$ stirred at $0{ }^{\circ} \mathrm{C}$, was added mesyl chloride $(4.61 \mathrm{~mL}, 59.1 \mathrm{mmol})$ into dropwise over $5 \mathrm{~min}$. The reaction mixture was warmed to room temperature and stirred for $16 \mathrm{~h}$. The reaction was then poured into ice water, the resulting precipitate filtered off and dried to yield the title compound (7.8 g, 56\%) as an off-white solid. ${ }^{1} \mathrm{H}$ NMR (400 MHz, $\left.\mathrm{CDCl}_{3}\right) \delta \mathrm{ppm} 3.04(\mathrm{~s}, 3 \mathrm{H}), 4.00$ (s, 
$3 \mathrm{H}$ ), 6.74 (br. s., $1 \mathrm{H}), 7.89$ (d, $J=2.2 \mathrm{~Hz}, 1 \mathrm{H}), 7.97$ (d, $J=2.2 \mathrm{~Hz}, 1 \mathrm{H}$ ); LCMS (Method C): $\mathrm{MH}^{+}$ $\left(\mathrm{C}_{7} \mathrm{H}_{10}{ }^{79} \mathrm{BrN}_{2} \mathrm{O}_{3} \mathrm{~S}\right)$ mass required: 281 mass found: 281 , Rt $3.08 \mathrm{~min}, 100 \%$ by $\mathrm{UV}$.

\section{4-(6-methoxy-5-(methylsulfonamido)pyridin-3-yl)-3,4-dihydro-2 $H$-benzo $[b][1,4]$ oxazine-6- carboxylic acid, $\mathbf{5 0}$}<smiles>COc1ncc(N2CCOc3ccc(C(=O)O)cc32)cc1NS(C)(=O)=O</smiles>

To a degassed solution of $N$-(5-bromo-2-methoxypyridin-3-yl)methanesulfonamide (3.49 g, 12.4 mmol), methyl 3,4-dihydro-2H-benzo[b][1,4]oxazine-6-carboxylate $(2.00 \mathrm{~g}, 10.4 \mathrm{mmol})$ and dicyclohexyl(2',6'-diisopropoxy-[1,1'-biphenyl]-2-yl)phosphine (1.93 g, $4.1 \mathrm{mmol})$ in 1,4-dioxane (80 $\mathrm{mL})$ stirred under argon, was added cesium carbonate $(10.12 \mathrm{~g}, 31.1 \mathrm{mmol})$ and $\operatorname{Pd}_{2}(\mathrm{dba})_{3}(1.90 \mathrm{~g}, 2.07$ mmol). The reaction vessel was sealed and the mixture was stirred at $100{ }^{\circ} \mathrm{C}$ for $24 \mathrm{~h}$. The mixture was diluted with water $(100 \mathrm{~mL})$ and extractred with ethyl acetate $(100 \mathrm{~mL})$. The organic layer was seperated, dried over anhydrous sodium sulfate, filtered and concentrated under reduced pressure to yield crude product as a brown gum. This was purified by column chromatography on silica using $40 \%$ ethyl acetate in hexane. The appropriate fractions were combined to yield the coupled product $(1.30 \mathrm{~g})$. To a solution of coupled product $(1.30 \mathrm{~g}, 3.3 \mathrm{mmol})$ in THF $(26 \mathrm{~mL})$, was added a solution of lithium hydroxide $(0.24 \mathrm{~g}, 9.9 \mathrm{mmol})$ in water $(13 \mathrm{~mL})$. The reaction was stirred at room temperature for $5 \mathrm{~h}$. The mixture was diluted with water $(10 \mathrm{~mL})$, washed with ethyl acetate $(2 \times 20 \mathrm{~mL})$. The aqueous layer was acidified with $1 \mathrm{M}$ aqueous hydrochloric acid to $\mathrm{pH} 4$ and extracted with ethyl acetate $(2 \times 25 \mathrm{~mL})$. The combined organic layers were dried over anhydrous sodium sulfate and concentrated under reduced pressure to yield the title compound (600 mg, $11 \%$ yield) as a white solid. ${ }^{1} \mathrm{H}$ NMR (400 $\mathrm{MHz}, \mathrm{CDCl}_{3}$ ) $\delta$ ppm 3.05 (s, $3 \mathrm{H}), 3.65-3.69$ (m, 2 H), 4.02 (s, $3 \mathrm{H}), 4.36-4.41$ (m, $2 \mathrm{H}), 6.79$ (s, $1 \mathrm{H}), 6.89$ (d, J = 8.3 $\mathrm{Hz}, 1 \mathrm{H}), 7.37(\mathrm{~d}, J=2.0 \mathrm{~Hz}, 1 \mathrm{H}), 7.47(\mathrm{dd}, J=8.3,2.0 \mathrm{~Hz}, 1 \mathrm{H}), 7.73(\mathrm{~d}, J=2.6 \mathrm{~Hz}, 1 \mathrm{H}), 7.81(\mathrm{~d}, J$ $=2.6 \mathrm{~Hz}, 1 \mathrm{H}$ ); LCMS (Method E): $\mathrm{MH}^{+}\left(\mathrm{C}_{16} \mathrm{H}_{18} \mathrm{~N}_{3} \mathrm{O}_{6} \mathrm{~S}\right.$ ) mass required: 380 mass found: 380, Rt 2.09 $\min , 99 \%$ by UV. 


\section{4-(6-methoxy-5-(methylsulfonamido)pyridin-3-yl)- $\mathrm{N}$-methyl-3,4-dihydro- $2 \mathrm{H}$ -}

benzo $[b][1,4]$ oxazine-6-carboxamide, 21<smiles>CNC(=O)c1ccc2c(c1)N(c1cnc(OC)c(NS(C)(=O)=O)c1)CCO2</smiles>

To a solution of 4-(6-methoxy-5-(methylsulfonamido)pyridin-3-yl)-3,4-dihydro- $2 \mathrm{H}$ benzo[b][1,4]oxazine-6-carboxylic acid (200 $\mathrm{mg}, 0.53 \mathrm{mmol}$ ), HATU (300 mg, $0.79 \mathrm{mmol}$ ) and DIPEA $(0.28 \mathrm{~mL}, 1.58 \mathrm{mmol})$ in DCM $(10 \mathrm{~mL})$ stirred at $0^{\circ} \mathrm{C}$, was added methylamine hydrochloride $(33.2$ $\mathrm{mg}, 0.79 \mathrm{mmol})$. The reaction was then stirred at room temperature for $16 \mathrm{~h}$. The mixture was diluted with DCM $(10 \mathrm{~mL})$, washed with saturated brine $(10 \mathrm{~mL})$ and water $(10 \mathrm{~mL})$. The organic portion was dried over anhydrous sodium sulfate and concentrated under reduced pressure to yield the crude product as a colourless gum. This was purified by column chromatography on silica using ethyl acetate. The appropriate fractions were combined concentrated under reduced pressure and freeze dried to yield the title compound ( $80 \mathrm{mg}, 38 \%$ ) as an off-white solid. ${ }^{1} \mathrm{H}$ NMR (400 MHz, DMSO- $\left.d_{6}\right) \delta \mathrm{ppm} 2.90(\mathrm{~d}, J=$ $4.8 \mathrm{~Hz}, 3 \mathrm{H}), 3.10$ (s, $3 \mathrm{H}), 3.66-3.75$ (m, $2 \mathrm{H}), 4.03$ (s, $3 \mathrm{H}), 4.35-4.39$ (m, $2 \mathrm{H}), 6.12-6.25$ (m, $1 \mathrm{H})$, $6.72(\mathrm{~s}, 1 \mathrm{H}), 6.89(\mathrm{~d}, J=8.3 \mathrm{~Hz}, 1 \mathrm{H}), 7.15(\mathrm{dd}, J=8.3,2.1 \mathrm{~Hz}, 1 \mathrm{H}), 7.19(\mathrm{~d}, J=2.1 \mathrm{~Hz}, 1 \mathrm{H}), 7.76$ $(\mathrm{d}, J=2.4 \mathrm{~Hz}, 1 \mathrm{H}), 7.81(\mathrm{~d}, J=2.4 \mathrm{~Hz}, 1 \mathrm{H})$; LCMS (Method A): $\mathrm{MH}^{+}\left(\mathrm{C}_{17} \mathrm{H}_{21} \mathrm{~N}_{4} \mathrm{O}_{5} \mathrm{~S}\right.$ ) mass required: 393 mass found: 393 , Rt $0.71 \mathrm{~min}, 100 \%$ by UV.

\section{$N$-(2-methoxy-5-(6-((methylamino)methyl)-2H-benzo[b][1,4]oxazin-4(3H)-yl)pyridin-3-}

\section{yl)methanesulfonamide, 16}<smiles>CNCc1ccc2c(c1)N(c1cnc(OC)c(NS(C)(=O)=O)c1)CCO2</smiles>

To a solution of 4-(6-methoxy-5-(methylsulfonamido)pyridin-3-yl)- $\mathrm{N}$-methyl-3,4-dihydro- $2 \mathrm{H}$ benzo[b][1,4] oxazine-6-carboxamide $(350 \mathrm{mg}, 0.89 \mathrm{mmol})$ in THF $(20 \mathrm{~mL})$ stirred under nitrogen, was added borane dimethylsulfide complex (1 M in THF, $2.68 \mathrm{~mL}, 2.68 \mathrm{mmol})$. The reaction mixture was then stirred at $65^{\circ} \mathrm{C}$ for $16 \mathrm{~h}$. The reaction mixture was then quenched with excess methanol and heated for a further $16 \mathrm{~h}$. at reflux. The mixture was concentrated under reduced pressure, water was added and extracted with $20 \%$ methanol in dichloromethane $(2 \times 10 \mathrm{~mL})$. The combined organic layers were 
concentrated under reduced pressure and the residue purified by preparative HPLC on a Kromasil column using 15-100\% Acetonitrile in $10 \mathrm{mM}$ ammonium bicarbonate. The appropriate fractions were combined, concentrated under reduced pressure and freeze dried to yield the title compound (40 mg, $11 \%$ ) as an off-white solid. ${ }^{1} \mathrm{H}$ NMR (400 MHz, DMSO- $\left.d_{6}\right) \delta$ ppm 2.24 (s, $3 \mathrm{H}$ ), 2.93 (s, $3 \mathrm{H}$ ), 3.51 (s, $2 \mathrm{H}), 3.60-3.65$ (m, $2 \mathrm{H}), 3.88$ (s, $3 \mathrm{H}), 4.22-4.28$ (m, $2 \mathrm{H}), 6.63$ (dd, $J=8.0,2.0 \mathrm{~Hz}, 1 \mathrm{H}), 6.67$ (d, $J=$ $2.0 \mathrm{~Hz}, 1 \mathrm{H}), 6.75(\mathrm{~d}, J=8.0 \mathrm{~Hz}, 1 \mathrm{H}), 7.48(\mathrm{~d}, J=2.4 \mathrm{~Hz}, 1 \mathrm{H}), 7.72(\mathrm{~d}, J=2.4 \mathrm{~Hz}, 1 \mathrm{H})$; LCMS (Method A): $\mathrm{MH}^{+}\left(\mathrm{C}_{17} \mathrm{H}_{23} \mathrm{~N}_{4} \mathrm{O}_{4} \mathrm{~S}\right)$ mass required: 379 mass found: 379 , Rt $0.54 \mathrm{~min}, 97 \%$ by UV.

\section{4-(6-methoxy-5-(methylsulfonamido)pyridin-3-yl)- $N, N$-dimethyl-3,4-dihydro-2H-}

benzo $[b][1,4]$ oxazine-6-carboxamide, 23<smiles>COc1ncc(N2CCOc3ccc(C(=O)N(C)C)cc32)cc1NS(C)(=O)=O</smiles>

To a solution of 4-(6-methoxy-5-(methylsulfonamido)pyridin-3-yl)-3,4-dihydro- $2 \mathrm{H}$ benzo[b][1,4]oxazine-6-carboxylic acid $\quad(400 \quad \mathrm{mg}, \quad 1.05 \quad \mathrm{mmol}), \quad$ 1-Ethyl-3-(3dimethylaminopropyl)carbodiimide (243 mg, $1.27 \mathrm{mmol}$ ), 1-hydroxybenzotriazole (194 mg, 1.27 mmol) and DIPEA $(0.55 \mathrm{~mL}, 3.16 \mathrm{mmol})$ in DCM $(20 \mathrm{~mL})$ at $0^{\circ} \mathrm{C}$, was added dimethylamine hydrochloride (129 mg, $1.58 \mathrm{mmol}$ ). The reaction was then stirred at room temperature for $16 \mathrm{~h}$. The reaction was diluted with DCM $(10 \mathrm{~mL})$, washed with saturated brine $(10 \mathrm{~mL})$ and water $(10 \mathrm{~mL})$, dried over anhydrous sodium sulfate and concentrated under reduced pressure to yield the crude product as a colourless gum. This was then purified by column chromatography on silica using hexane/ethyl acetate. The appropriate fractions were combined, concentrated under reduced pressure and freeze dried to yield the title compound $(200 \mathrm{mg}, 46 \%)$ as an off-white solid. ${ }^{1} \mathrm{H}$ NMR (400 MHz, DMSO- $\left.d_{6}\right) \delta \mathrm{ppm} 2.86$ (s, $6 \mathrm{H}), 3.07$ (s, $3 \mathrm{H}), 3.65-3.70(\mathrm{~m}, 2 \mathrm{H}), 3.93(\mathrm{~s}, 3 \mathrm{H}), 4.30-4.35(\mathrm{~m}, 2 \mathrm{H}), 6.57(\mathrm{~d}, J=1.9 \mathrm{~Hz}, 1 \mathrm{H})$, $6.73(\mathrm{dd}, J=8.1,2.0 \mathrm{~Hz}, 1 \mathrm{H}), 6.83(\mathrm{~d}, J=8.1 \mathrm{~Hz}, 1 \mathrm{H}), 7.59$ (d, $J=2.4 \mathrm{~Hz}, 1 \mathrm{H}), 7.94(\mathrm{~d}, J=2.5 \mathrm{~Hz}$, $1 \mathrm{H}$ ), 9.28 (br. s, $1 \mathrm{H}$ ); LCMS (Method A): $\mathrm{MH}^{+}\left(\mathrm{C}_{18} \mathrm{H}_{23} \mathrm{~N}_{4} \mathrm{O}_{5} \mathrm{~S}\right.$ ) mass required: 407 mass found: 407 , Rt $0.77 \mathrm{~min}, 100 \%$ by UV. 


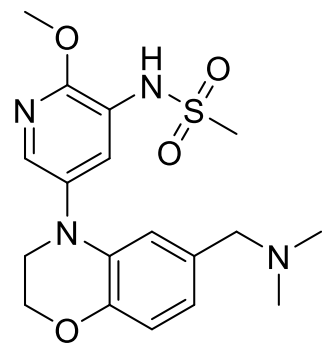

To a solution of 4-(6-methoxy-5-(methylsulfonamido)pyridin-3-yl)- $\mathrm{N}, \mathrm{N}$-dimethyl-3,4-dihydro- $2 \mathrm{H}$ benzo[b][1,4]oxazine-6-carboxamide $(80 \mathrm{mg}, 0.20 \mathrm{mmol})$ in THF $(10 \mathrm{~mL})$, was added borane dimethyl sulfide complex ( $1 \mathrm{M}$ in THF, $0.59 \mathrm{~mL}, 0.59 \mathrm{mmol})$. The reaction was stirred at $65{ }^{\circ} \mathrm{C}$ for $16 \mathrm{~h}$. Excess methanol was then added and the heated to reflux for $16 \mathrm{~h}$. The mixture was then concentrated under reduced pressure, water was added and extracted with $10 \%$ methanol in DCM $(2 \times 10 \mathrm{~mL})$. The combined organic layers were concentrted under reduced pressure to yield crude compound. This was purified by column chromatography on silica using $6 \%$ methanol in DCM. The appropriate fractions were combined to yield the title compound (20 mg, 26\%) as a white solid. ${ }^{1} \mathrm{H}$ NMR (400 $\mathrm{MHz}, \mathrm{CDCl}_{3}$ ) $\delta$ ppm 2.17 (br. s., 6H), 3.05 (s, 3H), 3.24 (br. s., 2H), 3.63-3.70 (m, 1H), 4.02 (s, 3H), 4.27-4.33 (m, 2H), $6.68(\mathrm{dd}, J=8.11,1.75 \mathrm{~Hz}, 1 \mathrm{H}), 6.71$ (br. s, 1H), $6.82(\mathrm{~d}, J=8.11 \mathrm{~Hz}, 1 \mathrm{H}), 7.71$ (d, $J=2.50 \mathrm{~Hz}$, 1H), $7.83(\mathrm{~d}, J=2.41 \mathrm{~Hz}, 1 \mathrm{H}) ;{ }^{13} \mathrm{C}$ NMR $\left(101 \mathrm{MHz}, \mathrm{CDCl}_{3}\right) \delta \mathrm{ppm} 29.6,44.9(2 \mathrm{C}), 49.4,54.8,63.6$, 64.1, 116.8, 117.2, 121.9, 122.2, 130.7 131.6, 135.9, 138.1, 144.4, 146.9, 155.7; LCMS (Method A): $\mathrm{MH}^{+}\left(\mathrm{C}_{18} \mathrm{H}_{25} \mathrm{~N}_{4} \mathrm{O}_{4} \mathrm{~S}\right)$ mass required: 393 mass found: 393, Rt $0.55 \mathrm{~min}, 98 \%$ by UV; HRMS exact mass calculated for $[\mathrm{M}+\mathrm{H}]^{+}\left(\mathrm{C}_{18} \mathrm{H}_{25} \mathrm{~N}_{4} \mathrm{O}_{4} \mathrm{~S}\right)$ requires $\mathrm{m} / z$ 393.1597, found 393.1595.

benzyl (2-( $N$-(5-bromo-2-methoxypyridin-3-yl)sulfamoyl)ethyl)(methyl)carbamate, 31<smiles>COc1ncc(Br)cc1NS(=O)(=O)CCN(C)C(=O)OCc1ccccc1</smiles>

To a solution of 2-(((benzyloxy)carbonyl)(methyl)amino)ethanesulfonic acid (11.0 g, $40.2 \mathrm{mmol})$ in toluene $(110 \mathrm{~mL})$ stirred under nitrogen at $0^{\circ} \mathrm{C}$ was added thionyl chloride $(2.94 \mathrm{~mL}, 40.2 \mathrm{mmol})$. The reaction mixture was stirred at $110{ }^{\circ} \mathrm{C}$ for $16 \mathrm{hr}$. The reaction mixture was poured into ice cold water $(5 \mathrm{~mL})$, extracted with dichloromethane $(2 \mathrm{x} 10 \mathrm{~mL})$, The combined organic phase was washed with water $(10 \mathrm{~mL})$, brine wash $(10 \mathrm{~mL})$ and dried over sodium sulphate and evaporated in vacuo to give cude benzyl (2-(chlorosulfonyl)ethyl)(methyl)carbamate as a black gum (11.0 g). To a solution of benzyl (2-(chlorosulfonyl)ethyl)(methyl)carbamate $(11.0 \mathrm{~g}, 37.7 \mathrm{mmol})$ in pyridine $(110 \mathrm{~mL})$ at $5{ }^{\circ} \mathrm{C}$, 
was added 5-bromo-2-methoxypyridin- 3-amine $(7.66 \mathrm{~g}, 37.7 \mathrm{mmol})$. The reaction was then stirred at room temperature for $12 \mathrm{~h}$. The mixture was concentrated under reduced pressure and the residue was dissolved in water $(200 \mathrm{~mL})$ and extracted with ethyl acetate $(2 \times 200 \mathrm{~mL})$. The combined organic layers were dried over anhydrous sodium sulfate and concentrated under reduced pressure to get the crude compound. This was purified by column chromatography on silica using a 0-40\% ethyl acetate in hexane gradient. The appropriate fractions were combined and concentrated under reduced pressure to yield the title compound (3.8 g, 21\%). ${ }^{1} \mathrm{H}$ NMR (400 MHz, $\left.\mathrm{CDCl}_{3}\right) \delta$ ppm 2.97 (br. s., $3 \mathrm{H}$ ), 3.23-3.35 (m, 2 H), 3.69-3.82 (m, 2 H), 4.00 (s, 3 H), 4.85-5.19 (m, 2 H), 6.66 (br. s., 1 H), 7.28-7.40 (m, 5 H), 7.89 (br. s., $1 \mathrm{H}$ ), 7.97 (s, $1 \mathrm{H}$ ); LCMS (Method C): $\mathrm{MH}^{+}\left(\mathrm{C}_{17} \mathrm{H}_{22} \mathrm{BrN}_{3} \mathrm{O}_{5} \mathrm{~S}\right.$ ) mass required: 457 mass found: 457, Rt 3.39 min, $96 \%$ by UV.

\section{4-(5-(2-(((benzyloxy)carbonyl)(methyl)amino)ethylsulfonamido)-6-methoxypyridin-3-yl)-3,4- dihydro-2H-benzo[b][1,4]oxazine-6-carboxylic acid, 51}

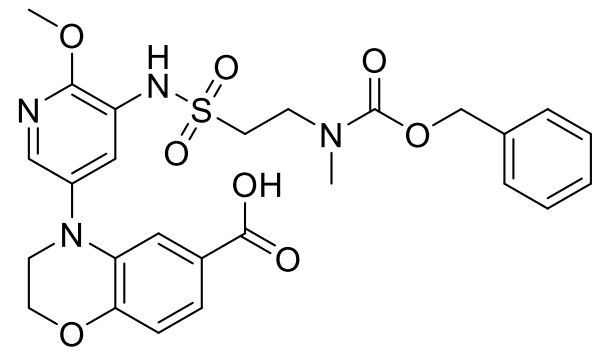

To a solution of methyl 3,4-dihydro- $2 H$-benzo[b][1,4] oxazine-6-carboxylate $(1.5 \mathrm{~g}, 7.76 \mathrm{mmol})$ in 1,4dioxane $(100 \mathrm{~mL})$, was added benzyl (2-(N-(5-bromo-2-methoxypyridin-3yl)sulfamoyl)ethyl)(methyl)carbamate (3.56 g, $7.76 \mathrm{mmol})$ and cesium carbonate $(7.59 \mathrm{~g}, 23.29 \mathrm{mmol})$. The mixture was degassed for $30 \mathrm{~min}$. Then $\mathrm{Pd}_{2}(\mathrm{dba})_{3}(1.42 \mathrm{~g}, 1.55 \mathrm{mmol})$ and RuPhos (1.45 g, 3.11 mmol) was added and the reaction stirred at $110{ }^{\circ} \mathrm{C}$ for $16 \mathrm{~h}$. in a sealed tube. The mixture was filtered through celite and washed with ethyl acetate. The filtrate was concentrated under reduced pressure to yield the crude product. This was purified by column chromatography on silica using $30 \%$ ethyl acetate in hexane. The appropriate fractions were combined and concentrated under reduced pressure to afford the coupled product ( $1.40 \mathrm{~g}, 25.3 \%$ yield). Additional coupled product was obtained through similar reactions. To a solution of couplded product $(8.0 \mathrm{~g}, 14.0 \mathrm{mmol})$ in THF $(100 \mathrm{~mL})$ and water $(100 \mathrm{~mL})$ at $0{ }^{\circ} \mathrm{C}$, was added lithium hydroxide $(2.94 \mathrm{~g}, 70.1 \mathrm{mmol})$ The reaction was then stirred at room temperature for $48 \mathrm{~h}$. The mixture was then concentrated under reduced pressure, water $(100 \mathrm{~mL})$ was added and washed with ethyl acetate $(2 \times 50 \mathrm{~mL})$. The aqueous phase was then acidified with $1 \mathrm{M}$ aqueous hydrochloric acid to $\mathrm{pH} 2$ and extracted with DCM $(2 \times 200 \mathrm{~mL})$. The combined organic layer was dried over anhydrous sodium sulfate and concentrated under reduced pressure to yield the title compound $(6.0 \mathrm{~g}, 69 \%)$ as a black solid. ${ }^{1} \mathrm{H}$ NMR (400 MHz, DMSO- $\left.d_{6}\right) \delta \mathrm{ppm} 2.82-2.91(\mathrm{~m}, 3 \mathrm{H})$, 3.41 (t, $J=6.7$ Hz, 2 H), 3.66 (br. s., 4 H), 3.92 (m, 3 H), 4.35 (br. s., 2 H), 5.04 (br. s., 2 H), 6.88 (d, $J$ 
$=8.2 \mathrm{~Hz}, 1 \mathrm{H}), 7.16(\mathrm{~d}, J=2.0 \mathrm{~Hz}, 1 \mathrm{H}), 7.23-7.44(\mathrm{~m}, 6 \mathrm{H}), 7.63$ (br. s., $1 \mathrm{H}), 7.96$ (br. s., $1 \mathrm{H}), 9.43$

(br. s., $1 \mathrm{H}$ ), 12.36 (br. s., $1 \mathrm{H}$ ) ; LCMS (Method C): $\mathrm{MH}^{+}\left(\mathrm{C}_{26} \mathrm{H}_{29} \mathrm{~N}_{4} \mathrm{O}_{8} \mathrm{~S}\right.$ ) mass required: 557 mass found: 557, Rt $2.92 \mathrm{~min}, 91 \%$ by UV.

4-(6-methoxy-5-(2-(methylamino)ethylsulfonamido)pyridin-3-yl)-3,4-dihydro-2Hbenzo $[b][1,4]$ oxazine-6-carboxylic acid, 33<smiles>CNCCS(=O)(=O)Nc1cc(N2CCOc3ccc(C(=O)O)cc32)cnc1OC</smiles>

To a solution of 4-(5-(2-(((benzyloxy)carbonyl)(methyl)amino)ethylsulfonamido)-6-methoxypyridin3-yl)-3,4-dihydro-2H-benzo[b][1,4]oxazine-6-carboxylic acid $(6.0 \mathrm{~g}, 10.78 \mathrm{mmol})$, in THF (125 mL) and ethyl acetate $(125 \mathrm{~mL})$ stirred under nitrogen at room temp was added palladium on carbon (5.74 $\mathrm{g}, 53.9 \mathrm{mmol}$ ) portion wise. The reaction mixture was stirred at room temperature under an atmosphere of hydrogen for $36 \mathrm{~h}$. The mixture was filtered through celite and washed with THF (500 mL). The filterate was concentrated under reduced pressure to yield the title compound ( $3.0 \mathrm{~g}, 64.1 \%$ yield) as an off white solid. ${ }^{1} \mathrm{H}$ NMR (400 MHz, DMSO- $d_{6}$ ) $\delta$ ppm 2.56 (s, 3H), 3.15 (app. s, 4H), 3.59-3.64 (m, 2H), $3.88(\mathrm{~s}, 3 \mathrm{H}), 4.32-4.37(\mathrm{~m}, 2 \mathrm{H}), 6.82(\mathrm{~d}, J=8.1 \mathrm{~Hz}, 1 \mathrm{H}), 7.14$ (d, $J=2.0 \mathrm{~Hz}, 1 \mathrm{H}), 7.23$ (dd, $J=$ 8.2, $2.0 \mathrm{~Hz}, 1 \mathrm{H}), 7.27(\mathrm{~d}, J=2.4 \mathrm{~Hz}, 1 \mathrm{H}), 7.48$ (d, $J=2.4 \mathrm{~Hz}, 1 \mathrm{H})$; LCMS (Method A): $\mathrm{MH}^{+}$ $\left(\mathrm{C}_{18} \mathrm{H}_{23} \mathrm{~N}_{4} \mathrm{O}_{6} \mathrm{~S}\right)$ mass required: 423 mass found: 423 , Rt $1.47 \mathrm{~min}, 97 \%$ by $\mathrm{UV}$.

\section{9-Methoxy-15-methyl-2-oxa-12-thia-5,8,11,15-tetraazatetracyclo[15.2.2.16,(10),0(20,5)]docosa-} 6,8,10(22),17,19,20-hexaen-16-one 12.12-dioxide, 24<smiles>COc1ncc(N2CCOc3ccc(C(=O)N4CCS(=O)(=O)C4)cc32)cc1N</smiles>

To a suspension of methanesulfonyl chloride $(0.18 \mathrm{~mL}, 2.37 \mathrm{mmol})$ and 1-methyl- $1 H$-imidazole $(0.76$ $\mathrm{mL}, 9.47 \mathrm{mmol})$ in DCM $(40 \mathrm{~mL})$ stirred under nitrogen at $0{ }^{\circ} \mathrm{C}$ was added 4-(6-methoxy-5-(2(methylamino)ethylsulfonamido)pyridin-3-yl)-3,4-dihydro-2H-benzo[b][1,4]oxazine-6-carboxylic 
acid $(1.00 \mathrm{~g}, 2.37 \mathrm{mmol})$. The reaction was then stirred at room temperature for $4 \mathrm{~h}$. Saturated ammonium chloride solution $(15 \mathrm{~mL})$ was added and the mixture extracted with DCM $(2 \times 15 \mathrm{~mL})$. The combined organic layer was dried over anhydrous sodium sulfate and concentrated under reduced pressure to yield crude product $(1.2 \mathrm{~g})$ as black gum. This was purified by column chromatography on silica using a 0-2\% methanol in DCM gradient. The appropriate fractions were combined and concentrated under reduced pressure to yield the title compound $(230 \mathrm{mg}, 21 \%)$ as an off-white solid. ${ }^{1} \mathrm{H}$ NMR (400 MHz, DMSO- $d_{6}$ ) $\delta$ ppm 2.87 (s, $3 \mathrm{H}$ ), 3.60 (br. s., $2 \mathrm{H}$ ), 3.70-3.76 (m, $2 \mathrm{H}$ ), 3.77-3.82 (m, 2 H), 3.90 (s, 3 H), 4.27-4.33 (m, 2 H), $6.80(\mathrm{dd}, J=8.2,2.0 \mathrm{~Hz}, 1 \mathrm{H}), 6.92(\mathrm{~d}, J=8.2 \mathrm{~Hz}, 1 \mathrm{H})$, $7.14(\mathrm{~d}, J=2.0 \mathrm{~Hz}, 1 \mathrm{H}), 7.70(\mathrm{~d}, J=2.2 \mathrm{~Hz}, 1 \mathrm{H}), 7.79$ (d, $J=2.4 \mathrm{~Hz}, 1 \mathrm{H}), 9.93$ (s, $1 \mathrm{H})$; LCMS (Method D): $\mathrm{MH}^{+}\left(\mathrm{C}_{18} \mathrm{H}_{21} \mathrm{~N}_{4} \mathrm{O}_{5} \mathrm{~S}\right)$ mass required: 405 mass found: 405, Rt $1.76 \mathrm{~min}, 88 \%$ by UV.

\section{9-Methoxy-15-methyl-2-oxa-12-thia-5,8,11,15-tetraazatetracyclo[15.2.2.16,(10),0(20,5)]docosa- 6,8,10(22),17,19,20-hexaene 12.12-dioxide, 19}<smiles>COc1ncc(N2CCOc3ccc(CN4CCS(=O)(=O)C4)cc32)cc1N</smiles>

To

a solution

of

9-methoxy-15-methyl-2-oxa-12-thia-5,8,11,15tetraazatetracyclo[15.2.2.16,(10),0(20,5)]docosa-6,8,10(22),17,19,20-hexaen-16-one 12.12-dioxide (200 mg, $0.495 \mathrm{mmol})$ in THF (20 mL), was added borane dimethyl sulfide complex (2 M in THF, $1.236 \mathrm{~mL}, 2.473 \mathrm{mmol})$. The reaction was then stirred at $80^{\circ} \mathrm{C}$ for $4 \mathrm{~h}$. The mixture was quenched with methanol $(2 \mathrm{~mL})$ at room temperature and heated at $80{ }^{\circ} \mathrm{C}$ for a further $16 \mathrm{~h}$. The mixture was then concentrated under reduced pressure to yield crude product $(300 \mathrm{mg}$ ). This was then purified by column chromatography on silica using 0-1\% methanol in DCM. The appropriate fractions were combined and concentrated under reduced pressure to yield the title compound $(20 \mathrm{mg}, 10 \%)$ as an off-white solid. ${ }^{1} \mathrm{H}$ NMR (400 MHz, DMSO-d6) $\delta$ ppm 2.31 (s, 3 H), 2.53-2.60 (m, 2 H), 3.39-3.51 (m, 4 H), 3.69-3.77 (m, $2 \mathrm{H}), 3.89$ (s, $3 \mathrm{H}), 4.18-4.25(\mathrm{~m}, 2 \mathrm{H}), 6.58(\mathrm{dd}, \mathrm{J}=8.1,1.5 \mathrm{~Hz}, 1 \mathrm{H}), 6.78(\mathrm{~d}, \mathrm{~J}=8.1 \mathrm{~Hz}, 1 \mathrm{H})$, $6.99(\mathrm{~d}, \mathrm{~J}=1.5 \mathrm{~Hz}, 1 \mathrm{H}), 7.55(\mathrm{~d}, \mathrm{~J}=2.4 \mathrm{~Hz}, 1 \mathrm{H}), 7.81$ (d, J = 2.4 Hz, $1 \mathrm{H}), 9.52$ (br. s., $1 \mathrm{H}) ;{ }^{13} \mathrm{C}$ NMR (176 MHz, DMSO-d6) $\delta$ ppm 43.0, 47.7, 49.2, 49.8, 53.5, 59.3, 63.9, 117.1, 119.7, 120.1, 122.1, 130.4, 131.2, 133.5, 138.4 (2C), 144.5, 149.6; LCMS (Method A): $\mathrm{MH}^{+}\left(\mathrm{C}_{18} \mathrm{H}_{23} \mathrm{~N}_{4} \mathrm{O}_{4} \mathrm{~S}\right.$ ) mass required: 391 mass found: 391, Rt 0.57 min, $99 \%$ by UV; HRMS exact mass calculated for $[\mathrm{M}+\mathrm{H}]^{+}\left(\mathrm{C}_{18} \mathrm{H}_{23} \mathrm{~N}_{4} \mathrm{O}_{4} \mathrm{~S}\right)$ requires $\mathrm{m} / \mathrm{z} 391.1440$, found 391.1448 . 


\section{$N$-(5-Bromo-2-methoxypyridin-3-yl)-3-(1,3-dioxoisoindolin-2-yl)propane-1-sulfonamide, 52}

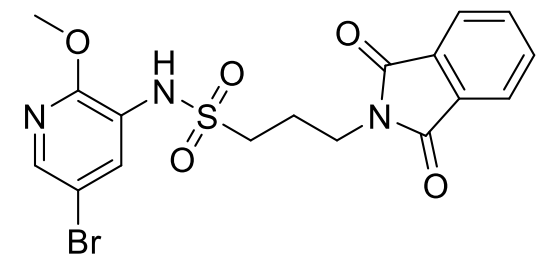

Chemical Formula: $\mathrm{C}_{17} \mathrm{H}_{16} \mathrm{BrN}_{3} \mathrm{O}_{5} \mathrm{~S}$

To a solution of pyridine (6.9 g, $87 \mathrm{mmol}), 3$-(1,3-dioxoisoindolin-2-yl)propane-1-sulfonyl chloride (5.0 g, $17 \mathrm{mmol})$ in DCM (40 mL), was added 5-bromo-2-methoxypyridin-3-amine (3.5 g, $17 \mathrm{mmol})$. The reaction mixture was then stirred at room temperature for 18 hours. The reaction was quenched with water $(50 \mathrm{~mL})$, and the organic phase separated and dried over a hydrophobic frit. The solvent was then removed in vacuo, the residue was loaded preabsorbed on florisil and purified by column chromatography on silica $80 \mathrm{~g}$ using a $0-100 \%$ ethyl acetate/cyclohexane gradient. The appropriate fractions were combined and concentrated in vacuo to give the title compound ( $2.3 \mathrm{~g}, 29 \%$ yield) as an off-white solid. ${ }^{1} \mathrm{H}$ NMR (400 MHz, $\mathrm{CDCl}_{3}$ ) $\delta 2.18-2.27$ (m, 2H), 3.17-3.23 (m, 2H), $3.82(\mathrm{t}, J=6.6$ Hz, 2H), 4.01 (s, 3H), 6.71 (s, 1H), 7.76 (dd, $J=5.5,3.1 \mathrm{~Hz}, 2 \mathrm{H}), 7.83-7.89$ (m, 4H); LCMS (Method A): $\mathrm{MH}^{+}\left(\mathrm{C}_{17} \mathrm{H}_{17} \mathrm{BrN}_{3} \mathrm{O}_{5} \mathrm{~S}\right)$ mass required: 454, 456 mass found: 454, 456, Rt 1.09 min, $95 \%$ by UV.

Methyl 4-(5-(3-(1,3-dioxoisoindolin-2-yl)propylsulfonamido)-6-methoxypyridin-3-yl)-3,4dihydro-2H-benzo $[b][1,4]$ oxazine-6-carboxylate, 53<smiles>COC(=O)c1ccc2c(c1)N(c1cnc(OC)c(NS(=O)(=O)CCCN3C(=O)c4ccccc4C3=O)c1)CCO2</smiles>

To caesium carbonate $(4.3 \mathrm{~g}, 13 \mathrm{mmol})$, RuPhos Pd G2 (0.68 g, $0.9 \mathrm{mmol})$, methyl 3,4-dihydro- $2 \mathrm{H}$ benzo[b][1,4]oxazine-6-carboxylate $(0.85 \mathrm{~g}, 4.4 \mathrm{mmol})$ and dicyclohexyl(2',6'-diisopropoxy-[1,1'biphenyl]-2-yl)phosphane $(0.82 \mathrm{~g}, 1.7 \mathrm{mmol})$ in a sealed degassed vial, was added a solution of $N-(5-$ bromo-2-methoxypyridin-3-yl)-3-(1,3-dioxoisoindolin-2-yl)propane-1-sulfonamide (2.0 g, $4.4 \mathrm{mmol})$ in dry 1,4-dioxane $(15 \mathrm{~mL})$. The reaction mixture was heated under microwave conditions to $140{ }^{\circ} \mathrm{C}$ for 3 hours. The reaction mixture was filtered through celite and washed with methanol $(50 \mathrm{~mL})$. The solvent was then removed in vacuo. The residue was dissolved in water $(20 \mathrm{~mL})$, extracted with ethyl acetate $(20 \mathrm{~mL})$ and washed with further ethyl acetate $(20 \mathrm{~mL})$. The solvent was then removed in vacuo and the residue was loaded preabsorbed on florisil and purified by column chromatography on silica using a $0-100 \%$ ethyl acetate/cyclohexane gradient. This yielded the title compound (1.74 g, $70 \%$ yield) 
as a clear oil. $v_{\max } / \mathrm{cm}^{-1}$ (neat) $1709,1771,2931 ;{ }^{1} \mathrm{H} \mathrm{NMR}\left(400 \mathrm{MHz}, \mathrm{CDCl}_{3}\right) \delta 2.21-2.29(\mathrm{~m}, 2 \mathrm{H}), 3.22-$ $3.28(\mathrm{~m}, 2 \mathrm{H}), 3.67-3.72(\mathrm{~m}, 2 \mathrm{H}), 3.81(\mathrm{~s}, 3 \mathrm{H}), 3.86(\mathrm{t}, J=6.7 \mathrm{~Hz}, 2 \mathrm{H}), 4.05(\mathrm{~s}, 3 \mathrm{H}), 4.38-4.42(\mathrm{~m}$, 2H), $6.76(\mathrm{~s}, 1 \mathrm{H}), 6.91(\mathrm{~d}, J=8.3 \mathrm{~Hz}, 1 \mathrm{H}), 7.40(\mathrm{~d}, J=2.0 \mathrm{~Hz}, 1 \mathrm{H}), 7.47(\mathrm{dd}, J=8.3,2.0 \mathrm{~Hz}, 1 \mathrm{H})$, 7.72-7.76 (m, 3H), 7.80-7.86 (m, 3H); LCMS (Method A): $\mathrm{MH}^{+}\left(\mathrm{C}_{27} \mathrm{H}_{27} \mathrm{~N}_{4} \mathrm{O}_{8} \mathrm{~S}\right.$ ) mass required: 567 mass found: 567 , Rt 1.17 min, $90 \%$ by UV.

\section{9-Methoxy-2-oxa-12-thia-5,8,11,16-tetraazatetracyclo[16.2.2.16,(10),0(20,5)]tricosa-} 1(20),6(23),7,9,18,21-hexaen-17-one 12,12-dioxide, 22<smiles></smiles>

To a solution of methyl 4-(5-((3-(1,3-dioxoisoindolin-2-yl)propyl)sulfonamido)-6-methoxypyridin-3yl)-3,4-dihydro-2 $H$-benzo[b][1,4]oxazine-6-carboxylate $(220 \mathrm{mg}, 0.4 \mathrm{mmol})$ in ethanol $(25 \mathrm{~mL})$ and water $(25 \mathrm{~mL})$, was added lithium hydroxide $(190 \mathrm{mg}, 7.8 \mathrm{mmol})$. The reaction mixture was then heated at reflux for 4 days. The solvent was then removed in vacuo. The residue was loaded in water onto an isolute-103 cartridge. The cartridge was washed with water $(50 \mathrm{~mL})$, followed by methanol $(50 \mathrm{~mL})$. The methanol containing portion was then concentrated in vacuo to yield a white solid (124 mg). To a solution of white solid (50 mg, $0.12 \mathrm{mmol}$ ) in DMF (10 mL), was added HATU (45.0 mg, $0.12 \mathrm{mmol}$ ) and DIPEA $(0.04 \mathrm{~mL}, 0.24 \mathrm{mmol})$. The reaction mixture was then stirred at room temperature for 3 days. The solvent was removed in vacuo and the residue was dissolved in DMSO and purified by mass directed HPLC on Sunfire C18 column using acetonitrile/water with a formic acid modifier. The solvent was removed in vacuo to give the title compound ( $2 \mathrm{mg}, 4 \%$ yield) as an off-white solid. $v_{\max } / \mathrm{cm}^{-1}$ (neat) $1606,1711,2935 ;{ }^{1} \mathrm{H}$ NMR (400 MHz, DMSO-d $\left.d_{6}\right) \delta{ }^{1} \mathrm{H}$ NMR (400 MHz, $\mathrm{CDCl}_{3}$ ) $\delta 2.33$ (quin, $J=6.2$ $\mathrm{Hz}, 2 \mathrm{H}), 3.33$ (t, $J=5.9 \mathrm{~Hz}, 2 \mathrm{H}), 3.54$ (app. q, $J=6.4 \mathrm{~Hz}, 2 \mathrm{H}), 3.76-3.82(\mathrm{~m}, 2 \mathrm{H}), 4.05(\mathrm{~s}, 3 \mathrm{H}), 4.45-$ $4.54(\mathrm{~m}, 2 \mathrm{H}), 6.91(\mathrm{~d}, J=8.2 \mathrm{~Hz}, 2 \mathrm{H}), 7.14(\mathrm{dd}, J=8.2,2.1 \mathrm{~Hz}, 1 \mathrm{H}), 7.20(\mathrm{~d}, J=2.1 \mathrm{~Hz}, 1 \mathrm{H}), 7.74$ $(\mathrm{d}, J=2.7 \mathrm{~Hz}, 1 \mathrm{H}), 8.25(\mathrm{~d}, J=2.7 \mathrm{~Hz}, 1 \mathrm{H}) ; \mathrm{LCMS}$ (Method A): $\mathrm{MH}^{+}\left(\mathrm{C}_{18} \mathrm{H}_{21} \mathrm{~N}_{4} \mathrm{O}_{5} \mathrm{~S}\right.$ ) mass required: 405 mass found: 405 , Rt $0.81 \mathrm{~min}, 98 \%$ by UV. 


\section{9-Methoxy-2-oxa-12-thia-5,8,11,16-tetraazatetracyclo[16.2.2.16,(10),0(20,5)]tricosa-}

1(20),6(23),7,9,18,21-hexaene 12,12-dioxide, 17<smiles>COc1ncc(N2C=CC3=CC=C(NS(=O)(=O)CCCNC3)OCC2)cc1NS</smiles>

To a solution of 26-methoxy-13,14-dihydro-12H-4-thia-3,8-diaza-1(4,6)-benzo[b][1,4] oxazina-2(3,5)pyridinacyclononaphan-9-one 4,4-dioxide $(2.0 \mathrm{mg}, 0.005 \mathrm{mmol})$ in THF $(0.5 \mathrm{~mL})$ was added $2 \mathrm{M}$ DIBAL-H in THF $(0.015 \mathrm{~mL}, 0.030 \mathrm{mmol})$. the mixture was then stirred at room temperature for 6 hours. The reaction was then quenched with $1 \mathrm{M}$ aqueous potassium sodium tartrate $(1 \mathrm{~mL})$ and extracted with DCM $(1 \mathrm{~mL})$. The solvent was then removed in vacuo. The residue was dissolved in DMSO and purified by mass directed HPLC on an Xbridge column using acetonitrile:water with an ammonium carbonate modifier. The solvent was removed in vacuo to give the title compound $(1.2 \mathrm{mg}$, $62 \%$ ) as a clear oil. ${ }^{1} \mathrm{H}$ NMR (400 MHz, MeOD) $\delta 1.70$ (quin, $J=7.0 \mathrm{~Hz}, 2 \mathrm{H}$ ), $2.71(\mathrm{t}, J=7.5 \mathrm{~Hz}$, $2 \mathrm{H}), 3.28(\mathrm{t}, J=6.0 \mathrm{~Hz}, 2 \mathrm{H}), 3.77-3.82(\mathrm{~m}, 2 \mathrm{H}), 3.89(\mathrm{~s}, 2 \mathrm{H}), 4.07(\mathrm{~s}, 3 \mathrm{H}), 4.27-4.31(\mathrm{~m}, 2 \mathrm{H}), 6.76$ $(\mathrm{dd}, J=8.0,1.8 \mathrm{~Hz}, 1 \mathrm{H}), 6.86-6.91(\mathrm{~m}, 1 \mathrm{H}), 6.89(\mathrm{~d}, J=8.0 \mathrm{~Hz}, 1 \mathrm{H}), 8.09(\mathrm{~d}, J=2.6 \mathrm{~Hz}, 1 \mathrm{H}), 8.29$ $(\mathrm{d}, J=2.5 \mathrm{~Hz}, 1 \mathrm{H})$; LCMS (Method A): $\mathrm{MH}^{+}\left(\mathrm{C}_{18} \mathrm{H}_{23} \mathrm{~N}_{4} \mathrm{O}_{4} \mathrm{~S}\right.$ ) mass required: 391 mass found: 391, Rt $0.42 \mathrm{~min}, 92 \%$ by UV.

\section{tert-butyl (5-bromo-2-methoxypyridin-3-yl)carbamate, 54}<smiles>COc1ncc(Br)cc1NC(=O)OC(C)(C)C</smiles>

To a solution of 5-bromo-2-methoxypyridin-3-amine (5.0 g, $24.6 \mathrm{mmol})$ in THF (100 mL) stirred under nitrogen at $-78{ }^{\circ} \mathrm{C}$, was added sodium bis(trimethylsilyl)amide $(9.0 \mathrm{~g}, 49.3 \mathrm{mmol})$ and di-tert-butyl dicarbonate $(8.58 \mathrm{~mL}, 36.9 \mathrm{mmol})$. The reaction was then stirred at room temperature for $16 \mathrm{~h}$. The reaction was quenched with saturated aqueous ammonium chloride $(100 \mathrm{~mL})$ and extracted with ethyl acetate $(2 \times 50 \mathrm{~mL})$. The combined organic portions were dried over anhydrous sodium sulfate and concentrated under reduced pressure to yield the crude product as brown liquid. This was purified by column chromatography on silica using a $0-5 \%$ ethyl acetae in hexane gradient. The appropriate fractions were concentrated under reduced pressure to yield the title compound $(3.0 \mathrm{~g}, 40 \%)$ as a colourless liquid. ${ }^{1} \mathrm{H}$ NMR (400 MHz, DMSO- $d_{6}$ ) $\delta$ ppm 1.52 (s, $9 \mathrm{H}$ ), 3.97 (s, $3 \mathrm{H}$ ), 7.81 (d, $J=2.2$ $\mathrm{Hz}, 1 \mathrm{H}), 8.33-8.57$ (m, $1 \mathrm{H})$. 


\section{3,4-dihydro-2H-benzo[b][1,4] ]oxazine-6-carboxylic acid, 55}<smiles>O=C(O)c1ccc2c(c1)NCCO2</smiles>

To a solution of methyl 3,4-dihydro- $2 H$-benzo[b][1,4]oxazine-6-carboxylate $(13.0 \mathrm{~g}, 67.3 \mathrm{mmol})$ in THF $(130 \mathrm{~mL})$ and water $(130 \mathrm{~mL})$ at $0^{\circ} \mathrm{C}$, was added lithium hydroxide $(4.83 \mathrm{~g}, 202 \mathrm{mmol})$. The reaction was then stirred at room temperature for $36 \mathrm{~h}$. The mixture was concentrted under reduced pressure, the residue was dissolved in water $(50 \mathrm{~mL})$ and washed with ethyl acetate $(2 \times 250 \mathrm{~mL})$. The aqueous layer was acidified with $1 \mathrm{M}$ aqueous hydrochloric acid and extrtracted with ethyl acetate $(2 \mathrm{x}$ $500 \mathrm{~mL}$ ). The combined organic layers were dried over anhydrous sodium sulfate and concentrated under reduced pressure to yield the title compound $\left(9.0 \mathrm{~g}, 75 \%\right.$ yield) as red solid. ${ }^{1} \mathrm{H}$ NMR (400 MHz, DMSO- $\left.d_{6}\right) \delta$ ppm 3.34-3.55 (m, $\left.2 \mathrm{H}\right), 4.26-4.40(\mathrm{~m}, 2 \mathrm{H}), 6.79(\mathrm{~d}, J=8.3 \mathrm{~Hz}, 1 \mathrm{H}), 7.33(\mathrm{~d}, J=1.8 \mathrm{~Hz}$, $1 \mathrm{H}), 7.43$ (dd, $J=8.4,1.8 \mathrm{~Hz}, 1 \mathrm{H}$ ); LCMS (Method C): $\mathrm{MH}^{+}\left(\mathrm{C}_{9} \mathrm{H}_{10} \mathrm{NO}_{3}\right.$ ) mass required: 180 mass found: 180 , Rt $1.11 \mathrm{~min}, 86 \%$ by UV.

tert-butyl (5-(6-(allyl(methyl)carbamoyl)-2H-benzo[b][1,4]oxazin-4(3H)-yl)-2-methoxypyridin-3yl)carbamate, 56<smiles>C=CCN(C)C(=O)c1ccc2c(c1)N(c1cnc(OC)c(NC(=O)OC(C)(C)C)c1)CCO2</smiles>

To a solution of 3,4-dihydro-2 $\mathrm{H}$-benzo[b][1,4]oxazine-6-carboxylic acid $(9.00 \mathrm{~g}, 50.2 \mathrm{mmol})$ and $\mathrm{N}$ methylprop-2-en-1-amine (4.29 g, $60.3 \mathrm{mmol})$ in DCM (100 mL), was added HATU (22.92 g, 60.3 mmol). The mixture was then cooled to $0{ }^{\circ} \mathrm{C}$ and DIPEA $(26.3 \mathrm{~mL}, 151 \mathrm{mmol})$ was added. The reaction was then stirred at room temperature for $24 \mathrm{~h}$. Water $(500 \mathrm{~mL})$ was added and the product extracted with DCM $(2 \times 250 \mathrm{~mL})$. The combined organic layers were washed with water $(2 \times 250 \mathrm{~mL})$, dried over anhydrous sodium sulfate and concentrated under reduced pressure to yield amide product $(9.0 \mathrm{~g})$ as a red gum. To a degassed solution of tert-butyl (5-bromo-2-methoxypyridin-3-yl)carbamate (7.0 g, $23.1 \mathrm{mmol})$, amide product $(5.36 \mathrm{~g}, 23.1 \mathrm{mmol})$ and cesium carbonate $(22.57 \mathrm{~g}, 69.3 \mathrm{mmol})$ in 1,4dioxane $(100 \mathrm{~mL})$ stirred under argon, was added RuPhos $(4.31 \mathrm{~g}, 9.2 \mathrm{mmol})$ and $\operatorname{Pd}_{2}(\mathrm{dba})_{3}(4.23 \mathrm{~g}, 4.6$ $\mathrm{mmol})$. The reaction was stirred at $100{ }^{\circ} \mathrm{C}$ for $16 \mathrm{~h}$ in a sealed vessel. Water $(200 \mathrm{~mL})$ was added and the product extracted with ethyl acetate $(200 \mathrm{~mL})$. The organic layer was dried over anhydrous sodium 
sulfate and concentrated under reduced pressure to yield the crude product as a brown liquid. This was purified by column chromatography on silica using a $0-20 \%$ ethyl acetate in hexane gradient. The appropriate fraction were combined and concentrated under reduced pressure to yield the title compound ( $2.50 \mathrm{~g}, 22 \%$ yield) as yellow gum. ${ }^{1} \mathrm{H}$ NMR (400 MHz, DMSO- $\left.d_{6}\right) \delta \mathrm{ppm} 1.50(\mathrm{~s}, 9 \mathrm{H})$, 2.75-2.86 (m, 2 H), 2.91 (s, 3 H), 3.63-3.69 (m, 2 H), 4.02 (s, 3 H), 4.31-4.37 (m, 2 H), 5.04-5.21 (m, 3 H), 6.68 (br. s., $1 \mathrm{H}), 6.78$ (dd, $J=8.1,1.8 \mathrm{~Hz}, 1 \mathrm{H}), 6.82$ (d, $J=8.2 \mathrm{~Hz}, 1 \mathrm{H}), 6.99$ (s, $1 \mathrm{H}), 7.69$ (d, $J$ $=2.4 \mathrm{~Hz}, 1 \mathrm{H}$ ), 8.25 (br. s., $1 \mathrm{H})$; LCMS (Method F): $\mathrm{MH}^{+}\left(\mathrm{C}_{24} \mathrm{H}_{31} \mathrm{~N}_{4} \mathrm{O}_{5}\right)$ mass required: 455 mass found: 455, Rt 4.93 min, $92 \%$ by UV.

\section{$N$-allyl-4-(5-amino-6-methoxypyridin-3-yl)- $N$-methyl-3,4-dihydro- $2 H$-benzo[b][1,4]oxazine-6- carboxamide, 57}<smiles>C=CCN(C)C(=O)c1ccc2c(c1)N(c1cnc(OC)c(N)c1)CCO2</smiles>

To a solution of tert-butyl (5-(6-(allyl(methyl)carbamoyl)-2H-benzo[b][1,4]oxazin-4(3H)-yl)-2methoxypyridin-3-yl)carbamate $(4 \mathrm{~g}, 8.80 \mathrm{mmol})$ in DCM $(100 \mathrm{~mL})$, was added trifluoracetic acid (3.4 $\mathrm{mL}, 44.0 \mathrm{mmol})$. The reaction was stirred for $16 \mathrm{~h}$. The solvent was concentrated under reduced pressure, saturated sodium bicarbonate solution $(50 \mathrm{~mL})$ was added and extracted with DCM $(2 \times 50$ $\mathrm{mL}$ ). The combined organic portions were dried over anhydrous sodium sulfate and concentrated under reduced pressure to yield the crude product. This was purified by column chromatography on silica using a 0-40\% ethyl acetate in cyclohexane. The appropriate fractions were combined and concentrated under reduced pressure to yield the title compound $(2.5 \mathrm{~g}, 79 \%)$ as a yellow gum. ${ }^{1} \mathrm{H} \mathrm{NMR}(400 \mathrm{MHz}$, $\left.\mathrm{CDCl}_{3}\right) \delta$ ppm 2.92 (br. s., $3 \mathrm{H}$ ), 3.59-3.64 (m, 2 H), 3.75-3.86 (m, 2 H), 4.00 (s, $\left.3 \mathrm{H}\right), 4.29-4.38$ (m, 2 H), 5.06-5.33 (m, 3 H), 6.70 (br. s, 1 H), 6.77 (dd, $J=8.3,2.2 \mathrm{~Hz}, 1 \mathrm{H}), 6.80$ (d, $J=2.2 \mathrm{~Hz}, 1 \mathrm{H}), 6.82$ $(\mathrm{d}, J=8.3 \mathrm{~Hz}, 1 \mathrm{H}), 7.46(\mathrm{~d}, J=2.2 \mathrm{~Hz}, 1 \mathrm{H})$; LCMS (Method E): $\mathrm{MH}^{+}\left(\mathrm{C}_{19} \mathrm{H}_{23} \mathrm{~N}_{4} \mathrm{O}_{3}\right)$ mass required: 355 mass found: 355 , Rt 1.89 min, $98 \%$ by UV. 
<smiles>C=CCN(C)C(=O)c1ccc2c(c1)N(c1cnc(OC)c(NS(=O)(=O)CC=C)c1)CCO2</smiles>

To a solution of $N$-allyl-4-(5-amino-6-methoxypyridin-3-yl)- $N$-methyl-3,4-dihydro- $2 H$ benzo[b][1,4]oxazine-6-carboxamide $(2.0 \mathrm{~g}, 5.6 \mathrm{mmol})$ and pyridine $(1.34 \mathrm{~mL}, 16.9 \mathrm{mmol})$ in acetonitrile $(40 \mathrm{~mL})$, was added prop-2-ene-1-sulfonyl chloride $(1.19 \mathrm{~g}, 8.5 \mathrm{mmol})$. The reaction was stirred at $70{ }^{\circ} \mathrm{C}$ for $16 \mathrm{hr}$. The mixture was then concentrated under reduced pressurea and the residue purified by column chromatography on silica using a $0-40 \%$ ethyl acetate in cyclohexane gradient. The appropriate fractions were combined and concentrated under reduced pressure to yield the title compound $(1.8 \mathrm{~g}, 69 \%)$ as a yellow gum. ${ }^{1} \mathrm{H}$ NMR (400 MHz, DMSO- $\left.d_{6}\right) \delta \mathrm{ppm} 2.93(\mathrm{~s}, 3 \mathrm{H}), 3.57-$ 3.74 (m, 2 H), 3.82 (d, J = 7.3 Hz, 2 H), 4.01 (s, 3 H), 4.24-4.42 (m, 2 H), 5.08-5.21 (m, 2 H), 5.32 (dd, $J=17.1,0.9 \mathrm{~Hz}, 1 \mathrm{H}), 5.44(\mathrm{~d}, J=10.0 \mathrm{~Hz}, 1 \mathrm{H}), 5.66-5.81(\mathrm{~m}, 1 \mathrm{H}), 5.87(\mathrm{ddt}, J=17.1,10.0,7.3 \mathrm{~Hz}$, $1 \mathrm{H}), 6.73-6.86(\mathrm{~m}, 3 \mathrm{H}), 7.73(\mathrm{~d}, J=2.4 \mathrm{~Hz}, 1 \mathrm{H}), 7.83(\mathrm{~d}, J=2.4 \mathrm{~Hz}, 1 \mathrm{H})$; LCMS (Method D): $\mathrm{MH}^{+}$ $\left(\mathrm{C}_{22} \mathrm{H}_{27} \mathrm{~N}_{4} \mathrm{O}_{5} \mathrm{~S}\right)$ mass required: 458 mass found: 458 , Rt min, $80 \%$ by $\mathrm{UV}$.

\section{9-methoxy-2-oxa-12-thia-5,8,11,17-tetraazatetracyclo[17.2.2.16,10,0(20,5)]tetracosa-} 1(21),6(24),7,9,14,19,22-heptaen-18-one 12,12-dioxide, 59<smiles></smiles>

To a solution of $\mathrm{N}$-allyl-4-(5-(allylsulfonamido)-6-methoxypyridin-3-yl)- $\mathrm{N}$-methyl-3,4-dihydro- $\mathrm{H}$ benzo[b][1,4]oxazine-6-carboxamide $(1.00 \mathrm{~g}, 2.18 \mathrm{mmol})$ in DCM $(100 \mathrm{~mL})$ degassed for $30 \mathrm{~min}$, was added Grubbs second generation catalyst $(0.370 \mathrm{~g}, 0.44 \mathrm{mmol})$. The reaction was stirred at $40{ }^{\circ} \mathrm{C}$ for $16 \mathrm{~h}$. The mixture was filtered through celite, washed with DCM $(20 \mathrm{~mL})$ and the filterate was concentrated under reduced pressure to yield the crude product $(1.00 \mathrm{~g})$ as a black solid. This was purified by column chromatography on silica using a 0-2\% methanol in DCM gradient. The appropriate fractions were combined and concentrated under reduced pressure to yield the title compound $(800 \mathrm{mg}$, $63 \%)$ as an off white solid. ${ }^{1} \mathrm{H}$ NMR (400 MHz, DMSO- $\left.d_{6}\right) \delta$ ppm $2.94(\mathrm{~s}, 3 \mathrm{H}), 3.69-3.74(\mathrm{~m}, 2 \mathrm{H})$, 
3.88-3.96 (m, 2 H), 4.02 (s, 3 H), 4.04-4.08 (m, 2 H), 4.39-4.43 (m, 2 H), 5.67-5.77 (m, 1 H), 5.86 (dt, $J=15.8,3.5 \mathrm{~Hz}, 1 \mathrm{H}), 6.51(\mathrm{~d}, J=1.8 \mathrm{~Hz}, 1 \mathrm{H}), 6.84(\mathrm{dd}, J=8.1,1.8 \mathrm{~Hz}, 1 \mathrm{H}), 6.89$ (br. s., $1 \mathrm{H})$, $6.89(\mathrm{~d}, J=8.1 \mathrm{~Hz}, 1 \mathrm{H}), 7.64(\mathrm{~d}, J=2.4 \mathrm{~Hz}, 1 \mathrm{H}), 7.72(\mathrm{~d}, J=2.4 \mathrm{~Hz}, 1 \mathrm{H})$; LCMS (Method E): $\mathrm{MH}^{+}$ $\left(\mathrm{C}_{20} \mathrm{H}_{23} \mathrm{~N}_{4} \mathrm{O}_{5} \mathrm{~S}\right)$ mass required: 431 mass found: 431 , Rt $1.73 \mathrm{~min}, 85 \%$ by $\mathrm{UV}$.

\section{9-Methoxy-17-methyl-2-oxa-12-thia-5,8,11,17-tetraazatetracyclo[17.2.2.16,10,0(20,5)]tetracosa-} 1(21),6(24),7,9,19,22-hexaen-18-one 12,12-dioxide, 25<smiles>COc1ccc(N2CCOc3ccc(C(=O)N(C)CCCCS(=O)(=O)Nc4ccncc4)cc32)cn1</smiles>

To a solution of 9-methoxy-2-oxa-12-thia-5,8,11,17-tetraazatetracyclo[17.2.2.16,10,0(20,5)]tetracosa1(21),6(24),7,9,14,19,22-heptaen-18-one 12,12-dioxide (1.30 g, $3.0 \mathrm{mmol})$ and methanol (30 mL),was added palladium on carbon $(0.32 \mathrm{~g}, 0.30 \mathrm{mmol})$ under a nitrogen atmosphere. The reaction was conducted in Parr Shaker Hydrogenation Apparatus at 40 Psi for $3 \mathrm{~h}$. The mixture was then filtered through celite, washed with methanol $(30 \mathrm{~mL})$ and the filterate concentrated under reduced pressure to yield crude product $(1.1 \mathrm{~g})$. This was purified by column chromatography on silica using at $0-2 \%$ methanol in DCM gradient. The appropriate fractions were combined and concentrated under reduced pressure to yield the title compound ( $800 \mathrm{mg}, 1.77 \mathrm{mmol}, 59 \%)$ as an off-white solid. ${ }^{1} \mathrm{H}$ NMR (400 MHz, DMSO- $d_{6}$ ) $\delta$ ppm 1.55 (br. s., 4 H), 2.81 (s, 3 H), 3.13-3.28 (m, 4 H), 3.67-3.73 (m, 2 H), 3.91 (s, $3 \mathrm{H}), 4.30-4.36(\mathrm{~m}, 2 \mathrm{H}), 6.31(\mathrm{~d}, J=2.0 \mathrm{~Hz}, 1 \mathrm{H}), 6.62(\mathrm{dd}, J=8.1,2.0 \mathrm{~Hz}, 1 \mathrm{H}), 6.84(\mathrm{~d}, J=8.1$ $\mathrm{Hz}, 1 \mathrm{H}), 7.61(\mathrm{~d}, J=2.4 \mathrm{~Hz}, 1 \mathrm{H}), 7.90(\mathrm{~d}, J=2.4 \mathrm{~Hz}, 1 \mathrm{H}), 9.16(\mathrm{~s}, 1 \mathrm{H}) ; \mathrm{LCMS}$ (Method A): $\mathrm{MH}^{+}$ $\left(\mathrm{C}_{20} \mathrm{H}_{25} \mathrm{~N}_{4} \mathrm{O}_{5} \mathrm{~S}\right)$ mass required: 433 mass found: 433 , Rt 0.76 min, $96 \%$ by UV.

\section{9-Methoxy-17-methyl-2-oxa-12-thia-5,8,11,17-tetraazatetracyclo[17.2.2.16,10,0(20,5)]tetracosa-} 1(21),6(24),7,9,19,22-hexaene 12,12-dioxide, 20<smiles>COc1ccc(N2C=CC3=CC=C(OCC2)c2ccc(NS(C)(=O)=O)cc2NS(=O)(=O)CCCCN(C)C3)cn1</smiles>

To a solution of 9-methoxy-17-methyl-2-oxa-12-thia-5,8,11,17-tetraazatetracyclo [17.2.2.16,10,0(20,5)]tetracosa-1(21),6(24),7,9,19,22-hexaen-18-one 12,12-dioxide (200 mg, 0.46 $\mathrm{mmol})$ in THF $(10 \mathrm{~mL})$ was added borane dimethylsulfide complex (1 M in THF, $1.85 \mathrm{~mL}, 1.85 \mathrm{mmol})$. 
The reaction was then stirred at $70{ }^{\circ} \mathrm{C}$ for $16 \mathrm{hr}$. Methanol $(4 \mathrm{~mL})$ was added and the mixture heated at reflux for $16 \mathrm{~h}$. The mixture was then concentrated under reduced pressure, quenched with water and extracted with ethyl acetate $(2 \times 10 \mathrm{~mL})$. The combined organic layers were dried over anhydrous sodium sulfate and concentrated under reduced pressure to yield the crude product as yellow gum. This was then purified by preparative HPLC on an XTerra column using $40 \% 5 \mathrm{mM}$ ammonium bicarbonate in acetonitrile. The appropriate fractions were combined and the solvent removed under reduced pressure to yield the title compound $\left(33 \mathrm{mg}, 16 \%\right.$ ) as an off-white solid. ${ }^{1} \mathrm{H}$ NMR (400 MHz, DMSO$\left.d_{6}\right) \delta$ ppm $1.44-1.51(\mathrm{~m}, 2 \mathrm{H}), 1.83-1.92(\mathrm{~m}, 2 \mathrm{H}), 2.16$ (s, $\left.3 \mathrm{H}\right), 2.24-2.30$ (m, $\left.2 \mathrm{H}\right), 3.20$ (s, $\left.2 \mathrm{H}\right)$, 3.29-3.35 (m, 2 H), 3.66-3.71 (m, 2 H), 4.03 (s, 3 H), 4.31-4.38 (m, 2 H), 6.48 (dd, J = 8.0, 1.5 Hz, 1 H), $6.66(\mathrm{~d}, J=1.5 \mathrm{~Hz}, 1 \mathrm{H}), 6.74(\mathrm{~d}, J=8.0 \mathrm{~Hz}, 1 \mathrm{H}), 7.67$ (d, $J=2.4 \mathrm{~Hz}, 1 \mathrm{H}), 7.69$ (d, $J=2.4 \mathrm{~Hz}, 1$ $\mathrm{H}$ ); LCMS (Method A): $\mathrm{MH}^{+}\left(\mathrm{C}_{20} \mathrm{H}_{27} \mathrm{~N}_{4} \mathrm{O}_{4} \mathrm{~S}\right)$ mass required: 419 mass found: 419, Rt 0.59 min, $97 \%$ by UV. 


\section{Assay Data}

Table 1: Supporting information for PI3Kd enzyme data (standard deviation and N numbers):

\begin{tabular}{|c|c|c|c|}
\hline Cpd No & PI3K $\delta$ PIC50 MEAN & PI3K & $\mathbf{N}$ \\
\hline 2 & 5.6 & 0.28 & 4 \\
\hline 3 & 5.9 & 0.32 & 3 \\
\hline 4 & 6.2 & 0.17 & 3 \\
\hline 5 & 6.8 & 0.12 & 3 \\
\hline 6 & 5.1 & 0.28 & 5 \\
\hline 7 & 5.9 & 0.27 & 4 \\
\hline 8 & 6.6 & 0.14 & 3 \\
\hline 9 & 7.4 & 0.24 & 3 \\
\hline 10 & 6.4 & 0.25 & 3 \\
\hline 11 & 7.2 & 0.16 & 3 \\
\hline 12 & 5.8 & 0.21 & 4 \\
\hline 13 & 4.9 & 0.27 & 3 \\
\hline 14 & 5.2 & 0.1 & 6 \\
\hline 15 & 6.2 & 0.45 & 4 \\
\hline 16 & 5.8 & 0.15 & 3 \\
\hline 17 & 7 & 0.16 & 2 \\
\hline 20 & 7.1 & 0.26 & 3 \\
\hline 21 & 7.3 & 0.19 & 3 \\
\hline 22 & 7.8 & 0.01 & 2 \\
\hline 23 & 5.5 & 0.23 & 4 \\
\hline 24 & 6.9 & 0.12 & 3 \\
\hline 25 & 6.3 & 0.4 & 3 \\
\hline
\end{tabular}


Table 2: Supporting information for full profiling of Cpds 18 and 19:

\begin{tabular}{|l|c|c|c|c|c|c|}
\hline & \multicolumn{3}{|c|}{ Compound 18 } & \multicolumn{3}{c|}{ Compound 19 } \\
\hline & $\begin{array}{c}\text { PIC50 } \\
\text { MEAN }\end{array}$ & $\begin{array}{c}\text { PIC50 } \\
\text { STDDEV }\end{array}$ & N & $\begin{array}{c}\text { PIC50 } \\
\text { MEAN }\end{array}$ & $\begin{array}{c}\text { PIC50 } \\
\text { STDDEV }\end{array}$ & N \\
\hline PI3K $\delta$ & 6.2 & 0.12 & 4 & 7.7 & 0.1 & 3 \\
\hline PI3K $\boldsymbol{\alpha}$ & 4.9 & 0.23 & 3 & 5.6 & 0.25 & 3 \\
\hline PI3K $\beta$ & 5.1 & 0.09 & 4 & 5.9 & 0.16 & 3 \\
\hline PI3K $\gamma$ & 4.6 & & 1 & 5.8 & 0.32 & 3 \\
\hline IFN $\gamma$ stimulated & 5.8 & 0.51 & 3 & 6.5 & 0.29 & 3 \\
\hline cytostim whole blood & & & & & & \\
\hline
\end{tabular}




\section{Conformational Search}

Unconstrained Conformational Search of Progenitor 18 (Green) and Macrocycle 19 (Blue)

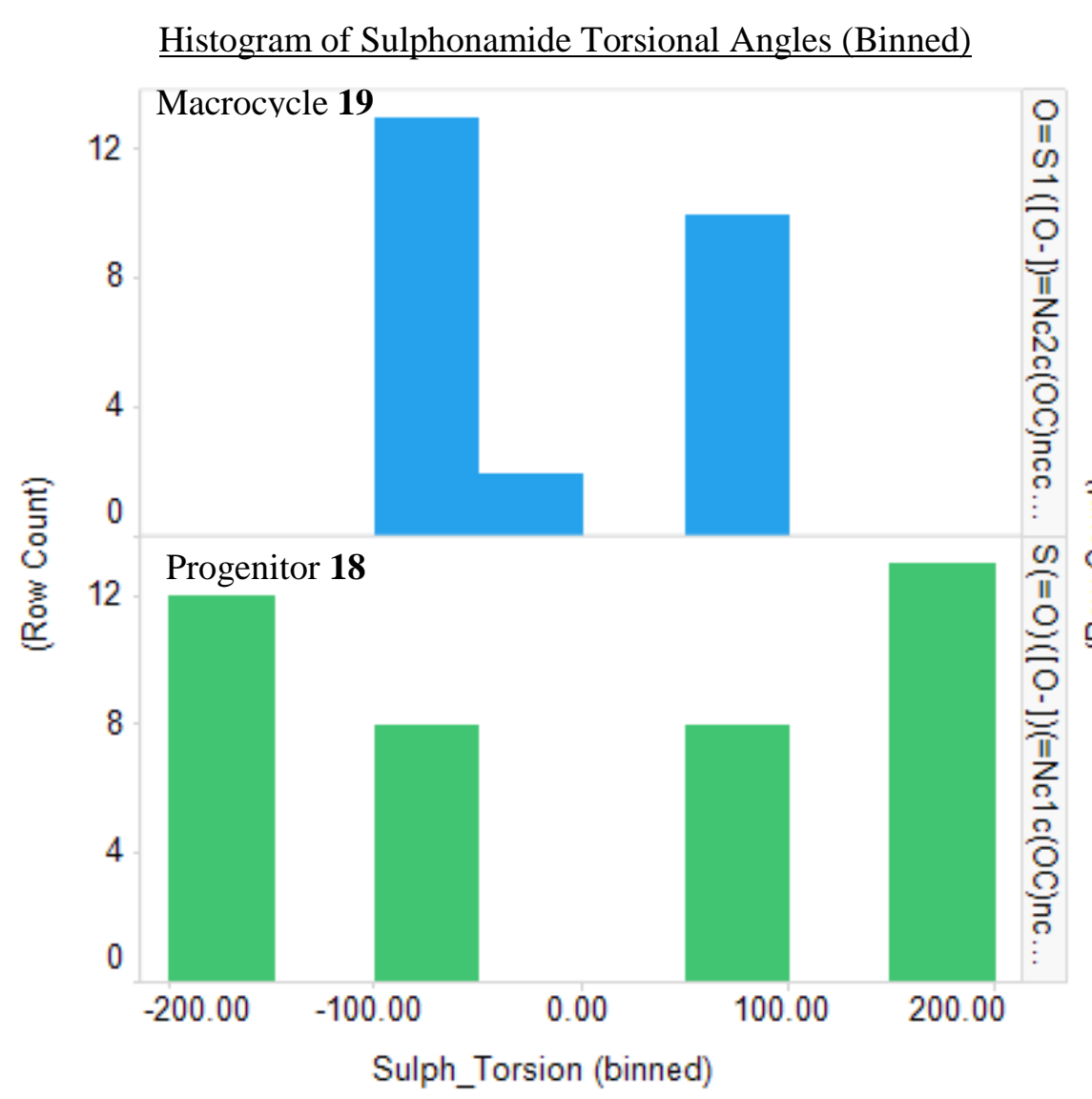

Histogram of Amine Torsional Angles (Binned)

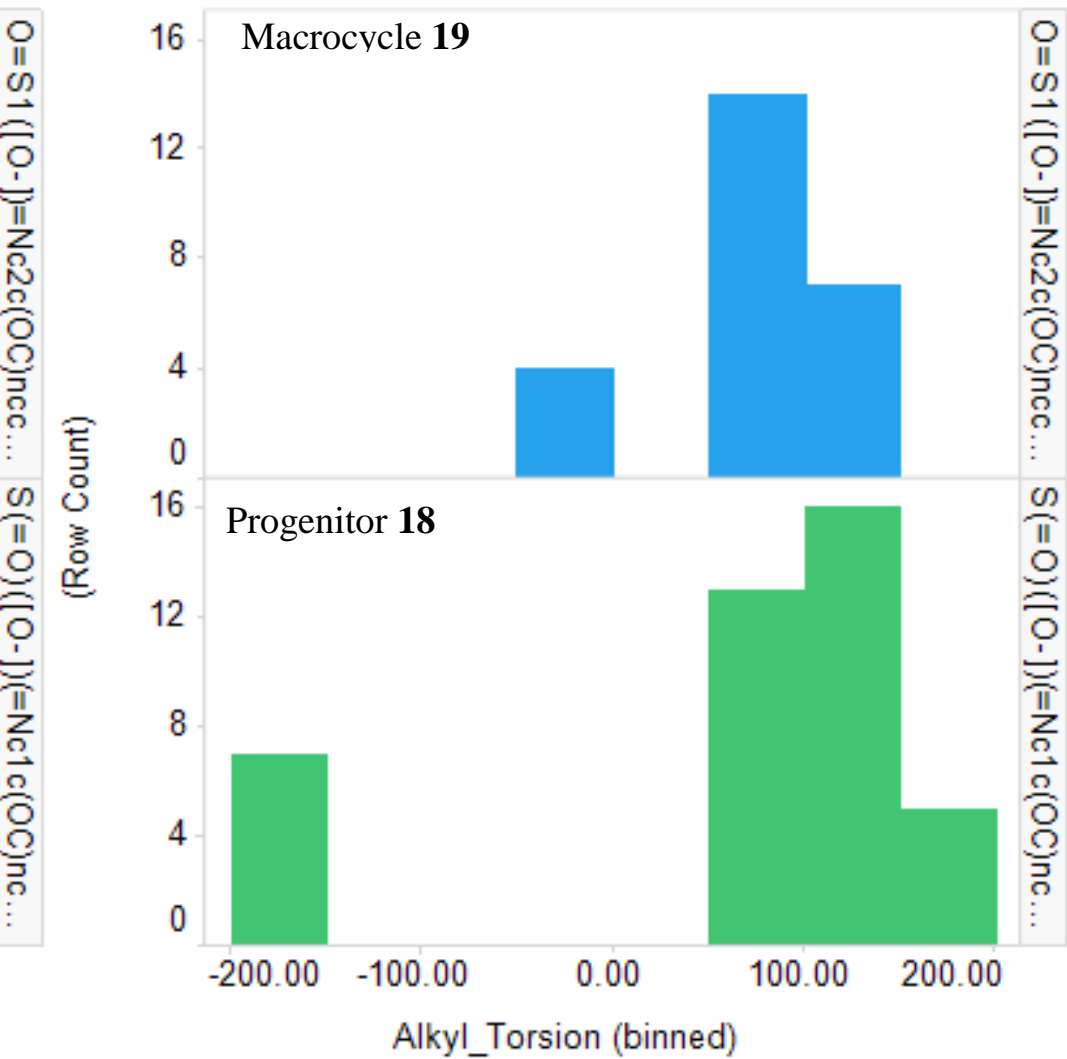




\section{SPR Data}

Table 3: Full SPR data:

\begin{tabular}{|c|c|c|c|c|c|c|c|c|c|}
\hline Entry & Compound & $\begin{array}{c}\Delta \mathrm{H} / \\
\mathrm{kJ} \mathrm{mol}^{-1}\end{array}$ & $\begin{array}{c}\text { Error } \Delta \mathrm{H} / \\
\mathrm{kJ} \mathrm{mol}^{-1}\end{array}$ & $\begin{array}{c}\Delta \mathrm{S} / \mathrm{J} \mathrm{K}^{-1} \\
\mathrm{~mol}^{-1}\end{array}$ & $\begin{array}{c}\text { Error } \Delta \mathrm{S} / \mathrm{J} \\
\mathrm{K}^{-1} \mathrm{~mol}^{-1}\end{array}$ & $\begin{array}{c}\Delta \mathrm{G} 25^{\circ} \mathrm{C} / \\
\mathrm{kJ} \mathrm{mol}^{-1}\end{array}$ & $\begin{array}{c}\mathrm{pK}_{\mathrm{d}} \\
25^{\circ} \mathrm{C}\end{array}$ & $\mathrm{pIC}_{50}$ & $\mathrm{pK}_{\text {app }}$ \\
\hline 1 & & -55.2 & 8.0 & -59.9 & 27.6 & -37.4 & 6.6 & 6.2 & 6.8 \\
\hline 2 & & -62.5 & 4.9 & -85.0 & 17.0 & -37.1 & 6.5 & 6.2 & 6.8 \\
\hline 3 & & -1.0 & 35.8 & 163.9 & 125.3 & -49.9 & 8.7 & 7.7 & 8.3 \\
\hline 4 & & 0.3 & 5.2 & 155.8 & 18.0 & -46.1 & 8.1 & 7.7 & 8.3 \\
\hline 5 & & -27.8 & 3.1 & 49.2 & 10.6 & -42.4 & 7.4 & 6.8 & 7.4 \\
\hline 6 & $\begin{array}{l}\text { Control } \\
\text { PI3Kd inhibitol }\end{array}$ & -23.3 & 1.1 & 64.9 & 3.8 & -42.6 & 7.5 & 6.8 & 7.4 \\
\hline 7 & & -15.6 & 1.3 & 91.1 & 4.4 & -42.7 & 7.5 & 6.8 & 7.4 \\
\hline
\end{tabular}




\section{Crystallography Methods}

The protein was expressed and purified as described previously ${ }^{1}$. Crystals were grown by cocrystallisation of PI3K delta with an inhibitor previously seen to give reproducible high quality crystals using a modified version of the protocol described previously ${ }^{1}$. A $50 \mathrm{mM}$ tool compound stock solution in DMSO was prepared from which $3.5 \mu \mathrm{l}$ was mixed with $28 \mu \mathrm{l}$ of $5 \% \mathrm{w} / \mathrm{v} \mathrm{n}$-dodecyl- $\beta$-D-maltoside (DDM) prior to addition to $280 \mu \mathrm{l}$ of protein solution at $5 \mathrm{mg} / \mathrm{ml}$ (in $20 \mathrm{mM}$ Tris/ $\mathrm{HCl} \mathrm{pH} \mathrm{7.2,} 50 \mathrm{mM}$ ammonium sulphate, $5 \mathrm{mM}$ dithiothreitol, $1 \%$ ethylene glycol, $1 \%$ betaine, $0.02 \% \mathrm{CHAPS})$. The mixture was incubated at room temperature for $60 \mathrm{~min}$ and then spun at $4^{\circ} \mathrm{C}$ for $15 \mathrm{~min}$. A crystal seeding solution was made by transferring an existing PI3K delta crystal into $5 \mu \mathrm{l}$ of Morpheus screen (Molecular Dimensions Ltd) condition G2 (0.1 M buffer system 1 pH 6.5, $0.1 \mathrm{M}$ carboxylic acids, 30\% ethylene glycol/PEG 8000). The crystal was crushed and added to $1 \mathrm{ml}$ of Morpheus screen condition G2 and vortexed vigorously. The seed stock was typically thawed and then diluted by a factor of 20 to 40 with Morpheus screen condition G2 and then vortexed before use in the crystallisation protocol. The crystallisation was carried out by sitting drop vapour diffusion using plates prepared with a Mosquito liquid handling robot with crystallisation drops consisting of $200 \mathrm{nl}$ protein, $200 \mathrm{nl}$ well solution and $100 \mathrm{nl}$ seeding solution, using Morpheus screen condition G2 with $0 \%$ or $10 \%$ glycerol added for the well solution. Crystals were transferred for soaking to drops containing Morpheus screen condition G2 with $10 \%$ glycerol and $5 \%$ compound solution $(200 \mathrm{mM}$ compound stock solution in DMSO) added. The crystals were soaked overnight prior to flash freezing direct from the soaking drop in liquid nitrogen ready for data collection.

X-ray diffraction data were collected at $100 \mathrm{~K}$ using Pilatus-6M detectors at the Diamond Light Source and the European Synchrotron Radiation Facility, for more details see Table 4. The data were processed and scaled utilising either autoPROC ${ }^{2}$ incorporating STARANISO ${ }^{3}$, XDS $^{4}$, POINTLESS $^{5}$, AIMLESS $^{6}$ and the CCP4 suite of programs ${ }^{7}$ or XDS and POINTLESS/AIMLESS as implemented in the Diamond pipeline. Data collection statistics are given in Table 4. For compound 1 data after STARANISO treatment was used for refinement. The structures were determined using the coordinates of an isomorphous unliganded protein model (unpublished). $\operatorname{Coot}^{8}$ was used for model building and refinement was carried out with autoBUSTER ${ }^{9}$. The ligand geometry was checked using MOGUL ${ }^{10}$. The final model statistics are given in Table 1. 


\section{Accession Codes}

Coordinates have been deposited with the Protein Data Bank with accession codes 6zaa, 6zac \& 6zad and will be released immediately on publication.

\section{Acknowledgement}

The authors would like to thank members of Protein \& Cellular Sciences, MST, for protein production. 
Table 4; Crystallography data statistics

\begin{tabular}{|c|c|c|c|}
\hline & Compound 1 & Compound 18 & Compound 19 \\
\hline Data collection & 6zaa & $6 z a c$ & 6zad \\
\hline X-ray source & ESRF, id29 & DLS, 104 & DLS, 104 \\
\hline Space Group & $\mathrm{C} 2$ & $\mathrm{C} 2$ & $\mathrm{C} 2$ \\
\hline Cell Dimensions & & & \\
\hline $\mathbf{a , b , c}(\AA)$ & $140.05,64.56,115.46$ & $141.87,64.65,117.10$ & $141.43,64.48,116.66$ \\
\hline$\alpha, \beta, \gamma\left(^{\circ}\right)$ & $90.0,101.99,90.0$ & $90.0,103.15,90.0$ & $90.0,103.03,90.0$ \\
\hline $\begin{array}{l}\text { Processing } \\
\text { Anisotropic, used for } \\
\text { refinement }\end{array}$ & $\begin{array}{l}\text { AutoPROC (1.1.7) with } \\
\text { STARANISO }\end{array}$ & $\begin{array}{l}\text { XDS/aimless as } \\
\text { implemented at } \\
\text { Diamond }\end{array}$ & $\begin{array}{l}\text { XDS/aimless as } \\
\text { implemented at } \\
\text { Diamond }\end{array}$ \\
\hline Resolution $(\AA ̊)$ & $\begin{array}{l}68.499-2.532 \\
(2.711-2.532)\end{array}$ & $\begin{array}{l}49.90-2.15 \\
(2.21-2.15)\end{array}$ & $\begin{array}{l}34.45-2.24 \\
(2.30-2.24)\end{array}$ \\
\hline $\mathbf{R}_{\text {merge }}{ }^{b}$ & $0.054(0.878)$ & $0.048(0.750)$ & $0.069(0.767)$ \\
\hline $\mathrm{CC}(1 / 2)$ & $0.999(0.472)$ & & $0.998(0.671)$ \\
\hline Mean $I / \sigma$ & $12.6(1.4)$ & $16.0(1.8)$ & $12.1(2.1)$ \\
\hline $\begin{array}{l}\text { Completeness } \\
\text { (spherical) (\%) }\end{array}$ & $78.0(21.3)$ & $99.0(98.7)$ & $98.9(99.8)$ \\
\hline $\begin{array}{l}\text { Completeness } \\
\text { (ellipsoidal) }(\%)\end{array}$ & $92.5(60.9)$ & & \\
\hline Redundancy & $3.4(3.5)$ & $3.4(3.5)$ & $3.3(3.4)$ \\
\hline No. Reflections & $89263(4665)$ & $189192(14155)$ & 162098 (12557) \\
\hline $\begin{array}{l}\text { No. Unique } \\
\text { Reflections }\end{array}$ & 26465 (1323) & $55761(4056)$ & 48957 (3683) \\
\hline Refinement & & & \\
\hline
\end{tabular}




\begin{tabular}{|c|c|c|c|}
\hline Programme used & BUSTER 2.11 .7 & BUSTER 2.11 .7 & BUSTER 2.11.7 \\
\hline Resolution $(\AA)$ & $68.50-2.52$ & $42.97-2.15$ & $32.24-2.24$ \\
\hline $\mathbf{R}_{\text {work }} / \mathbf{R}_{\text {free }}$ & $0.184 / 0.259$ & $0.178 / 0.210$ & $0.175 / 0.214$ \\
\hline No. Reflections & 26470 & 55759 & 48949 \\
\hline $\begin{array}{l}\text { Completeness in } \\
\text { range }\end{array}$ & 77.3 & 98.8 & 98.8 \\
\hline No. atoms & & & \\
\hline Protein & 6913 & 6957 & 6948 \\
\hline Ligand & 33 & 27 & 27 \\
\hline Water & 115 & 538 & 300 \\
\hline B-factors & & & \\
\hline Protein & 97.150 & 61.557 & 63.130 \\
\hline Ligand & 56.685 & 42.528 & 41.348 \\
\hline Water & 70.900 & 62.304 & 61.130 \\
\hline R.m.s deviations & & & \\
\hline Bond lengths $(\stackrel{\AA}{\mathbf{A}})$ & 0.010 & 0.010 & 0.010 \\
\hline Bond angles $\left(^{\circ}\right)$ & 1.12 & 1.00 & 1.04 \\
\hline $\begin{array}{l}\text { Fo-Fc omit map } \\
\text { using final refined } \\
\text { co-ordinates, } \\
\text { contoured at } \\
\text { 3rms. }\end{array}$ & & & \\
\hline
\end{tabular}




\section{References}

1. Down, K.; Amour, A.; Baldwin, I. R.; Cooper, A. W. J.; Deakin, A. M.; Felton, L. M.; Guntrip, S. B.; Hardy, C.; Harrison, Z. A.; Jones, K. L.; Jones, P.; Keeling, S. E.; Le, J.; Livia, S.; Lucas, F.; Lunniss, C. J.; Parr, N. J.; Robinson, E.; Rowland, P.; Smith, S.; Thomas, D. A.; Vitulli, G.; Washio, Y.; Hamblin, J. N., Optimization of Novel Indazoles as Highly Potent and Selective Inhibitors of Phosphoinositide 3-Kinase $\delta$ for the Treatment of Respiratory Disease. J. Med. Chem. 2015, 58 (18), 7381-7399.

2. $\quad$ Vonrhein, C.; Flensburg, C.; Keller, P.; Sharff, A.; Smart, O.; Paciorek, W.; Womack, T.; Bricogne, G., Data processing and analysis with the autoPROC toolbox. Acta Crystallogr. D 2011, 67 (4), 293-302.

3. I.J. Tickle, I. J. F., C.; Keller, P.;Paciorek, W.; Sharff, A.; Vonrhein, C.; Bricogne, G., STARANISO. Cambridge, United Kingdom: Global Phasing Ltd.: 2017.

4. $\quad$ Kabsch, W., XDS. Acta Crystallogr. D 2010, 66 (Pt 2), 125-132.

5. $\quad$ Evans, P., Scaling and assessment of data quality. Acta Crystallogr. D 2006, 62 (1), 72-82.

6. Evans, P. R.; Murshudov, G. N., How good are my data and what is the resolution? Acta Crystallogr. D 2013, 69 (7), 1204-1214.

7. Winn, M. D.; Ballard, C. C.; Cowtan, K. D.; Dodson, E. J.; Emsley, P.; Evans, P. R.; Keegan, R. M.; Krissinel, E. B.; Leslie, A. G. W.; McCoy, A.; McNicholas, S. J.; Murshudov, G. N.; Pannu, N. S.; Potterton, E. A.; Powell, H. R.; Read, R. J.; Vagin, A.; Wilson, K. S., Overview of the CCP4 suite and current developments. Acta Crystallogr. D 2011, 67 (Pt 4), 235-242.

8. Emsley, P.; Lohkamp, B.; Scott, W. G.; Cowtan, K., Features and development of Coot. Acta Crystallogr. D 2010, 66 (Pt 4), 486-501.

9. $\quad$ Bricogne, G. B., E.; Brandl, M.; Flensburg, C.; Keller, P.; Paciorek, W.; Roversi, P.; Sharff, A.; Smart, O.S.; Vonrhein C.; Womack, T.O., BUSTER version 2.11.7. Global Phasing Ltd., Cambridge, U.K.: 2014.

10. Bruno, I. J.; Cole, J. C.; Kessler, M.; Luo, J.; Motherwell, W. D. S.; Purkis, L. H.; Smith, B. R.; Taylor, R.; Cooper, R. I.; Harris, S. E.; Orpen, A. G., Retrieval of Crystallographically-Derived Molecular Geometry Information. J. Chem. Inf. Comp. Sci. 2004, 44 (6), 2133-2144. 